$\frac{27}{1-14.83}+7448$

\title{
Literature Survey of Blast and Fire Effects of Nuclear Weapons on Urban Areas
}

\author{
T. A. Reitter \\ D. B. McCallen \\ S-W. Kang
}

Prepared for Federal Emergency Management Agency,

Washington, D.C., 20472

FEMA subcontract EMW-E-0883, work unit $2561 \mathrm{C}$

Final report, June 1982

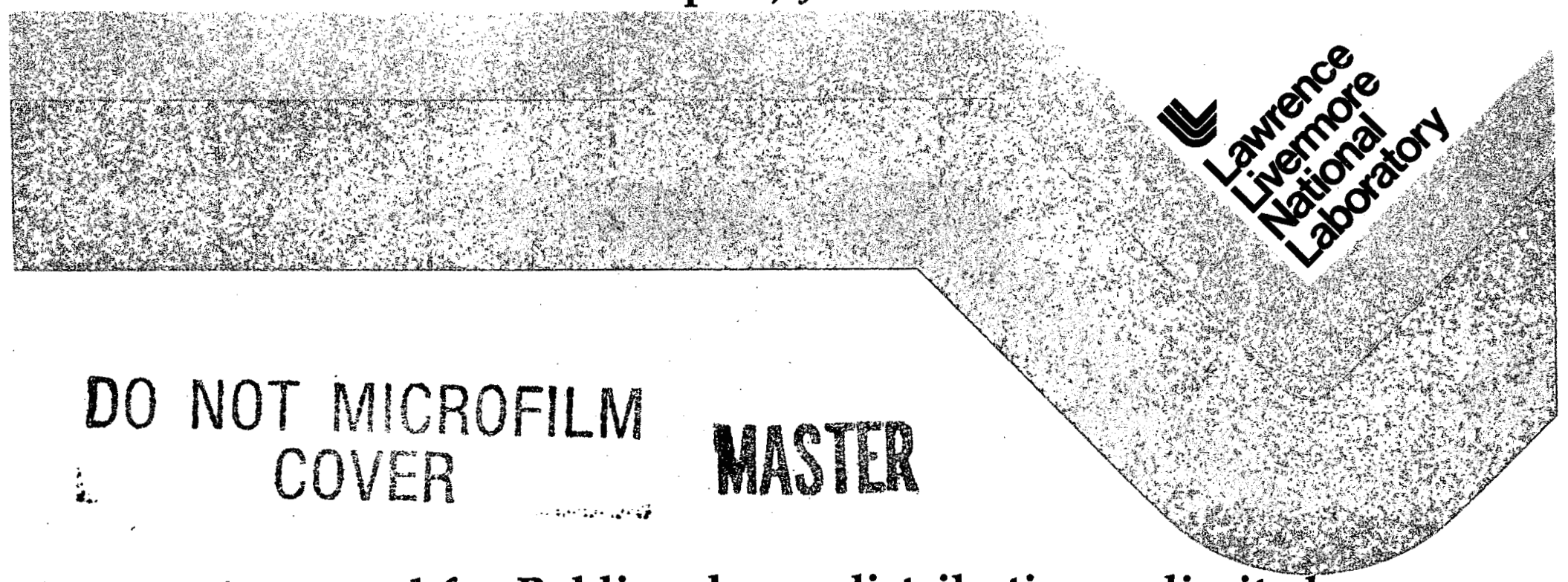

Approved for Public release: distribution unlimited 


\section{DISCLAIMER}

This report was prepared as an account of work sponsored by an agency of the United States Government. Neither the United States Government nor any agency Thereof, nor any of their employees, makes any warranty, express or implied, or assumes any legal liability or responsibility for the accuracy, completeness, or usefulness of any information, apparatus, product, or process disclosed, or represents that its use would not infringe privately owned rights. Reference herein to any specific commercial product, process, or service by trade name, trademark, manufacturer, or otherwise does not necessarily constitute or imply its endorsement, recommendation, or favoring by the United States Government or any agency thereof. The views and opinions of authors expressed herein do not necessarily state or reflect those of the United States Government or any agency thereof. 


\section{DISCLAIMER}

Portions of this document may be illegible in electronic image products. Images are produced from the best available original document. 


\title{
Literature Survey of Blast and Fire Effects of Nuclear Weapons on Urban Areas
}

\author{
T. A. Reitter \\ D. B. McCallen \\ S-W. Kang
}

Prepared for Federal Emergency Management Agency,

Washington, D.C., 20472

FEMA subcontract EMW-E-0883, work unit $2561 \mathrm{C}$

Final report: June 1982

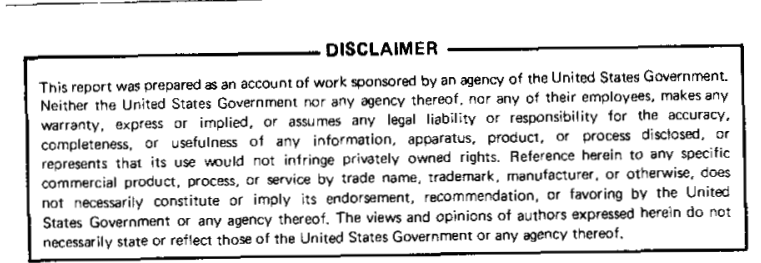

PORTIONS OF THIS REPORT ARE ILIEGTBLE. It has been reproduced from the best ava1lablo oopy to perinit the broadest possible avail-
$a b 121 t y$.

\section{LAWRENCE LIVERMORE LABORATORY \\ University of California $\bullet$ Livermore, California $\bullet 94550$}




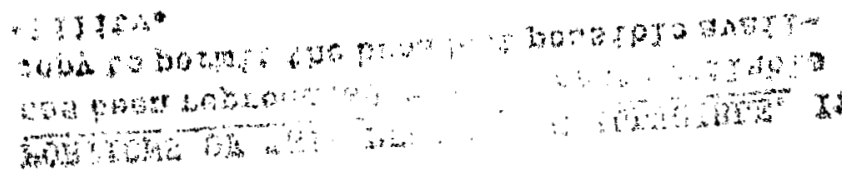

then an 


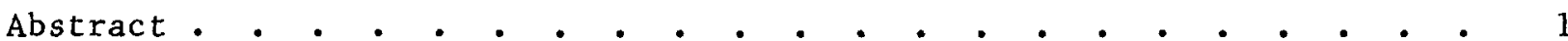
Introduction

Attack Scenario, Thermal Radiation and Blast-Wave Propagation . • . • 3

Blast-Wave Propagation • • • • • • • • • • • • • • • 4

Thermal Radiation Propagation Through the Atmosphere . . . . $\quad 8$

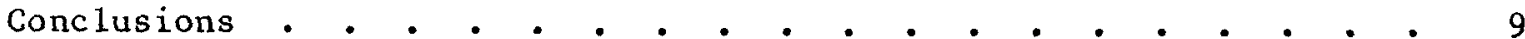

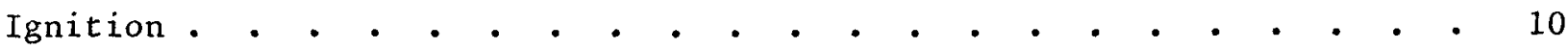

Conclusions • • • • • • • • • • • • • • • • • • •

Structural Response and Debris Formation . . . . • . • • • . • 16

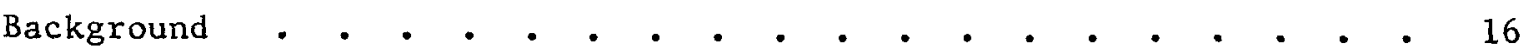

Predicting Dynamic Response of Structures • . • • • • • . $\quad$ • 19

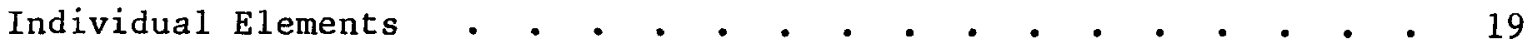

Structural Systems • • • • • • • • • • • • • • • •

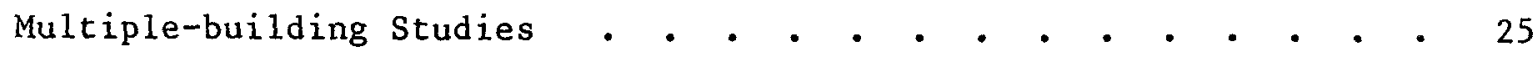

Debris Estimation • • • • • • • • • • • • • • • • . 25

Observations • • • • • • • • • • • • • • • • • •

Conclusions • • • • • • • • • • • • • • • • • •

Fire Spread • • • • • • • • • • • • • • • • • • • • • 33

Conclusions • • • • • • • • • • • • • • • • • • • 38

Conclusions . • • • • • • • • • • • • • • • • • . • • • • • 39

Appendix A. • • • • • • • • • • • • • • • • • • • • • • 40

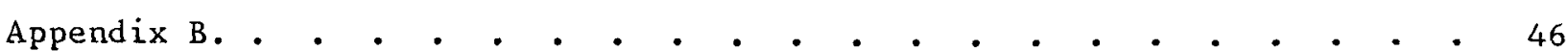


Literature Survey of Blast and Fire Effects of Nuclear Weapons on Urban Areas

T. A. Reitter

D. B. McCallen

S-W. Kang

for

Federal Emergency Management Agency Washington, D. C. 20472

Subcontract EMW-E-0883, work unit $2561 \mathrm{C}$

Final report, June 1982

Lawrence Livermore National Laboratory 7000 East Avenue

Livermore, CA 94550 
Detachable Summary

\section{Literature Survey of Blast and Fire Effects of Nuclear Weapons on Urban Areas}

The American 1iterature of the past 30 years on fire and blast effects of nuclear weapons on urban areas has been surveyed. The relevant work in the categories of thermal radiation and blast-wave propagation, ignition, structural response, and firespread is sketched and areas where information is apparently lacking are noted.

One purpose of this report is to provide entry into the literature for researchers. Over 850 references are given, arranged alphabetically by first author. Accession numbers are given wherever possible to facilitate ordering from DTIC or NTIS.

The main prupose of this report is to provide the basis for suggesting research priorities in fire and blast effects for civil defense. Sixty-two component problems are identified and assigned to one of three rankings according to their perceived relative state of knowledge. Without implying any relative importance by their order, we 1 ist below those areas where knowledge appears to be the most deficient.

- Ignition criteria for newer materials and for all materials under typical use conditions.

- Effects of complex geometry or mixed fuel on ignition criteria.

- Enclosure effects on flashover.

- Conditions under which blast promotes incipient fires.

- Effects of blast damage on the burn characteristics of structures.

- Debris production and distribution from individual building elements and buildings, especially residential.

- Fire spread rates between relatively intact structures for many simultaneous ignitions and through debris fields for various wind and weather conditions.

- Conditions for the existence of mass fires and conditions within and near them.

- Methodology for thermal radiation propagation through incompletely specified atmospheres. 
- Methodology for efficient representation of an urban area in a realistic fashion.

- Methodology for calculating shadowing and shielding effects of a specified urban area.

- Methodology for calculating dynamic response and collapse of entire buildings.

- Multiple-burst effects on thermal radiation and blast-wave loading of targets; effects of blast on established fires; and structural response of structures previously damaged by blast or fire.

Since the assignment of priorities depends on long-term goals and budget information, priorities are not suggested in this report. 


\section{ABSTRACT}

The American literature of the past 30 years on fire and blast effects of nuclear weapons on urban areas has been surveyed. The relevant work is briefly sketched and areas where information is apparently lacking are noted.

This report is intended to provide the basis for suggesting research priorities in the fire and blast effects area for the Federal Emergency Management Agency. It is also intended to provide entry into the literature for researchers. Over 850 references are given.

\section{INTRODUCTION}

The purpose of this literature survey was to determine the state of knowledge of blast and fire effects of nuclear weapons on urban areas. This information should aid the planning of research in improving predictive capabilities and the development of mitigation and hardening measures.

The awesome effects of nuclear weapons have been of paramount concern during the nearly 40 years since the destruction of Hiroshima and Nagasaki. Nuclear radiation effects have been uppermost in the public consciousness. Blast effects have figured prominently in the military thinking about nuclear weapons, probably because blast effects are the only direct effect of conventional explosives. The thermal radiation and consequent fire threat are unique features of nuclear weapons and have perhaps not received the appropriate amount of attention. This relative neglect is somewhat paradoxical in light of the enormous impact of fire during World War II.

One reason is that the difficulty of predicting fire effects, compared to blast effects, has caused them to be virtually discounted in strategic targeting. Targeting has emphasized military resources rather than population (which is more threatened by large-scale fires); consequently, fires caused by nuclear weapons have largely been the concern of civil defense planners. 
Research into blast and fire effects of interest to civil defense has been conducted for over 30 years. The directly and peripherally relevant literature is large. Because of the limited amount of time and resources available, we cannot claim to have done an exhaustive survey. Work directly relevant to our study has tended to be published only in contract reports, rather than in the technical 1iterature; such reports seldom provide an overview of the problem or references to work by those outside of the civil defense community.

The main data base used to identify relevant documents has been that of the Defense Technical Information Center (DTIC). Searches were done using keywords and authors. Since there is a significant amount of fire research in the technical journals, the Engineering Index was used also. Additional documents were identified from the references of other reports.

Previous literature surveys of the fire field have been conducted. In 1960, researchers at the Armour Research Foundation in Chicago (now the Illinois Institute of Technology Research Institute) surveyed the existing literature [S11]. In 1966 Renner, Martin, and Jones at the Naval Radiological Defense Laboratory in San Francisco did a survey of the literature in the course of identifying the important parameters in urban fire vulnerability [R09]. Martin's 1974 review [M31] on fire in nuclear warfare is a more recent overview of the fire aspect. In 1975 Hahl [H03] provided a bibliography of research funded by the Defense Civil Preparedness Agency from 1962-1975. A much broader fire bibliography has recently been prepared by Groce and McKay of SAI [G26].

This report consists of summaries of our findings in four main areas: (1) attack scenario, thermal radiation and blast wave propagation; (2) ignition; (3) structural response and debris formation; and (4) fire spread and mass fire. Conclusions are given for each section, and our overall conclusions are presented at the end. The first appendix summarizes the relative state of knowledge, while the second appendix is a bibliography of relevant documents.

We emphasize that this report presents what we perceive to be the state of knowledge in the blast and fire areas, based on the literature we were able to obtain. The more difficult question of research priorities is not addressed in this report. We hope that this document can stand alone and provide entry points to the literature for researchers. 
Studies of blast loading, fire spread and casualties resulting from the use of nuclear weapons are predicated upon a presumed attack scenario, i.e., number, yields, burst points, and timing of the weapons. There can never be certainty concerning attack scenarios. Nevertheless, useful information has been obtained from past research.

From Soviet literature available in this country, it is possible to identify the likely U.S. targets. It is also possible to make plausible guesses as to weapon yield and height of burst for any particular target or target complex. There is also sufficient information on weapon output characteristics for use in calculating fire and blast effects.

Standard works on general weapon characteristics still currently used are those of Glasstone [G12] and Brode [B73], and the DNA Weapons Effects Manual [D15] .

Some general statements can be made about Soviet attack scenarios, based on the available information concerning their arsenal and its possible use. In their 1979 publication, Douglass and Hoeber [D19] state that the most likely Soviet attack scenario is a global nuclear war employing all the resources at their command, beginning with a first strike against immediate war-fighting assets of the U.S. Both the physical and literary evidence indicates that an attack on the U.S. would use fairly large yields (0.5-1 MT), usually more than one per target; targets would be weapons, ships, command/control/communication/intelligence, political authority, etc., but not cities or population as such.

We conjecture that the most probable attack scenario would involve multiple warheads from missile-delivered re-entry vehicles. The implications of such a scenario on blast loading and fires are considerable. Most studies have been based on single-burst scenarios as a first step in the analysis of the very common post-attack phenomena. We would expect, for example, that the debris formation and fire characteristics under a multiple-burst attack would be radically different from a single-burst situation in terms of the thermal fluence, the ignition probabilities of the debris and structures, and the effect of firebrands.

Despite these uncertainties, much can be learned from consideration of a single-burst attack. We shall consider here only the blast phenomena for a 
single-burst attack scenario. Much of the blast-wave phenomena resulting from a nuclear attack is discussed in Refs. G09, B73, and D15. A useful text on blast characteristics is by Zel'dovich and Raizer [Z05].

\section{Blast-Wave Propagation}

The presence of uneven terrain, barriers or structures in the path of a blast wave causes changes in its characteristics--notably in terms of overpressure--from those corresponding to propagation over flat terrain. Rather extensive theoretical and experimental analyses have been performed on terrain effects including valley channeling, but no comprehensive theory seems to be available on barrier or structure shielding effects. While blast-wave propagation through an ideal atmosphere is well understood, there is not much information regarding the effects of humidity or dust.

In general, shock-wave interaction with inclined terrain is such that the overpressure increases upon propagation along rising slopes and decreases over falling slopes. This has been observed experimentally for small charges (see Refs. T34, W61, and K16. Correlations of these and other results have been developed as a predictive tool [A32, K25], and are called the "small-charge" method. In addition, a purely theoretical treatment of the shock-interaction processes has been made by Whitham [W35]. These two prediction methods appear to be commonly used in a priori estimates of overpressures for the case of blast propagation along inclined terrain and in valleys [W67].

In Figure 1, three schematic diagrams of the changes in shock-wave patterns caused by terrain are presented. The increase in overpressure caused by a rising slope predicted by the Whitham theory is given in Figure 2 . Typical increases of a factor of two or three are indicated; a corresponding reduction in overpressure for falling slopes is also predicted. Sample results from recent experiments to ascertain the validity of the analytical methods are shown in Figure 3. The terrain chosen consists of both rising and falling slopes in the propagation direction. Theoretical predictions for the same terrain are also shown in Figure 3. Comparison of the theory with; experiment indicates reasonable agreement along rising slopes but less satisfactory agreement along falling slopes. The comparison also demonstrates somewhat better agreement for the smal1-charge method than for the Whitham theory 

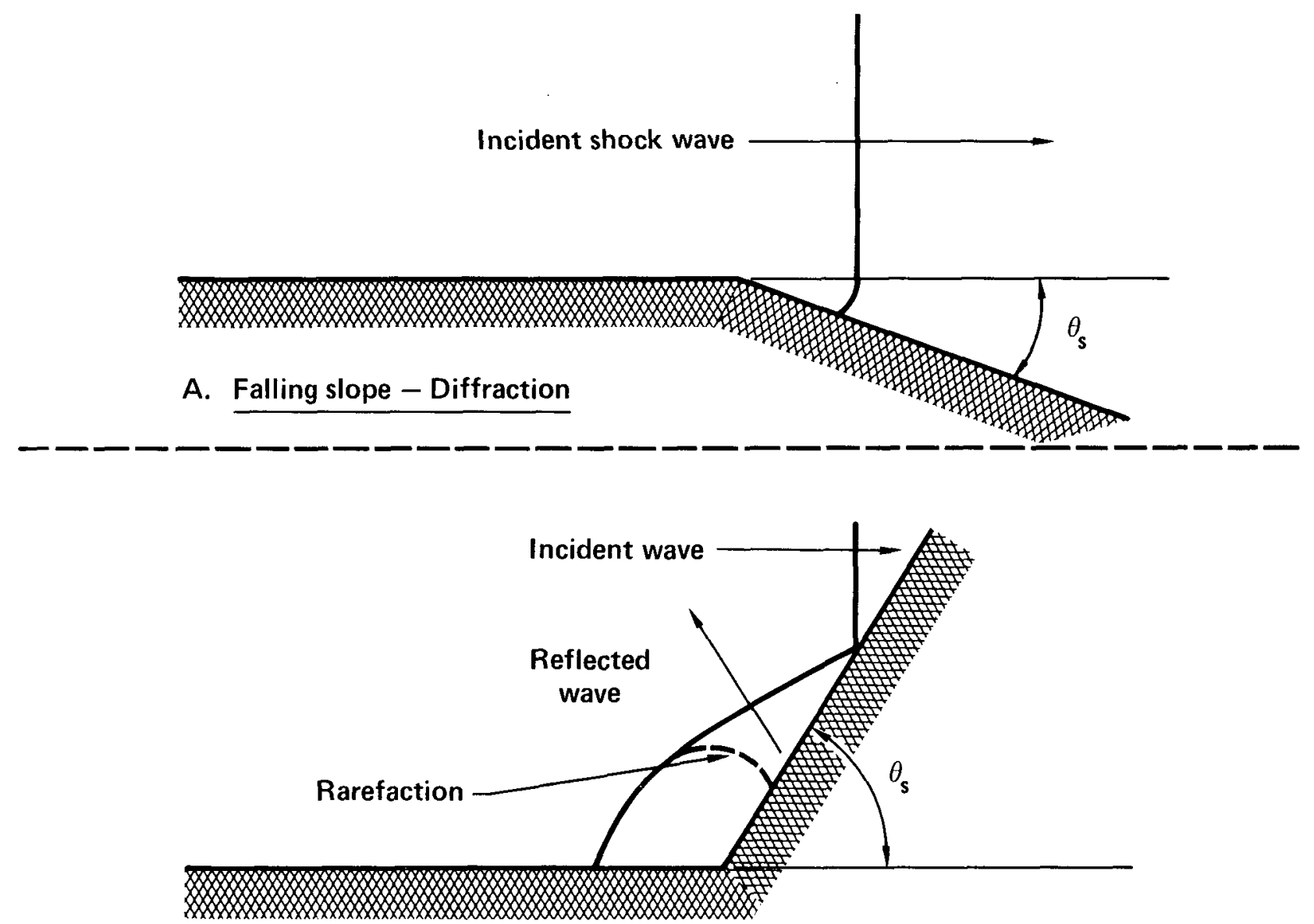

B. Rising slope - Regular reflection

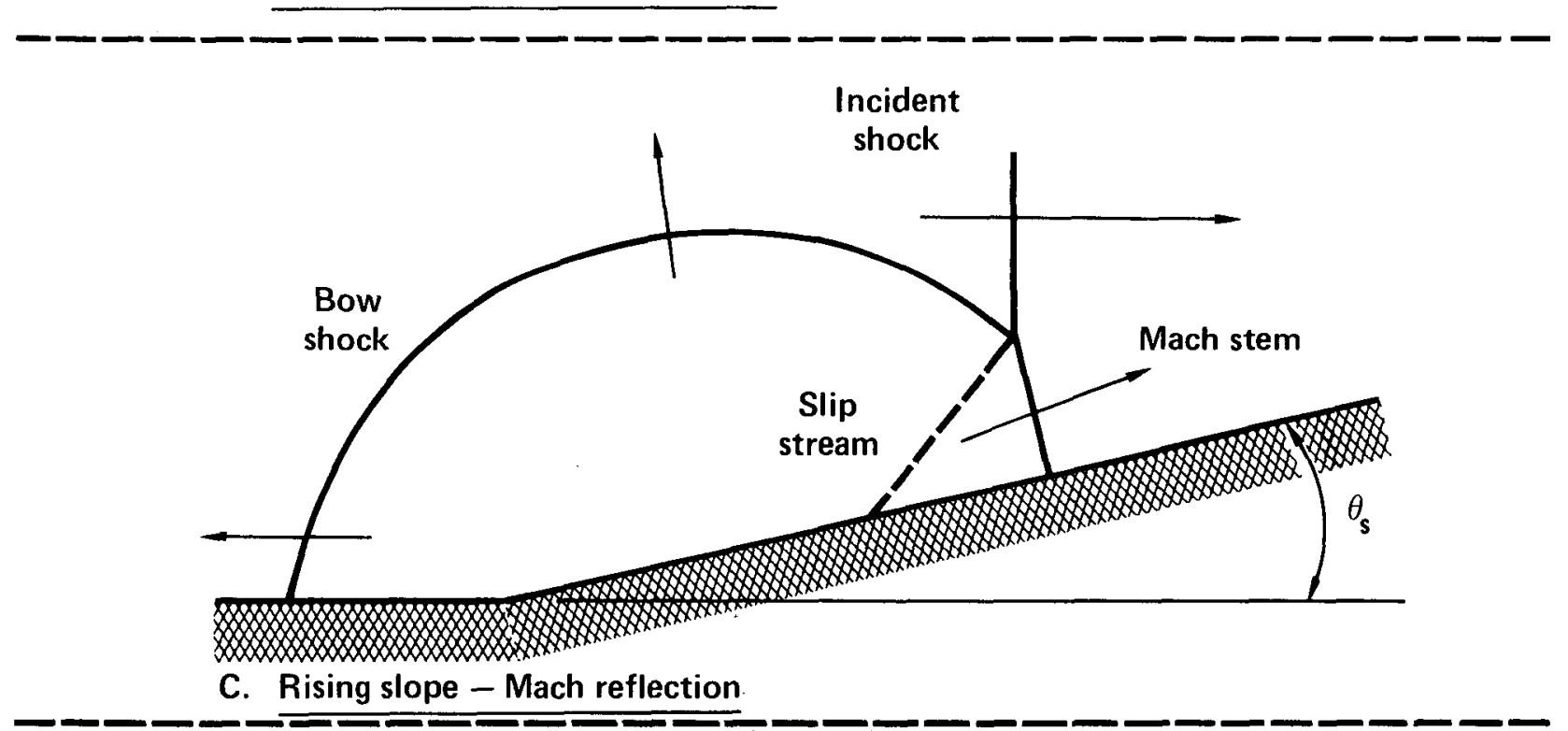

Figure 1. Changes in shock-wave patterns caused by changes in terrain (from K16). 


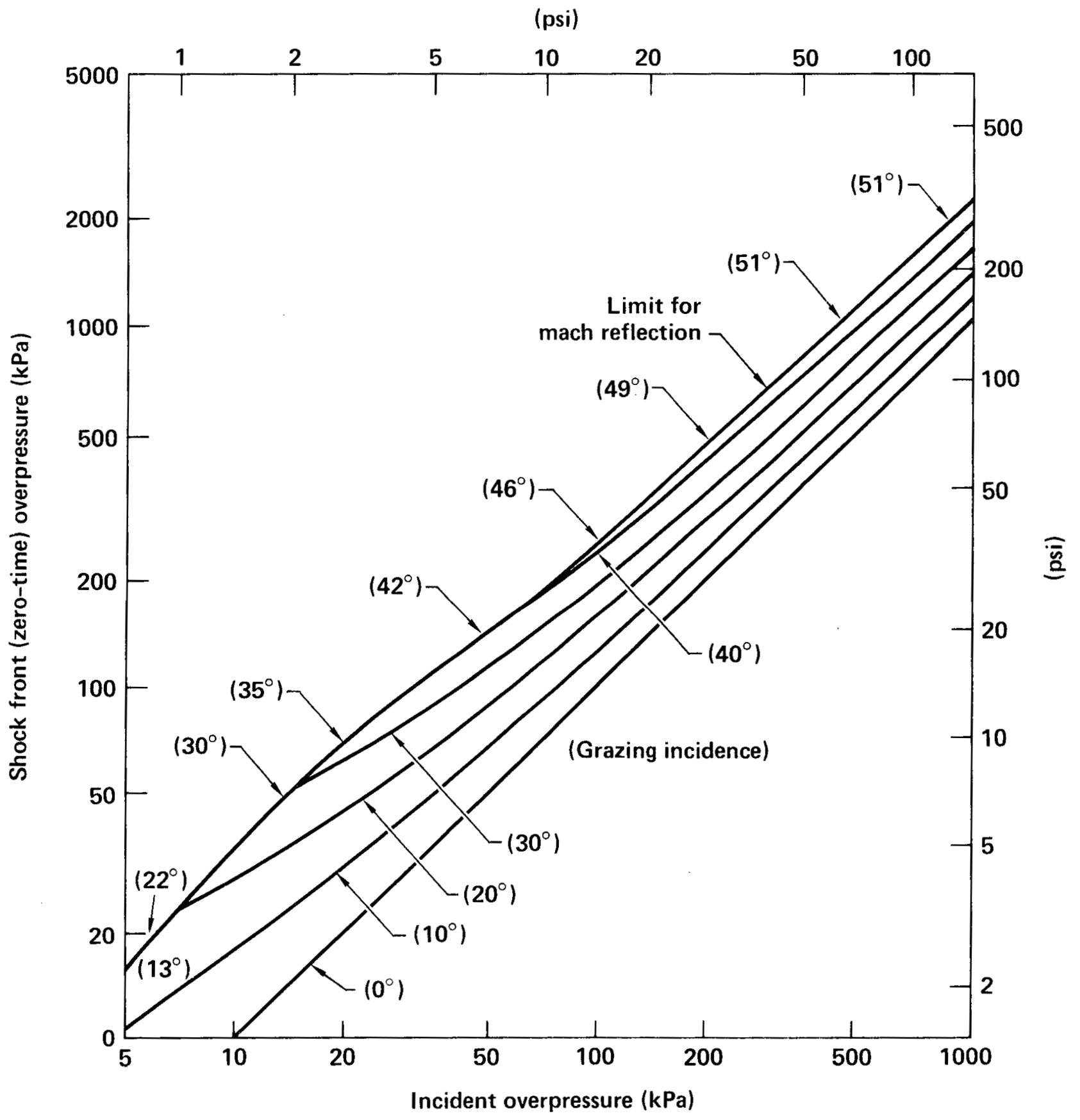

Figure 2. Overpressure at the shock front on a rising slope (reflected overpressure) vs peak incident overpressure for shock waves undergoing Mach reflection (from Whitham theory). Numbers in parentheses identify extreme (1imit) slope angles along the "limit for Mach reflection" 1 ine. Other numbers on the figure identify the slope angles to which each curve applies (from K16). 


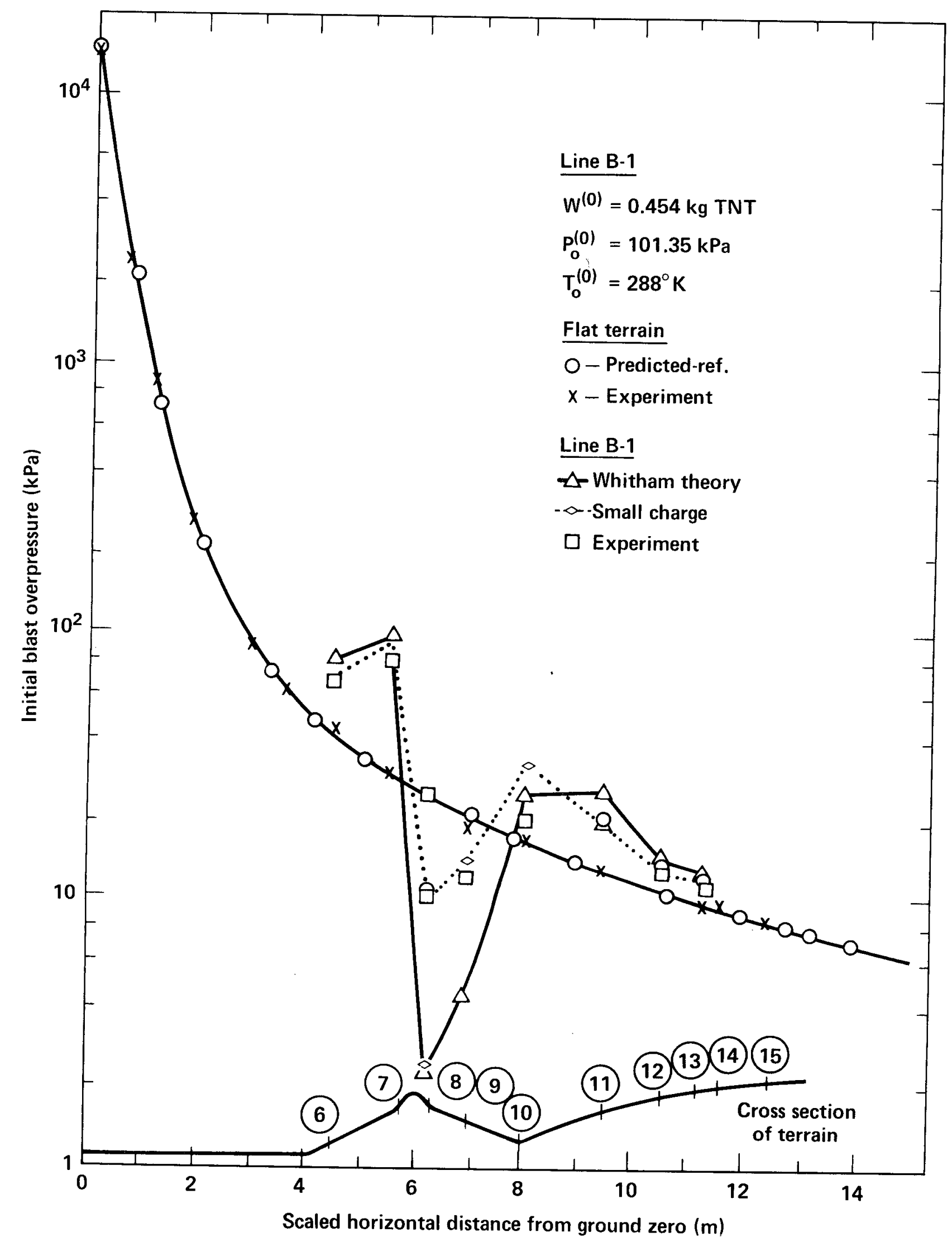

Figure 3. Scaled blast pressure as a function of ground range (from K25). 
Although the above examples deal mainly with large overpressures (greater than $10 \mathrm{psi}$ ) they indicate the effects of slopes on blast-wave overpressures. It appears that blast propagation along inclined slopes may result in changes in overpressure by a factor of less than 3 (certainly less than 10 or 100). We may thus bracket the effect of shielding by terrain with reasonable confidence.

While numerous test results are available on the presure-time history for blast waves in the presence of barriers or structures, there does not appear to be any meaningful correlation of test results. Nor is it clear that any theoretical modeling or prediction has produced directly useful information. At this juncture, then, only some qualitative statements can be made, based mainly on data reported by Coulter [C32]. For example, the front-wall loading was less when the model was shielded than when unshielded; the rear-wall loading was increased by reflections from the back row of shields; the roof of the model did not experience very different loading from one configuration to the next; and the existence of openings (such as windows) on the model caused only minor changes in the exterior load.

No efficient methodology apparently exists for describing blast-wave propagation through specified urban areas.

Thermal Radiation Propagation Through the Atmosphere

Propagation of thermal radiation through the atmosphere was studied extensively in the 1960s. Of main interest was the calculation of the transmissivity of the atmosphere for fireball thermal radiation by Gibbons [G08]. Gibbons also calculated that through heavy clouds the transmissivity of thermal intensity may decrease to as little as one-tenth of that for a clear atmosphere. We believe that calculation of transmissivity is reasonably we11 understood given the atmospheric conditions at the time of attack at a given locale. Of course, this is precisely the information that cannot be predicted beforehand. This uncertainty is further compounded for a multiple-burst situation, and a parametric or a probabilistic approach may be appropriate for estimating the thermal-radiation loading on structures.

Shadowing of thermal radiation by terrain, vegetation, or structures is another problem that $c$ an be solved given sufficient information regarding burst point, target, and intervening objects. The difficulty is in 
calculating a reasonable incident flux history for a large number of targets without being overwhelmed by a huge volume of data.

\section{Conclusions}

Information is lacking in the following areas:

- Multiple-burst effects on thermal radiation transmission and blast-wave propagation.

- Effects of humidity or dust on blast-wave propagation.

- Shadowing and shielding effects of structures on thermal radiation and blast loading in urban areas.

- Methodology for thermal radiation propagation through incompletely specified atmospheres. 
IGNITION

Ignition caused by thermal radiation is one of the more heavily researched parts of the blast and f.-e problem. Ignition criteria for materials exposed to thermal radiation were studied mainly from the mid-1950s to the mid-1960s. The ignition data obtained from the atmospheric nuclear tests were generally qualitative rather than quantitative. Quantitative laboratory data have been obtained using carbon arc and other sources to produce either a square-wave pulse or one intended to represent the essential features of the thermal radiation pulse from a nuclear weapon. The sample orientation has nearly always been vertical and normal to the flux. The most frequently studied materials have been cellulosic, especially samples from a specially prepared batch of alpha cellulose papers. The surfaces have generally been at least nominally clean and black.

In a review of urban fire vulnerability [R09], the parameters affecting free-field ignition of materials were given in approximate order of importance as: fuel thickness or weight per unit area, optical absorptance, weapon yield, burst altitude, relative humidity or recent precipitation, local air currents, chemical composition, extraneous contents (e.g., water and minerals), fuel geometry (e.g., plane or complex) for long pulses only, natural vs manufactured fuels, spectral distribution of thermal radiation, and, for some multiple-burst situations, the time between bursts.

The most extensive compilation of radiant ignition criteria is apparently that given by Glasstone [G12]. The critical radiant fluence is given for three different low-altitude yields. Data are given for clothing and drapery fabrics, tent and other fabrics, household and outdoor tinder materials, and a few construction and other materials. Most of the data were estimated to have a precision of $\pm 50 \%$ for field conditions, and $\pm 25 \%$ under laboratory conditions .

The earlier laboratory data were for square-wave pulses [B105]. The thermal pulse shape of low-altitude bursts was simulated and compared with the earlier laboratory results [M07, M10]. The weapon pulse shape required less energy to ignite alpha cellulose for short exposures and more energy than a square-wave pulse for long exposures. Therefore, two parameters (typically the peak irradiance and time to last maximum) are required to characterize the thermal pulse. 
High-altitude, large-yield weapons produce very intense but very short-length pulses which are difficult to simulate in the laboratory. The available data, however, support the scaling relationships found for longer exposures $[\mathrm{MLO}]$.

Other difficulties with laboratory measurements have been the small area of uniform exposure (e.g., 3/8-3/4" diam), and the almost universal use of vertical samples. It has been suggested that sample' size is important in the regime where convection losses are the decisive factor for ignition [S59]. Buoyancy effects resulted in higher flux and exposure requirements for vertical versus horizontal samples of PMMA Lucite and red oak [K17].

Another factor in determining the amount of energy absorbed is the optical absorptance. The dramatic effect resulting from different target colors has been observed in nuclear explosions and laboratory tests. Since the surface properties change during exposure, however, very little quantitative data are available. The usual assumption is that, at least during a long exposure, a cellulosic material will soon char and therefore have an absorptance near unity. Although no data exist, the spectral distribution of thermal radiation is believed to show up only in the spectral dependence of the target absorptance, if any. As a result of atmospheric absorption and scattering, the incident thermal flux is similar in spectral composition to sunlight.

The ignition process in cellulosic materials has been reviewed in several places by Martin [R09, M15] and more recently by Kanury [K03] and by Steward [s83]. The observed macroscopic parameters can generally be explained using relatively simple heat conduction models, but our understanding of the detailed chemistry and fluid mechanics still leaves many questions.

Martin summarized the behavior of cellulosic materials as indicated in Figure 4. No such detailed correlation has been found for non-cellulosic fuels. The increased use of plastics suggests a need for correlation of data on non-cellulosic fuels in a form useful for predicting primary ignitions.

Data from atmospheric nuclear tests are limited, but they do represent field conditions, although not a wide range of conditions and yields of interest. A small amount of laboratory work has been done to investigate the effects of humidity and mineral content on the ignition of alpha cellulose [M08, B79]. The effects of wind have barely been considered in the ignition problem. The general belief is that wind is not important for short, intense 


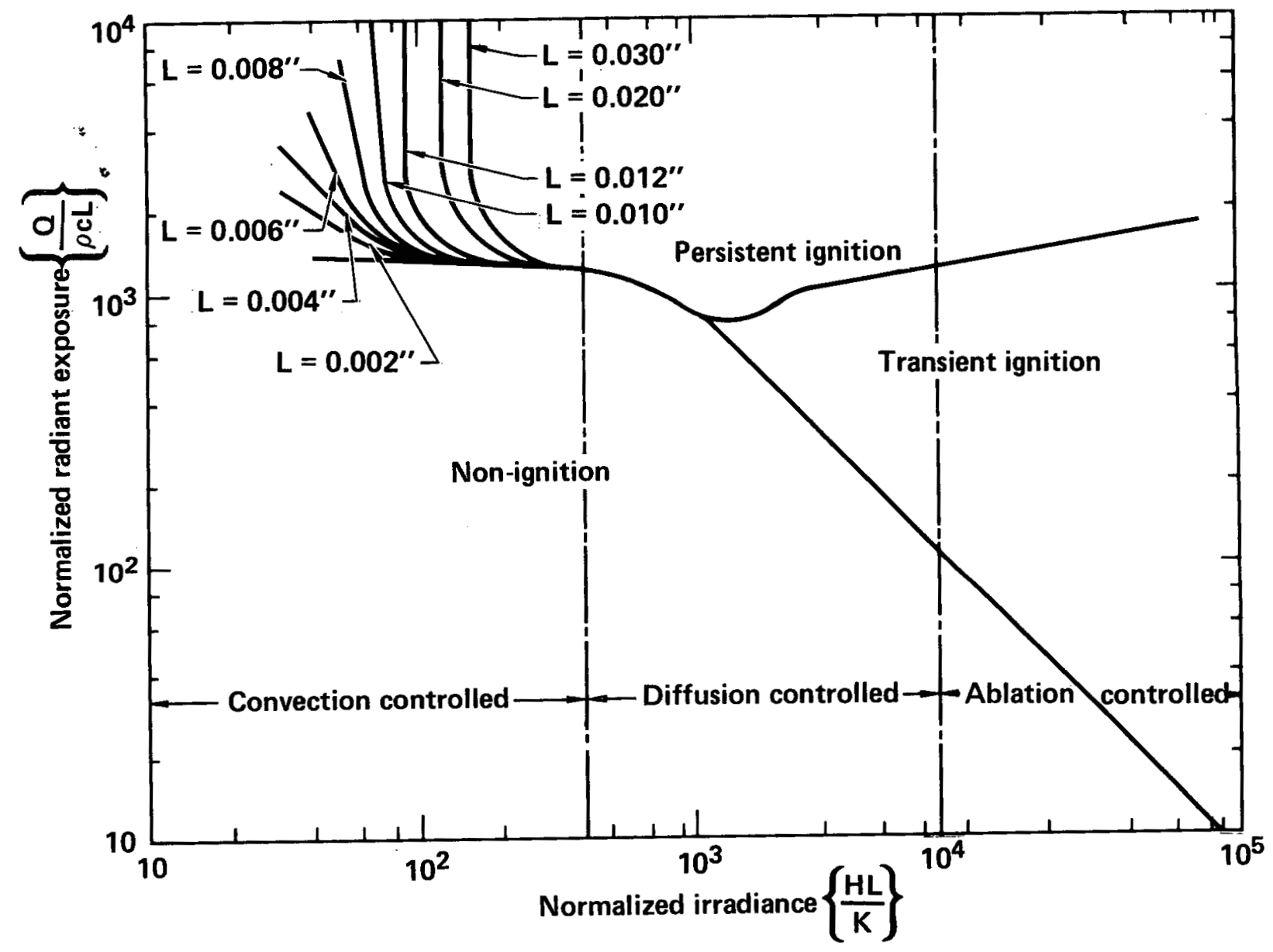

Figure 4. Ignition behavior of cellulose, showing areas controlled by convective cooling, and ablation of the exposed surface (from M16). 
pulses, and that it becomes a factor only for marginal cases where losses are the decisive factor [R09]. [The marginal region determines, however, the reach of primary ignitions and represents a large area because of the large distance from ground zero (GZ).] Very recent precipitation will reduce the fire hazard of exterior fuels.

Ignition of isolated fuels does not represent the actual situation, however. The location and condition of fuels in an urban environment can have a great impact on the fire threat. The ignition of a mixture of thick and thin fuels is more realistic but has not received sufficient attention. Alvares and Wiltshire [A20] found 50\% reduction in critical irradiance for cotton cloth when backed by cotton batting, and appreciable reduction in the time to ignition for cotton cloth in combination with newspaper for high irradiances but not for low irradiances. Waterman and Vodvarka found similar results [W03]. It can be inferred that composite specimens may well be more susceptible to ignition by radiation than the isolated components. The reasons seem to include insulating effects and the piloting of thicker fuels by thinner ones.

As the problem of large-scale urban fires was studied during the $1950 \mathrm{~s}$ and 1960s, the view soon became generally accepted that the primary ignition hazard was due to interior fuels. Exterior fuels tend to be hard to ignite persistently with a short pulse of radiation, and even if ignited the probability of fire spread to a structure was estimated to be low, based on normal fire experience. Brown showed [B85] that there was virtually no chance of persistent ignition of thick, sound wood beyond the region of severe blast damage produced by a weapon of less than 100 MT. Also, the ignitability of interior fuels is much less affected by advërse weather. Consequently, interior ignition by thermal radiation has received the most attention. The scenario is the ignition of thin fuels, fire spread to thicker fuels, and total room involvement, leading eventually to total building involvement in some cases.

This scenario is basically derived from normal, peacetime fire experience. It is known, however, that geometrical complexity can be a factor. Corners behave differently than flat walls, because of multiple reflections. A more important question has been raised recently by Waterman and Martin regarding occurrence of a phenomenon caused by the very high heating rates of enclosures by the thermal radiation pulse. This phenomenon 
is an abrupt flashover, independent of the contents of the enclosure. This was observed in one atmospheric test. (See also [T30].) If it represents the rule rather than the exception, it would completely change the fire spread scenario.

Calculation of shadowing effects is simply a geometrical problem, given the height of burst, yield, and the location and orientations of buildings, hills, and trees, window sizes, and the location of fuels within the rooms [B37]. The problem, of course, is how to represent an urban area in a probabilistic yet meaningful way. Towards this end, a few cities were surveyed in the $1950 \mathrm{~s}$ and 1960s [B92, S13]. Some work has also been done to measure the effect of windows and screens on transmission of radiant energy. Consideration of shadowing and attenuation led Bracciaventi [B40] to conclude that previous estimates of initial fire starts caused by radiation had been overestimated by a factor of 2 .

Secondary fires are those caused by blast effects rather than by thermal radiation, i.e., the blast brings a fuel and an ignition source into contact. Secondary fire danger has been estimated by analysis of sketchy data from Hiroshima and Nagasaki, as well as other war and natura1 disasters [M43, W70]. It is believed that in some circumstances (e.g., in the low-overpressure region), secondary ignitions can exceed primary ones. A notable gap has been the lack of any secondary fire analysis for residential structures.

There was a very small amount of testing in atmospheric shots of secondary fire ignition, but the results were inconclusive. The general belief is that automatic shut-off of gas and electrical power would greatly reduce the secondary fire hazard, but at the same time complicate rescue and survival operations in the immediate post-attack period.

There does not appear to be any practical way to increase the amount of data for estimating the secondary fire hazard. It has been suggested that fires caused by earthquakes are quite similar, but Wilton et al. [W70] contend otherwise. The expense of large-scale HE tests precludes the accumulation of directly relevant data. Probabilistic analysis combining expected structural response with survey data on location, storage, and use of fuels appears to be needed.

Ignition by convection is generally a mode of fire spread rather than start. It is sufficient to note here that little work has been done to establish convective ignition criteria similar to those for radiative 
ignition. Weatherford and co-workers [W18] have studied the phenomenology of convective ignition. As for the more realistic situation in fire spread of mixed radiative and convective ignition, recourse probably should be made to the flammability data for various materials.

Several computer codes were developed during the late 1960 s to predict primary fire ignitions in urban areas. Calculated ignition probabilities were generally based on incident fluence into rooms and the nature of the contents or building use. The urban areas were described with various amounts of detail. The main features of four codes were discussed, and their good and bad points were compared by R. K. Miller et al. [M63].

\section{Conclusions:}

Information is lacking in the following areas:

- Ignition criteria for newer materials, such as plastics.

- Effects of field conditions (e.g., dirt, weathering, condensed water) on radiative ignition criteria.

- Convective ignition criteria for various materials.

- Effects of sample orientation and wind on radiative ignition.

- Effects of geometrically complex arrangements (e.g., corners), mixed thick and thin fuels, and composite materials on ignition criteria.

- Enclosure effects (abrupt flashover).

- Methodology for representing specific urban areas in an efficient yet realistic way.

- Probability of secondary fire ignition for residential structures. 
In addressing the overall blast and fire effects of nuclear weapons on urban areas it is necessary to understand and predict:

- The dynamic response or collapse of structures.

- The debris production, composition, and distribution from damaged structures.

Here we briefly review the existing methodologies for estimating the dynamic response and debris production.

\section{Background}

As a result of a nuclear explosion, a structure may be damaged primarily by three means: fire, blast-induced ground motion, and air blast.

In the first case, the structure may catch fire as a result of the thermal radiation pulse. However, this fire does not act long enough prior to the blast wave arrival to alter the structural response. The surviving fires, i.e., after passage of the blast wave, may well cause severe damage to the ignited and neighboring structures; thus the blast response of fire-damaged buildings may be of interest for multiple-burst attack scenarios. The literature search did not turn up any information on the dynamic response of buildings previously damaged by fire or blast.

The detonation of a nuclear weapon, particularly a surface-burst weapon, can cause large ground motions. The destructiveness of these ground motions, however, are very localized in nature (as compared to the range of the air blast) and therefore only need to be accounted for in structures relatively close to $\mathrm{GZ}$.

Figure 5 shows vertical acceleration as a function of ground range for a surface explosion. This graph demonstrates the rapid attenuation of ground motion with distance. For a $1 \mathrm{kt}$ explosion, the vertical acceleration at a distance of $150 \mathrm{~m}(500 \mathrm{ft}$ ) is approximately $10 \mathrm{~g}$ with a rapid decline to $1 \mathrm{~g}$ at about $350 \mathrm{~m}(1150 \mathrm{ft})$. The ground motions may need to be accounted for in structures located close to GZ. Keyworker shelters, for example, are of ten proposed for underground placement to escape the devastating effects of air blast, and the ground motion may be a controlling factor for design or analysis. Although the ground movements have been measured in various test 


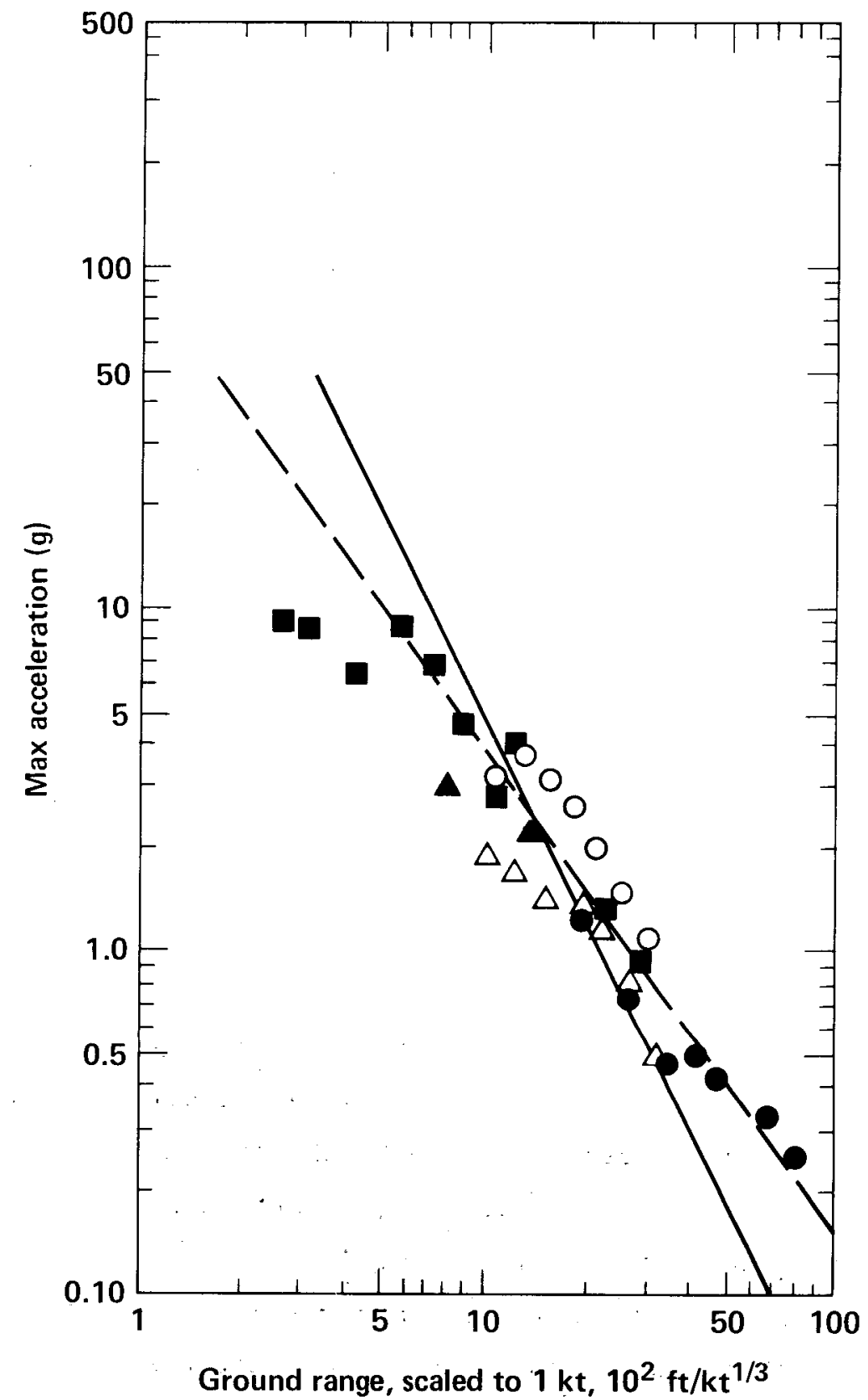

Figure 5. Maximum vertical acceleration vs ground range (corrected to be representative of a surface explosion (from M41). 
situations, ground motions have not been accounted for in any of the structural analysis methods we found in our 1 iterature review; Ref. S26 gives a summary of many tests and some potential problems have been identified by Mason and Walter [M41], especially for saturated soils.

For the majority of structures, air blast loading would be the primary cause of damage and debris production. The blast loading on a structure consists of a "diffraction loading," which is determined mainly by the peak overpressure in the blast wave, and a "drag loading" in which the dynamic pressure is the significant property.* A11 structures are subjected simultaneously to both types of loading, although certain structures may be more sensitive to one type. (A truss bridge, for example, would be subjected primarily to a drag loading.) The actual pressure-time history at each point on the outside surface of a structure is very difficult to predict because of the complexities of the interaction of the blast wave and the structure. Simplified methods of predicting an average external loading on a structure give a reasonably accurate estimation of external pressure for use in dynamic analysis $[\mathrm{G12}, \mathrm{B} 50, \mathrm{~A} 34]$.

Civil defense planners are interested in the modeling of the dynamic response of structures from initial loading through the ranges of elastic and inelastic response and up to failure or collapse for a number of reasons:

- To determine occupant survivability in existing, unhardened structures;

- To determine what, if any, utility the structures would have after an attack;

- To evaluate the feasibility of various hardening schemes;

- To determine the extent, composition, and distribution of debris from the failed or collapsed structure. (The evaluation of debris is important for planning rescue and post-attack recovery operations and to determine the fuel bed for fires.)

The ideal tool for a civil defense planner would be a computer code which, given an attack scenario, could accurately determine the loading on a given structure, the dynamic response with accounting for failure of certain

*Glasstone [G12] gives a good account of the basic phenomena of blast-wave propagation and loading of structures. 
elements, the debris content and distribution resulting from the failure of structural components, and the survivability of personnel in the structure. Such a code would prove valuable in determining the best possible shelters and also in making overall damage estimates.

Unfortunately a model does not exist, on any practical level, for performing all these analyses. There have been significant advances, however, in understanding the basic behavior of structures up to the point of collapse and estimating the dynamic response of structures and debris production. Some important developments are discussed below.

\section{Predicting Dynamic Response of Structures}

The numerous computer programs developed for the elastic analysis of structural systems (both matrix analysis and finite element analysis) are of little use in the dynamic analysis of structural systems up to failure or collapse. The large deflections and markedly nonlinear behavior of structural systems near failure or collapse precludes any simple linear characterization of the structural system. With the exception of a method employed by Lin and Associates [A03] in the early 1960s, the problem of predicting the dynamic response of structural systems has focused on studying, through experimentation and analytical modeling, the dynamic response of individual elements. The information gained from the individual element studies has then been used to model the dynamic response of entire structures. Attempts to model the dynamic response of entire structural systems accurately has probably followed this path because of:

- The feasibility of testing and the availability of test data for blast response of individual structural elements; and

- The overwhelming complexities of the dynamic response of entire structural systems, complicated by the lack of quantitative data. (pressure measurements, deflections, etc.) of entire structures subjected to blast.

\section{Individual Elements}

The most widely accepted method for the dynamic analysis of structural elements appears to be the single-degree-of-freedom (SDOF) method whereby an 
existing structural element, a wall or floor for example, is idealized as a SDOF system. The transformation of the actual element to a SDOF system is dependent on translation factors based on conservation of energy. It is also necessary to obtain a resistance function which is characteristic of the material of the element (reinforced concrete, masonry, etc.) and the type of element (beam, simply-supported plate, fixed plate, etc.). Once the transformation to a SDOF system is made, the equation of motion for the SDOF system can be integrated numerically to determine the deflection of the wall as a function of time.

This process is shown schematically in Figure 6 . The accuracy of the SDOF method is obviously dependent on how accurately the resistance function represents the actual resistance supplied by the member. The resistance functions can be quite complicated, representing many different resistance mechanisms. When resistance functions are developed by analytical methods, confirmation by testing is essential. Figure 7 shows a resistance function developed for a reinforced concrete slab. A number of shock tube tests have provided essential test data on the dynamic response and collapse of individual elements [G01, W69, L51].

The numerical integration of the SDOF equation of motion yields the displacement of the structural element as a function of time and thus predicts the dynamic response of the element. In order to estimate incipient collapse overpressure it is also necessary to establish a failure criteria for the individual elements. This is often based on a maximum center deflection.

Wiehle et al. [W39, W44] have successfully developed and applied the SDOF methodology to a number of structural wall types. Comparison of the analytical results with existing test data shows good correlation. Beck et a1., [B12] have applied the SDOF method to structural elements other than walls, i.e., beams of various support configurations, thin and thick slabs, and buried structures. The accuracy of the analytical predictions for the response of the beam and slab models was quite good. Beck estimates that the SDOF model is capable of estimating the incipient collapse overpressure to within $\pm 15 \%$. 
Real system

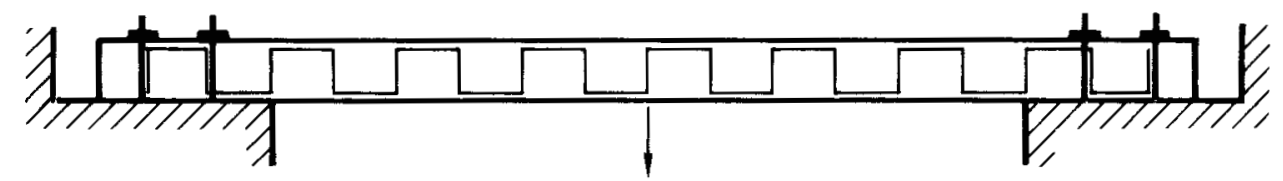

Engineering judgment

Idealized system

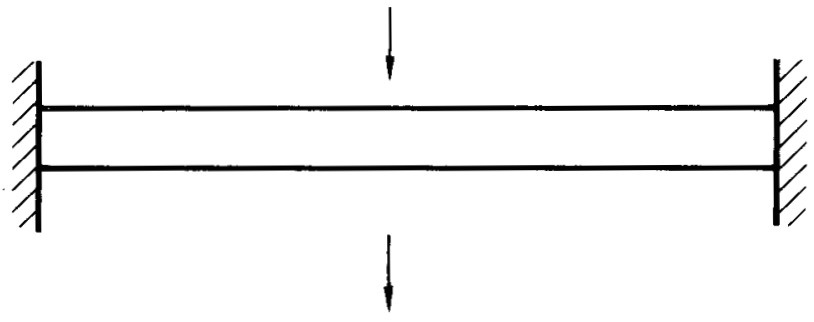

Transformation factors

(load-mass factors)

based on conservation of energy

SDOF model

(physical idealization)

Mathematical model (mathematical idealization)

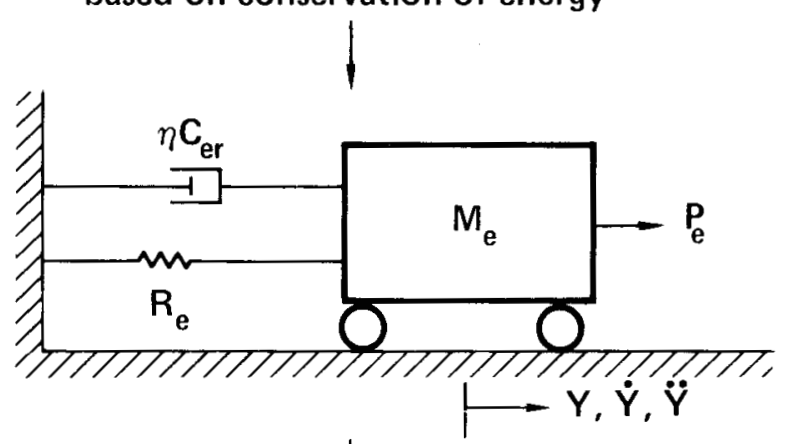

Analytical formulation

Response

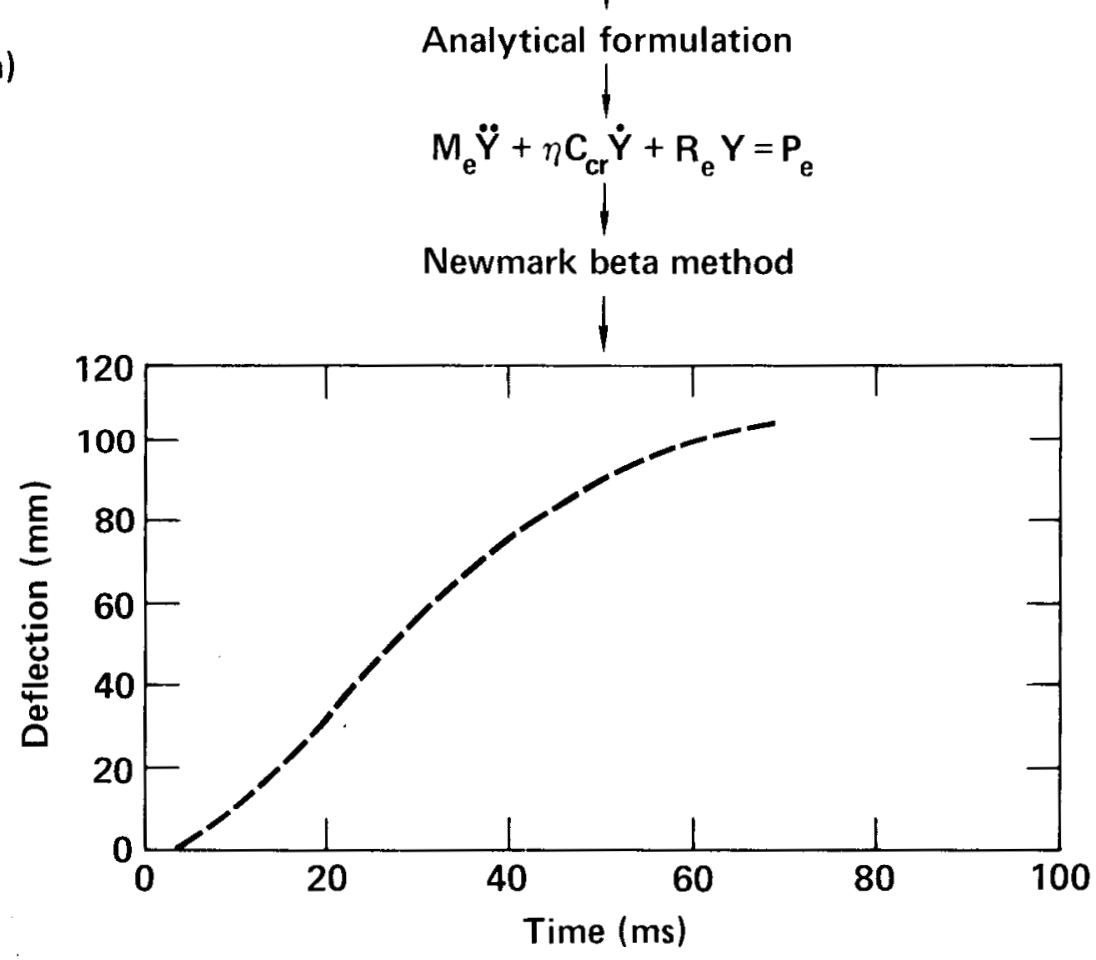

Figure 6. Formulation of SDOF model (from B12). The Newmark beta method is one possible integration method. 


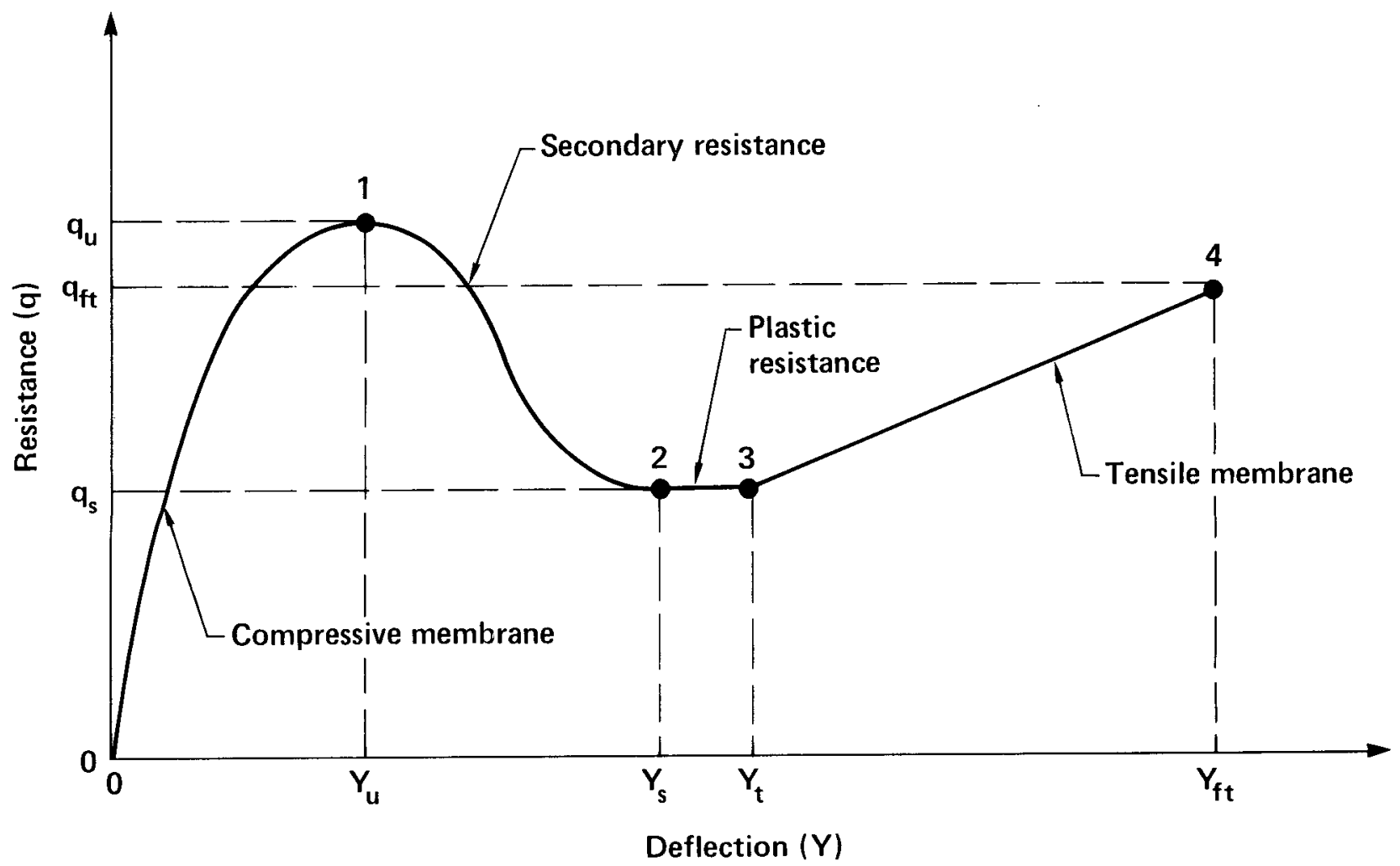

Figure 7. Resistance function of reinforced concrete slab (from B12). 
Structura1 Systems

While the dynamic response and collapse of many individual structural elements is understood and accurately modeled, a computer program does not exist that is capable of predicting the dynamic response of an entire multi-story building from initial yielding to catastrophic collapse. Indeed, this problem is much more difficult because of the complexities of interactions between the blast wave and the structure and interactions between the individual structural elements. An accurate dynamic analysis also requires the prediction of airflow and pressure inside the structure, a very complicated process that has only been attacked by approximate methods even for the simplest geometry [C26, C29, M83]. Some of the attempts to analyze entire structural systems are reviewed below.

The studies performed at SRI between 1968 and 1980, utilizing the SDOF method [W39, W44], laid the groundwork for development of a computer code for the blast response of buildings. The BRACOB (blast response and collapse of buildings) code developed by Rempel [R04, R05] is capable of simultaneously analyzing the response of all exterior walls on one story level of a building. The program treats each individual wall element as a SDOF system. Given a description of the air blast, the floor plan and structural properties, it performs an incremental analysis in time, calculating at each time step the net loading on each wall and the resulting response.

The program alters the floor plan of the structure according to the predicted wall collapse and continues the analysis until either the blast has passed or all walls have collapsed. The BRACOB program utilizes a room filling method given by Rempel [R04] and an exterior air blast loading given by Glasstone [G12]. This code is capable of analyzing only one floor level of a structure and, in its present form, is for the analysis of the walls only, not the frame of the structure.

Results predicted by the BRACOB code have been compared to experimental data gathered in both the Dice Throw and Mill Race* events. In the Dice Throw event [W46] the code successfully predicted damage levels for single story

*Rempel, SRI report in preparation. 
structures at various distances from GZ. The code also successfully predicted the outward collapse of some of the structural walls.

In the mid 1960s, T. Y. Lin and Associates developed a computer program to analyze the dynamic response of high-rise buildings to nuclear blast [A03]. This frame analysis program takes into account the plastic resistance of the structural members. The analysis of a structure using this program requires many assumptions: e.g., it assumes that all walls have failed and that the loading on the exposed frame is caused solely by drag. The program does not tell if the structure has collapsed. It calculates how much ductility the structural members have used (i.e., $\mu=\theta_{\mathrm{p}} / \theta_{\mathrm{e}}$; where $\mu=$ ductility, $\theta_{p}=$ plastic rotation, $\theta_{e}=$ elastic rotation at yield). The structural collapse is assumed to occur when a given ductility level is reached. The assumptions employed in the program appear to be somewhat crude for the blast analysis of a structure. However, this level of simplicity was probably necessary in the early 1960s when data on collapse of structural elements was sparse. As far as we know, the results from this code have never been compared to experimental data, nor are we aware of any existing data appropriate for such a comparison.

Another computer program was developed by Longinow et a1. [L46, L50]. The objective of this code is not to perform a structural analysis per se but to develop a deterministic, computerized model for predicting the survivability of people located in conventional buildings subjected to the direct effects of nuclear weapons. This code is apparently unique in trying to calculate what is of ultimate importance: the number of survivors of nuclear attack. As part of calculating the people survivability, the components of a structure (walls and floors), are analyzed using the SDOF method to estimate incipient collapse overpressure of structural elements. As with the BRACOB code the program calculates in incremental time steps the net loading on a structural element. It compares the net loading on the element to the incipient collapse overpressure in order to determine whether the element will fail. Although the individual analysis (e.g., structural analysis of walls and debris translation) methods have been compared with existing data there does not appear to have been any comparison between the code and experimental results for an entire structural system. (Results from the Mill Race Event could perhaps be used.) This code also predicts debris distribution. 
Multiple-building Studies

Most of the research in the structural area has concentrated on isolated structural elements or single buildings subjected to a single weapon. At some point the single building information must be related to an actual city complex. It appears that shielding is the most important phenomenon which must be accounted for in estimating the dynamic response or collapse of a structure in a city complex.

Recent tests by Coulter [C32] investigated the extent to which adjacent structures altered the blast loading on a particular structure. The HE tests were for various complex configurations with pressure-time histories measured on the "model" structure. Figure 8 shows one of the test configurations. Coulter's conclusions include:

- The front wall model loading was less when shielded in the complexes than when unshielded;

- The rear wall of the model was loaded additionally with reflections from the back row of shields;

- Whether the model had openings caused only minor changes in the exterior loading.

As a result of the first 2 items, there is a decrease in the net translational load on the shielded structure. The presence of the adjacent structure complex reduced the maximum front face overpressure from $60 \mathrm{kPa}$ ( $8.7 \mathrm{psi}$ ) in the unshielded case, to $40 \mathrm{kPa}(5.8 \mathrm{psi})$ in the shielded case. The rear wall, on the other hand, exhibited an increase from about $25 \mathrm{kPa}(3.6 \mathrm{psi})$ to approximately $35 \mathrm{kPa}(5.1 \mathrm{psi})$. Notice that the structures in the complex are of uniform height. If the surrounding structures had been taller than the "model" building, the effects of the shielding would undoubtedly have been larger. This possibility could be important when considering key worker shelters.

\section{Debris Estimation}

Both empirical and analytical methods have been applied to estimate the debris caused by a nuclear weapon. Generally the empirical methods have been applied to the problem of estimating the debris produced in a large area, such as an entire city, subjected to a nuclear blast. The analytical methods, on 


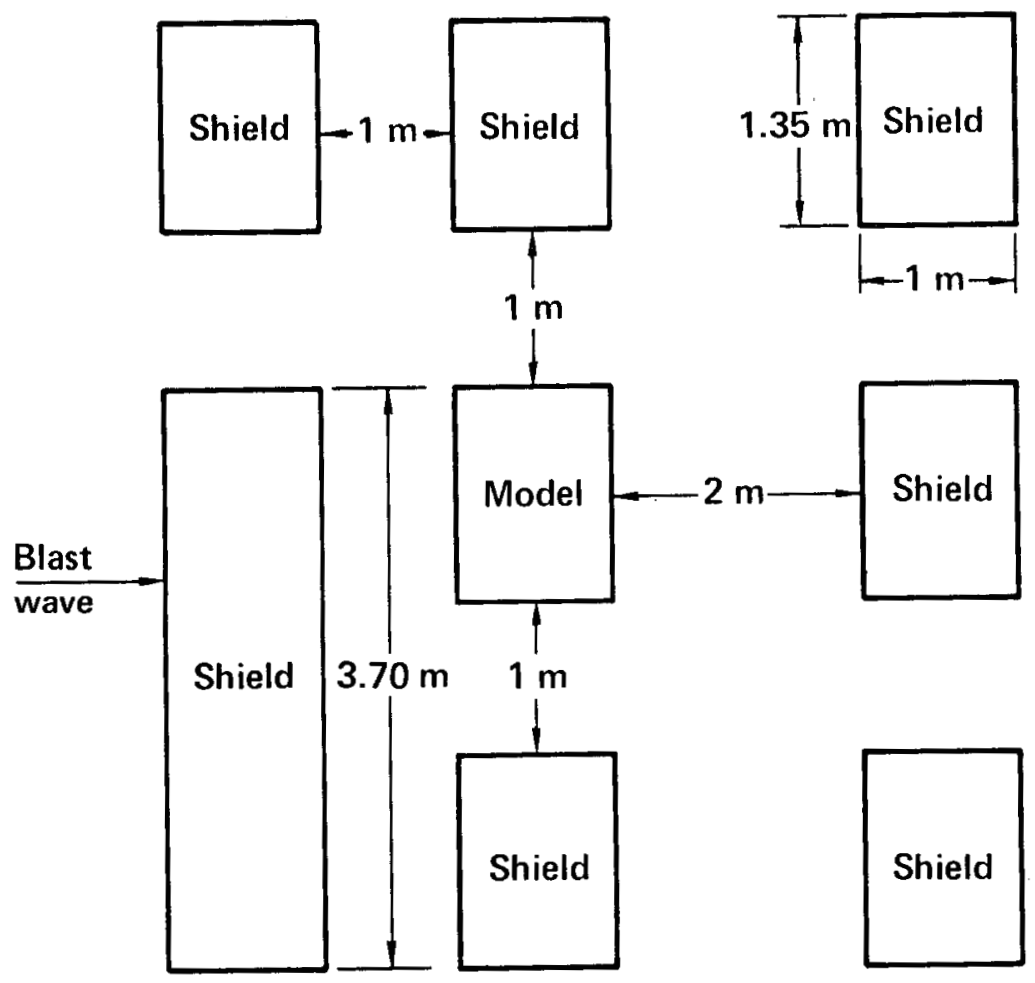

Figure 8. Shielding complex at $0^{\circ}$ angle of incidence to blast wave (from C32). 
the other hand, have been applied to debris production from individual elements and, to a limited extent, to the debris production and distribution from a given building.

Empirical debris estimation procedures have relied on the existing data base from the atomic bomb attacks on Hiroshima and Nagasaki [D02] and from nuclear tests in Nevada and the Pacific. The results of the data reduction have been used to produce debris estimation methods. United Research Services (URS) [E03, E04, R20] has produced debris estimation charts which give the debris production (percentage of building materials) vs incident overpressure for a given yield weapon. Figure 9 shows the results for various types of buildings for a $20 \mathrm{kt}$ weapon. For a larger yield weapon, the increased flow duration would shift the curves to the left. These curves can be used to estimate the debris production in a given area. An assumption about the distribution of the debris is then made. (In the studies reviewed, a uniform distribution was assumed.) The result of the application of this method is a debris depth estimation for various constitutive areas of the city (see Figure 10). The curves produced in this data reduction are useful for gross debris estimation. It appears that as much information as possible has been gleaned from the existing data base with regard to overall debris production.

A number of studies performed by URS and Scientific Services, Inc. (SSI) [L51, W39] were aimed, in part, at gaining test data and analytically modeling debris production and distribution for walls. These studies included a number of shock tunnel tests of various types of walls (e.g. concrete block, brick, reinforced concrete, etc.).

The tests provided information on the behavior of walls near failure and included phenomena such as arching. The test data also provided information on debris production which allowed comparison with simple analytic debris estimation procedures [L51, W39]. Comparison of wall displacements from motion pictures of the tests and predictions of wall displacements made from simple analytical analyses show a surprisingly good correlation for certain wall types. References $\mathrm{L} 51$ and W39 contain photographic data on debris quantity and distribution for various wall types.

Work by Longinow et al. [L46, L50] appears to be the only analytical effort to estimate debris production and final distribution for an entire building. Longinow has included in a computer program a method for predicting the distribution of blast debris which consists of a loading and response 


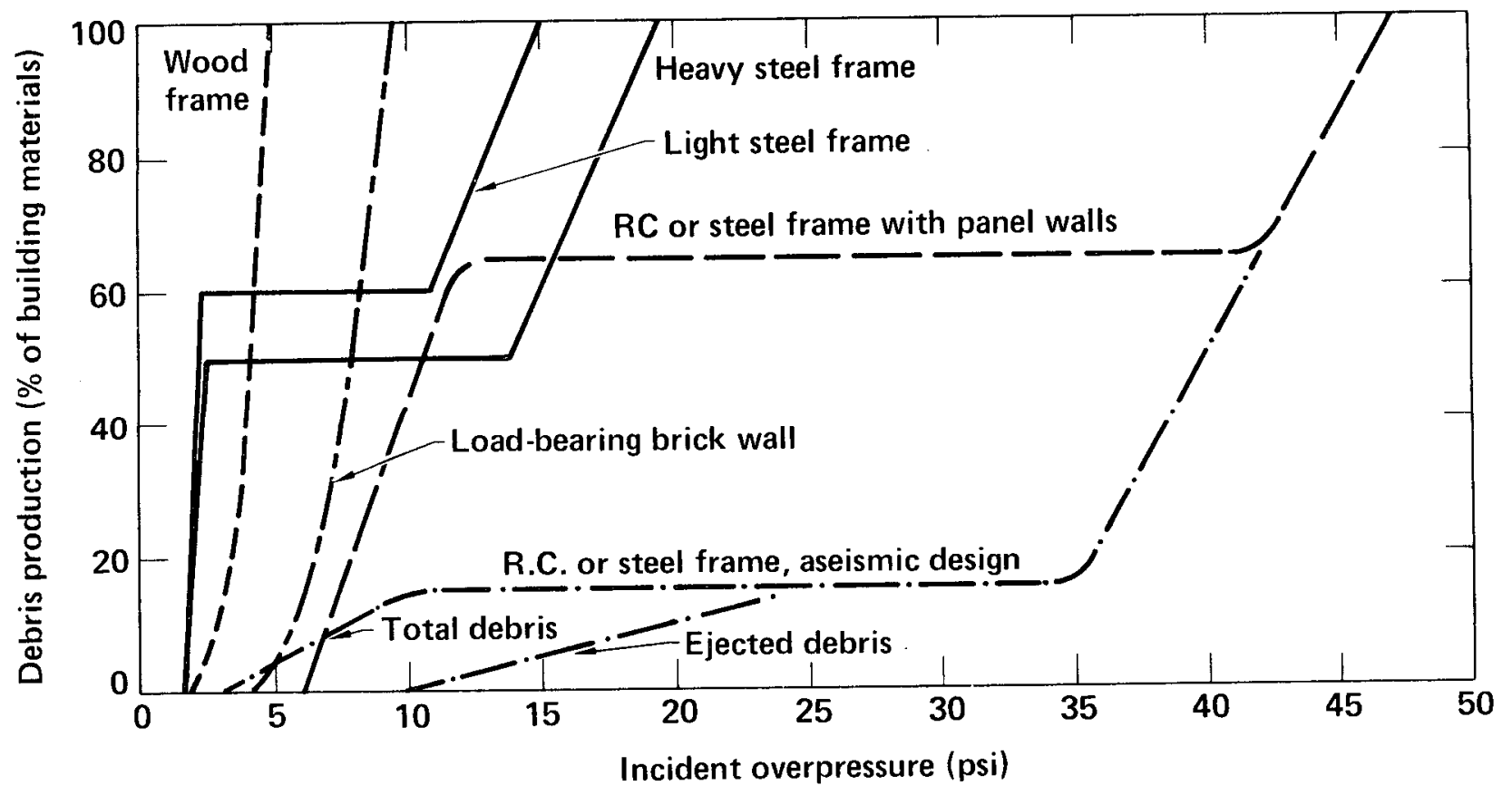

Figure 9. Debris production vs overpressure (from E02). 


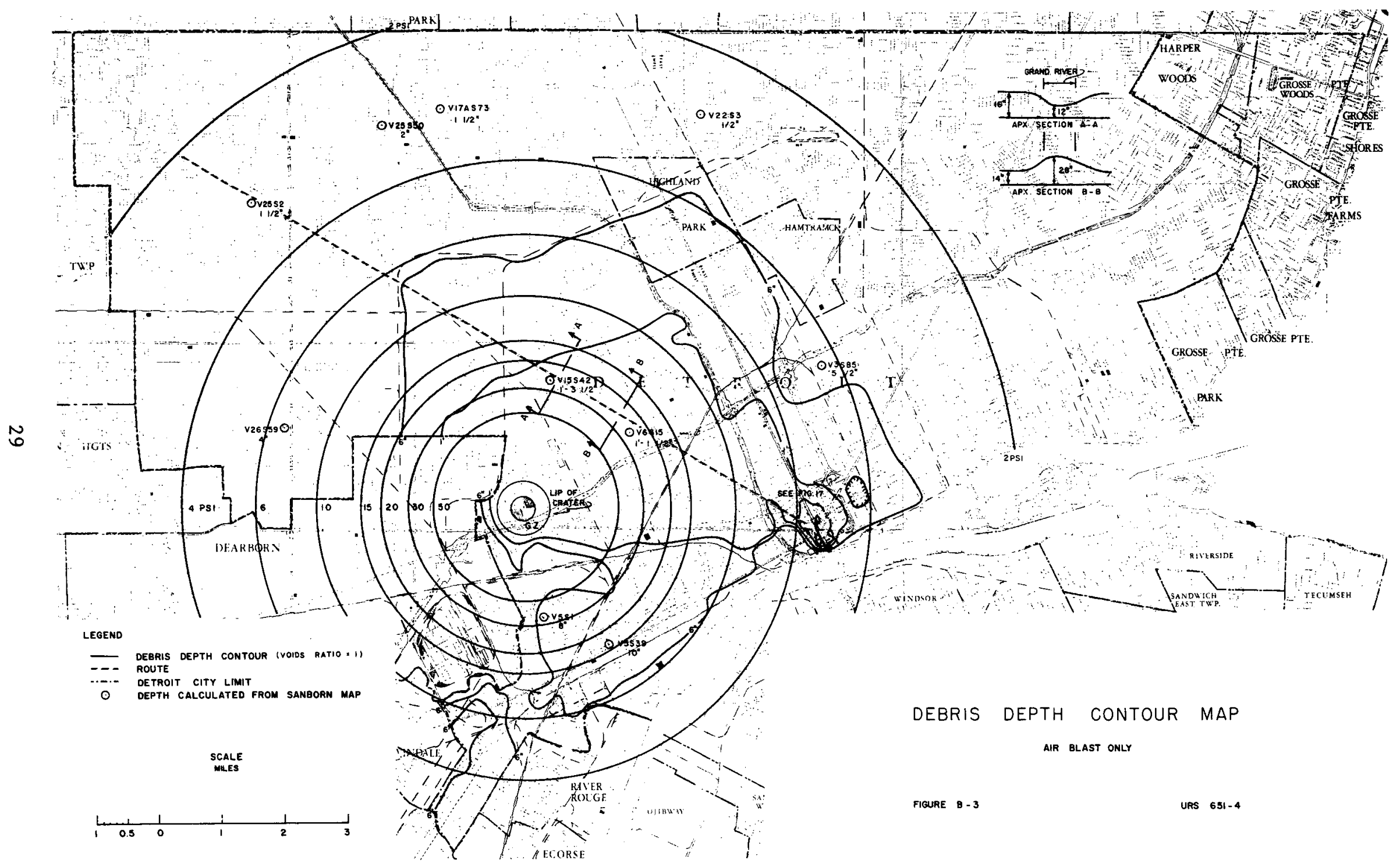

Figure 10. Debris depths for 1-MT attack on Detroit, blast only (from R20). 
analysis for individual structural components and a debris and trajectory analysis.

The program first determines the pressure-time histories acting on the external portions of the building. Then it calculates the average fill pressures and flow velocities in the rooms to determine the time-dependent net loading on the individual components. The transient analysis of each component is then carried out. This analysis determines the incipient collapse overpressure, time of collapse, and average velocities at collapse for exterior walls, interior walls and slabs over basements. The failure pattern of the wall, number of pieces, and sizes are estimated based on full-scale experimental results. The debris transport is then performed using a deterministic, free-flight model. The transport analysis, given the debris size, weight, geometry, and the initial flight characteristics of the debris from the response analysis, predicts the final distribution of debris particles. (See Figure 11.) A detailed account of the trajectory analysis and a sample application are given in [L50].

\section{Observations}

The existing tools for structural analysis are based on the SDOF methodology. These methods essentially predict the response of the individual structural elements (walls) which are assumed to be rigidly supported, i.e., attached to a rigid frame. While this method may be acceptable for relatively simple frame structures, it is not clear that the SDOF method could accurately predict or even be applied to more complicated structures such as tall buildings, for which overturning may be important, or to shear wall buildings which have become more prevalent in recent years. (According to Rempel a possible addition to BRACOB would allow it to handle multi-level buildings by connecting SDOF components at nodes.)

Despite the poor results of some of the finite element method analyses (See Beck [B12]), this method is very powerful and should not be dismissed. Although the existing linear-finite element codes have limited application to the blast problems, some of the newly developed structural analysis codes which account for large deformations and nonlinear stress-strain relationships may be applicable. 


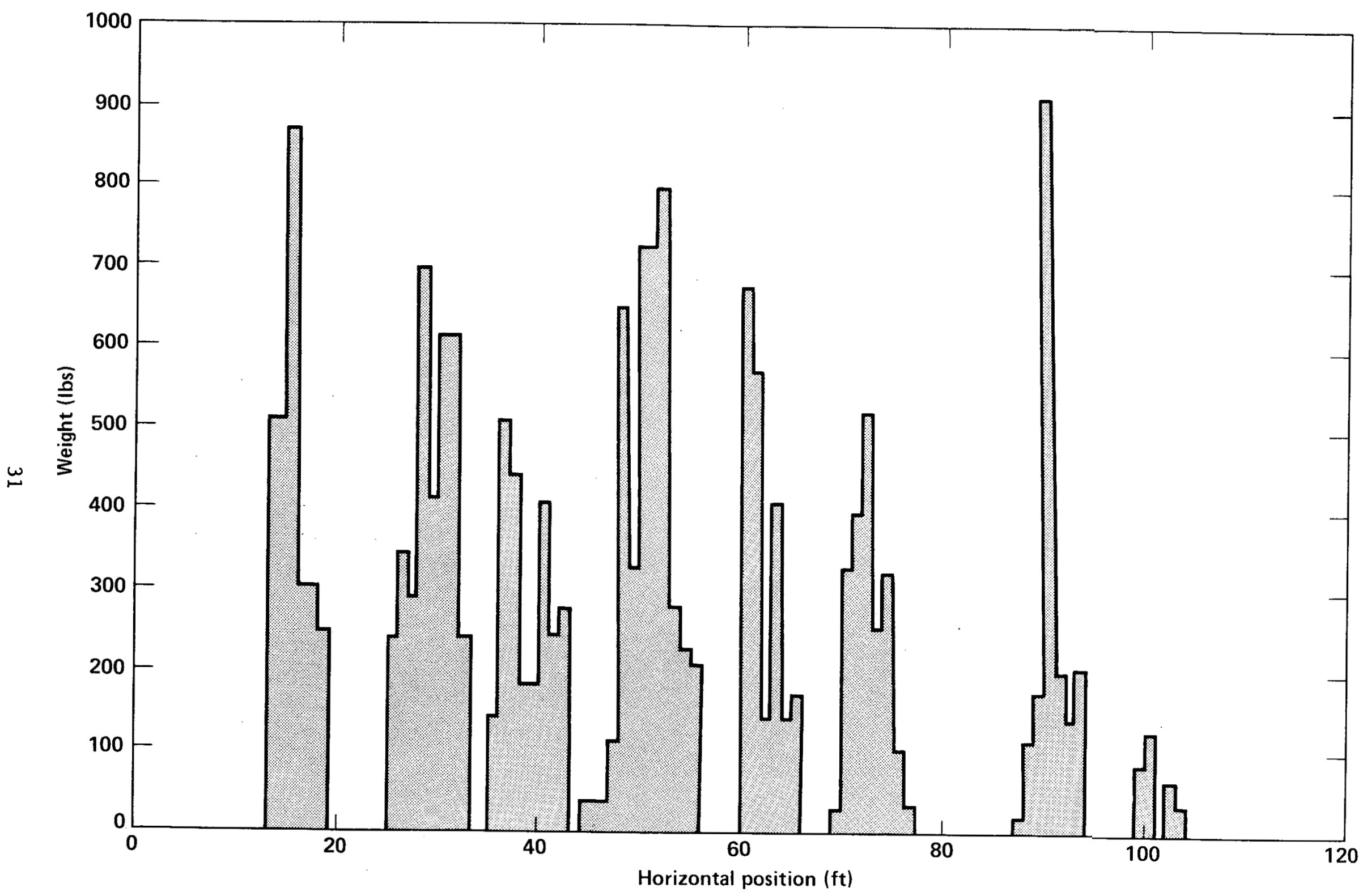

Figure 11. Weight-distance relationship of wall debris (from L46). 
An effort should be made to generate appropriate documentation on existing computer programs. There is currently no manual for the BRACOB code nor for the IITRI codes. Preparation of a manual, a user-oriented source code, and a listing of assumptions and limitations of the programs is necessary for wider use of these codes.

\section{Conclusions}

Information is lacking in the following areas:

- Methods for analysis of dynamic response of entire buildings.

- Experimental data on dynamic response or collapse of entire buildings. (The practicality of testing scale models of large buildings in large $\mathrm{HE}$ shots might be investigated.)

- Empirical data on debris formation and distribution, especially from individual structural elements and single buildings, including typical residential structures.

- Documentation on existing structural response codes. 
FIRE SPREAD

Any development of fire beyond a sustained ignition may be broadly termed "fire spread." The scale can range from an incipient fire on a single fuel element to a firestorm consuming thousands of buildings.

Fire spread on a small scale has long been a subject of interest to the fire community. Fire spread on a larger scale has been of interest almost solely to civil defense and military planners. Forest fires are a significant exception. Forest fires occur frequently on a large scale. Years of study by the Forest Service has resulted in much empirical data and even some predictive capability [C10, R16, A07, A11, S79]. The nuclear weapon effects on forests were discussed in a handbook by Kerr et a1. [K33]. The predictors of forest and wildland fires have two advantages over their urban counterparts. One is the much larger data base of large-scale fires. The other is a better defined and characterized fuel bed.

Another exception to this demarcation based on size has been the problem of blast effects on fires. Blast effects on incipient fires caused by the thermal radiation pulse first became of interest during atmospheric nuclear tests in the early 1950s. This led to laboratory investigations on forest fuels [D01]. Interest revived in the late 1960s, but for blast effects on fires in an urban environment [M29].

During the 1970s several efforts were made to get more data, both in the laboratory [B01, M36, G15] and in an $\mathrm{HE}$ shot [W50]. Important work relevant to civil defense was that of Goodale [G15]. Various types of rooms were modeled in a shock tunnel. Extinguishment of fire was found for all but smoldering fuels for overpressures above 2 psi. Subsequent experiments by others under different conditions have produced conflicting results, however [W49]. Laboratory experiments and theoretical efforts to explain them are still underway.

Blast extinguishment is a complex problem. It depends not only on the type of fuel, but on perturbations to the shock wave. There are questions whether laboratory experiments in shock tubes adequately model the field environment. Test beds, for example, have usually been anchored for observational convenience. Questions remain regarding the importance of the pressure rise after the shock, the duration of the positive pulse, and the effects of the artificial ignition methods. Unfortunately, the field tests 
have been few and generally not particularly illuminating. It has been suggested by Napadensky of IITRI and Alvares of LLNL that it might be useful to study the methods that have been developed empirically for extinguishment of oil field fires. The techniques involve use of a shock wave to blow off the flames and cooling of the fuel to prevent re-establishment.

The possibility of fire enhancement by blast has been mentioned, but does not appear to have been studied. The effects of blast on established fires in structures or debris fields is obviously important in some multiple-burst scenarios, but no relevant work has been found.

The next phase in fire spread, assuming the fire has survived the blast wave, is the spread from thin to thick fuels and possible total room involvement (flashover). This problem is of major importance and thus has received considerable attention by academic and fire protection researchers [T28]. The current knowledge has not, however, been translated into a form useful for the modeling of large-scale urban fire response.

Fire spread from a flashed-over room to other rooms in the structure has also received a fair amount of attention from the larger community of fire researchers [E22]. Here again the information has not been put into suitable form for predictive modeling purposes for civil defense. A common assumption, for example, has been that if even one room flashes over, then the entire building will be destroyed. The SSI model [C40] used a more sophisticated algorithm based on the Gage-Babcock block fire hazard rating system [C18] to estimate the fire susceptibility of structures. Some consideration has been given to the effect on the burn characteristics caused by ignition at different elevations of high-rise structures [T08].

The effects of light-to-moderate blast damage on the burn characteristics of buildings have been investigated in a few experimental burns [VII, WI7]. The amount of data is insufficient for modeling purposes.

Fire spread between buildings can be by radiation, convection, conduction, or by firebrands. Disagreement persists about the relative importance of the mechanisms, although radiation is generally considered dominant between adjacent buildings. Radiative heat transfer is effective for distances of about one building height [R09]. Wind can promote or inhibit this by bending the flames and transporting firebrands. On a larger scale, convective heat transfer and firebrands become increasingly important. 
Renner et al. [R09] listed the fire vulnerability parameters in declining order of importance as: fuel parameters (composition, density, size, continuity, thickness, moisture content, age, ignitability, burning time, heat release, translatability); target parameters [fuel load (on a volume or area basis)], density of buildings (number and size of openings, number and size of enclosures), weather parameters (wind velocity, humidity, air temperature, precipitation, insolation), topographic parameters (slope, aspect, elevation), and other parameters (number and relative location of fires, shape, etc.).

Waterman [W17] provided evidence of enhanced burning and spread between structures as a result of nearby structures. The causes included convective heating, radiant reinforcement, and increased air flow. Some enhancement of fire burn rates was observed also by Wiersma and Martin [W47]. The enhancement is clearly dependent on the separation distance, window areas, relative heights, etc.

The rate of spread in urban areas has been generally observed to increase linearly with wind speed, except for spreading against the wind. Moisture content of the fuel is not a factor for contiguous spread, but it does affect spread by firebrands [R09], because brands are primarily a hazard to roofs and other exterior fuels. Chandler et al. [C10] analyzed available data on urban fire spread rates and compiled those for which there was sufficient information. They gave conditions under which fire would not spread or would die out in the absence of fire fighting.

The lack of data from fire experience has made assessment of the role of firebrands in urban fire spread difficult. In peacetime, firebrands are usually suppressed, while inadequate data is available for war fires. Alger et al. [A14] observed numerous instances of firespread caused by ignition and formation of firebrands from shake roofs. Their interest was in studying the types and effectiveness of self-help firefighting rather than in studying firebrands per se. During the late 1960s, Waterman and others did several studies to fill in the large gaps in knowledge [W07, V12, W08]. They concluded that glowing firebrands over 1 in. in size, such as produced by 1 in. sheathing, were a serious threat, especially to interior fuels exposed by blast damage to windows and roofs, and to weathered shingles. Shingled roofs produce copious amounts of small firebrands, but these do not pose a large threat. Roofs that remain intact longer produce smaller brands and are therefore less of a spread hazard. Previously blast-damaged structures 
produce larger brands, if some roof remains, because of higher rates of burning, and blast damage greatly increases susceptibility to ignition by brands. The transport and ultimate distribution of firebrands, especially in mass fires, is not known.

Firespread across debris fields is difficult to quantify because of the many variables. Fuel type, density, size and distribution, and weather conditions are important and largely unknown parameters. Some experimental work [W50, W51] has been done, but more is certainly needed before this can be considered sufficiently understood.

The modeling of fire spread [C10, P15, T01, T10, M51, A30, A31] in urban areas has ranged from deterministic to stochastic. Some degree of stochasticism is always a factor in modeling the target areas as well. Phung and Willoughby [P15] used fire data to develop stochastic and deterministic models and to identify missing information. They called for more data on long-range rural spotting (spread by firebrands), effects of wind and humidity on spread rates in urban fuel, burn times for rural and urban fuels, and spread probabilities in urban fuels for various weather conditions.

The IITRI model [T01, T10] represented urban areas by somewhat idealized tracts bounded by firebreaks. Spread within tracts was by radiation or brands; spread between tracts was possible only by brands. Miercort [M51] simplified the IITRI code by replacing detailed calculations with fitted curves.

Weisbecker and Lee [W20] compared three fire spread models developed for civil defense purposes by Takata and Salzberg (IITRI), Martin et al. (URS), and Crowley et al. (Systems Sciences, Inc.). They found the representation of urban areas to be a critical part of the problem since it determines the accuracy of the results and the amount of data and effort required to run the code. They also felt that the modeling of the various physical processes needed to be evaluated more carefully before inclusion in the codes.

A strictly stochastic model of fire spread which incorporates a very large amount of fire data is that of Aoki [A30, A31]. By analyzing Japanese fire data he has fit parabolic isoprobability curves for nine pairs of three common building types. This allows calculation of the probability of spread from one type of structure to another when the separation and building heights are known. Aoki's work was built upon a hypothesis of Hamada. So did the work of Horiuchi [H25], who developed algorithms for firespread as a function 
of wind speed and direction. The applicability of these results to American cities is not clear. Whether or not sufficient data exists on American cities to develop similar algorithms is not known.

The next phase towards a mass fire is the merging of fires from individual structures. This changes the ground level winds and increases the burning rate of adjacent structures. A small amount of work on interactive effects of multiple fires has been done in laboratory as well as in full-scale fires [H31, W47, W17]. The small amount of work on coalescence up to 1966 was reviewed by Martin et al. [M20].

How large fires can merge to form mass fires (conflagrations or firestorms) has not been studied in much detail. Considerable work has been done on firestorms, but the emphasis has been on estimating conditions under which they occur [R12, T35, L35] or how established firestorms might affect atmospheric conditions, not on the details of their evolution from a multitude of smaller fires. One exception was the work of Lommasson et al. [L35] in which it was considered how mass fires might be studied by use of scale models. Parker [P06] also considered this problem. It is well-established that complete modeling is impossible; only selected aspects can be incorporated in a scale model. Mass fires were studied experimentally in the Flambeau series [C36, P03, S85]. It is believed by some that firestorm conditions were achieved during part of the largest Flambeau fire. Not all of the data from the Flambeau series has been fully analyzed, and future tests of such magnitude are unlikely.

Morton et a1. [M70, S72] have generally been credited with having successfully modeled the convective plume of a firestorm. Their results do not apply, however, near the ground--the region of most interest to civil defense.

More recent theoretical work has attempted to determine the effects on the atmosphere as well as conditions within an established firestorm [S67]. Carrier et al. [C08] have continued to emphasize the need to explain the vorticity of firestorms that meteorologists have generally considered a key feature.

In contrast with firestorms, mass conflagrations (moving front, large-scale fires) have received very little attention outside of the forest fire community. The general assumption seems to be that, given the conditions typical of firestorms (e.g., high-fuel density, large number of simultaneous 
ignitions, etc.), a mass conflagration can develop if the ambient windspeed is high enough. The distinguishing feature of a mass conflagration is its ability, similar to firestorms, of modifying atmospheric conditions, which in turn affects the fire behavior. In the case of a conflagration this can result in spread rates exceeding those possible for ordinary fires. Despite the potential. for enormous destruction of life and property, mass conflagrations have generally been dismissed as little more than big fires [RO9].

\section{Conclusions}

Information is lacking in the following areas:

- Conditions under which blast extinguishes or promotes incipient fires.

- Conditions under which established structural or debris fires or wildland fires are extinguished or promoted by blast.

- Effects of light-to-moderate or severe blast damage on burn characteristics of structures.

- Synergistic effects of adjacent burning structures on their burn characteristics.

- Convective ignition criteria for a variety of materials.

- Firebrand production, transport, and ignition threat.

- Fire spread rates across various types of debris fields.

- Effects of wind, humidity, and precipitation on fire spread rates across various types of debris fields.

- Conditions for existence of mass fires.

- Conditions within or near a mass fire, especially a conflagration. 
On the basis of the literature survey on blast and fire effects on urban areas following nuclear attack, we conclude that there has been uneven development of our understanding of the various physical phenomena involved.

Without implying any relative importance by their order, we list below those areas where knowledge appears to be the most deficient.

- Ignition criteria for newer materials, and for all materials under typical use conditions.

- Effects of complex geometry or mixed fuel on ignition criteria.

- Enclosure effects on flashover.

- Conditions under which blast promotes incipient fires.

- Effects of blast damage on the burn characteristics of structures.

- Debris production and distribution from individual building elements and buildings, especially residential.

- Fire spread rates between relatively intact structures for many simultaneous ignitions and through debris fields for various wind and weather conditions.

- Conditions for the existence of mass fires, and conditions within and near them.

- Methodology for thermal radiation propagation through incompletely specified atmospheres.

- Methodology for efficient representation of an urban area in a realistic fashion.

- Methodology for calculating shadowing and shielding effects of a specified urban area.

- Methodology for calculating dynamic response and collapse of entire buildings.

- Multiple-burst effects on thermal radiation and blast-wave loading of targets; effects of blast on established fires; and structural response of structures previously damaged by blast or fire. 


\section{APPENDIX A}

\section{Relative state of knowledge}

The results of the literature survey are summarized in the outline on the following pages. Bear in mind that the rankings are subjective and relative. Almost none of the subjects are understood in the breadth or depth sought in more academic areas. 
I. Attack scenario

1. Target Identification for Various $\mathrm{X}$ Strategic choices

2. Yields,

3. Timing of Bursts for Individual Targets . X

4. Weapon Output Characteristics $\mathrm{X}$

II. Transmission and Shadowing of Thermal Radiation

1. Transmission of Thermal Pulse Through X a Clear Atmosphere

2. Effects of Clouds, Precipitation X (Deterministic)

3. Methodology to Account for Realistic Atmospheric Conditions

4. Shadowing Effects of Terrain,

$\mathrm{X}$ Structures (Deterministic)

5. Methodology to Account for Shadowing Effects in a Realistic Fashion

III. Blast Propagation

1. Blast-Wave Propagation in Free Field,

$\mathrm{X}$ Clear, Still Atmosphere

2. Effects of other Atmospheric Conditions

$\mathbf{X}$

3. Shielding Effects of Specified Terrain

$\mathrm{X}$

4. Shielding Effects of Specified Structures

X

5. Methodology for Shielding Effects in an X 
IV. Radiative Ignition Criteria

1. Identification of Relevant Parameters $\mathrm{X}$ for Sustained and Transient Ignition by Thermal Radiation

2. Understanding of the Effects of Wind, $\mathrm{X}$ Sample Orientation

3. Geometrica11y-Complex, Mixed Fuel, and $\mathrm{X}$ Enclosure Effects

4. Criteria for a Variety of Common Materials with Clean Surfaces

$\mathrm{X}$

5. Same for Materials Which Have Come Into $\mathrm{X}$ Common Use in the Past 20 Years

6. Criteria for a Variety of Common $\mathrm{X}$ Materials with Surfaces Representative of Use Conditions (Dirty, Weathered, Condensation)

V. Blast Effects on Fires

1. Understanding of Conditions for Which

2. Understanding of Conditions for Which Blast Promotes Incipient Fires Structural or Debris Fire

4. Effects of Blast on an Established Wildland Fire

VI. Secondary Fire Ignition

1. Probabilities of Secondary Fire

Ignition as a Function of Blast Loading, Building Type and Use, for Non-Residential Buildings

2. Same, But for Residential Buildings

3. Effects on Burn Characteristics of Structures for Secondary vs Primary Ignition 
VII. Fire Spread Within Relatively-Intact Structures

1. Time from Ignition to Total Room Involvement for Various Types of Buildings (Classical Flashover)

2. Time from Single-Room Involvement to

Tota1-Building Involvement for Various Types of Buildings

3. Burn Characteristics for SingleBuilding Fires, for Various Types of Buildings

4. Effects of Light-to-Moderate Blast Damage (Missing Windows, Roofs) on Burn Characteristics

VIII. Fire Spread Between Relatively Intact Structures

1. Understanding of How Fire Spreads From One Structure to Others, Including Effects of Wind, Humidity, and Precipitation, for Various Combinations of Adjacent Structural Types

2. Synergistic Effects of Adjacent Burning Structures on Their Burn Characteristics

3. Firebrand Production, Transport, and Ignition Threat

IX. Convective Ignition Criteria

1. Identification of Relevant Parameters for Sustained and Transient Ignition by Convective Heating, Including Effects of Wind

2. Data for a Variety of Common Materials

3. Flammability Data for Materials Exposed $\mathrm{X}$ to Mixed Convective and Radiative Sources 
X. Single-Building Response to Blast 1. External Loading History of Isolated X
Structure

2. Internal Room Filling

Single Room, Multiple Rooms,

$\mathrm{X}$

Complex Geometry

$\mathrm{X}$

3. Methodology for Modeling Dynamic

Response and Collapse of Individual

Structural Elements (e.g., Walls,

Floors)

4. Experimental Data for Collapse of

$\mathrm{X}$

Structural Elements

5. Dynamic Response and Collapse Models

$\mathrm{X}$

6. Experimenta1 Data for Collapse of Various

$\mathrm{X}$ Types of Structures

XI. Multiple-Building and Multiple-Burst Response

1. Effects of Shielding on Blast Loading of a

$\mathrm{X}$ Specified Structure in an Urban Area

2. Experimental Data on Blast-Wave Shielding

$\mathrm{X}$

3. Effects of Multiple Bursts on Dynamic

$\mathrm{X}$ Response of Structures

4. Effects of Fire on Structural Response

$\mathrm{X}$

XII. Debris Formation and Transport

1. Understanding of Debris Formation

$\mathrm{X}$ Mechanisms

2. Modeling of Debris Production for

Various Types of Buildings as a

Function of Blast Loading

3. Ultimate Debris Distribution from

$\mathrm{X}$

Various Types of Buildings as a

Function of Blast Loading

4. Experimental Data on Debris Trans-

$\mathrm{X}$

lation and Distribution for Various

Building Types 
XIII. Fire Spread Through Debris and Collapsed Structures

1. Effects of Severe Blast Loading on

$\mathrm{X}$

Subsequent Burn Characteristics of

Various Types of Structures

2. Fire Spread Rates Across Various

$\mathrm{X}$

Types of Debris Fields

3. Effects of Wind, Humidity, and

$\mathrm{X}$

Precipitation on Fire Spread

Rates Across Debris Fields

XIV. Mass Fires

1. Understanding of Conditions Under which

$\mathrm{X}$

Individual Fires Merge, and the Effects of Merging on Burn Characteristics of

Structures

2. Conditions for Existence of Firestorms

$\mathrm{X}$

3. Conditions for Existence of Mass X

4. Physical Conditions Within a Firestorm X

5. Physical Conditions Within and Near

$\mathrm{X}$

XV. Fire Spread Through Wildland Areas

1. Understanding of Fire Spread in Wildland $\mathrm{X}$ Areas

2. Rates of Fire Spread Through Various X Fue ls

3. Effects of Wind, Humidity, and

Precipitation on Rates of Fire Spread

$\mathrm{X}$ 
This bibliography is arranged alphabetically by first author. The order for multiple entries by an author is chronological. Wherever possible an AD or $\mathrm{PB}$ number is given to facilitate ordering from the Defense Technical Information Center (DTIC) in Alexandria, Virginia or the National Technical Information Service (NTIS) in Springfield, Virginia, respectively.

If an " $L$ " follows the document's $A D$ number, its distribution has been limited by the research sponsor even though the document may be unclassified. (Any classification is noted.)

We do not claim that this is a complete bibliography, even for the past 25 years. In many cases, particularly for fire, it is difficult to draw the 1 ine between relevant and interesting. It is hoped that the titles are sufficient to indicate whether obtaining the document is worthwhile. We have not made heroic efforts to obtain obscure documents or journals since we felt it would be more useful to 1 ist documents that are readily available. We probably missed some gems, but we hope that we have avoided raising unrealizable hopes as well.

There are a few reports that have not been entered into the DTIC or NTIS systems. In these cases a corporate number has been given. For reference these organizations are identified below:

ARBL--Army Ballistic Research Laboratory; Aberdeen, MD BRI--Building Research Institute, Japan DNA--Defense Nuclear Agency; Washington, DC NRDL--Naval Radiological Defense Laboratory; formerly of San Francisco, CA ORNL--Oak Ridge National Laboratory; Oak Ridge, TN PSR--Pacific-Sierre Research; Santa Monica, CA SAI--Scientific Applications, Inc.; La Jolla, CA SRI--SRI International; Menlo Park, CA URS--United Research Services; formerly of Burlingame and San Mateo, CA W'T--Atomic Energy Commission report series 
A01. J. S. ADAMS, D. W. Williams, J. Tregellas-Williams, "Air Velocity, Temperature, and Radiant-Heat Measurements Within and Around a Large Free-Burning Fire," 14th Int. Symp. Combustion, 1045 (1972).

A02. R. ADAMS, I. R. Stubbs, AD-651009, Manual of Data Gathering Practice Relative to Reusability of Buildings After a Warfire, May 1966.

A03. R. ADAMS, I. R. Stubbs, AD-651010, Trial Survey and Analys is of Several Buildings Relative to Their Reusability After a Warfire, May 1966.

A04. E. B. AHLERS, AD-342723, Debris Hazards, a Fundamental Study, 1963.

A05. F. A. ALBINI, S. Rand, AD-351048L, Effects of Fires From the Nuclear Thermal Weapon, March 1964.

A06. F. A. ALBINI, AD-470988, Considerations of the Mechanisms of Firespread Through Brush, Apri1 1965 .

A07. F. A. ALBINI, "A Physical Model for Firespread in Brush," 11th Int. Symp. Combustion, 553 (1966).

A08. F. A. ALBINI, G. N. Korovin, E. H. Gorovaya, PB81-191512, Mathematical Analysis of Forest Fire Suppression, June 1978.

A09. F. A. ALBINI, PB81-181943, Spot Fire Distance from Burning Trees - A Predictive Model, July 1979 .

Al0. F. A. ALBINI, C. H. Chase, PB81-205742, Fire Containment Equations for Pocket Calculators, Jan. 1980.

Al1. F. A. ALBINI, PB81-184053, Spot Fire Distance from Isolated Sources Extensions of a Predictive Mode1, March 1981.

A12. F. A. ALBINI, "A Model for the Wind-Blown Flame from a line Fire," Combustion Flame 43, 155 (1981).

A13. S. ALGER, R. Nichols, $A D-730031$, Survey of Fires in Hypobaric and Hyperboric Chambers, July 1971.

A14. R. S. ALGER, F. I. Laughridge, J. R. Nichols, L. L. Wiltshire, N. J. Alvares, $\mathrm{AD}-736605$, The Great Oakland, Los Angeles, and San Diego Fires of Sept. 1970, Nov. 1971 .

A15. S. ALGER, B. Martin, AD-A077914, Blast/Fire Interactions (1979 Asilomar Conference), Sept. 1979.

A16. R. L. ALPERT, "Turbulent Ceiling Jet Induced by Large-Scale Fires," Combust. Sci. Technol. 11, 197 (1975).

A17. R. L. ALPERT, "Pressure Modeling of Fires Controlled by Radiation," 16th Int. Symp. Combustion, 1489 (1976). 
A18. N. J. ALVARES, AD-600768, Measurement of Temperatures of Therma11y Irradiated Surface of Alpha-Cellulose, March 1964.

A19. N. ALVARES, T. Anderson, AD-663086, Ignition Hardening of Cellulosic Materials, Aug. 1967.

A20. N. J. ALVARES, L. L. Wiltshire, AD-835013L, Ignition and Fire Spread in a Thermal Radiation Field, May 1968.

A21. N. J. Alvares, S. B. Martin, "Mechanisms of Ignition of Thermal1y Irradiated Cellulose," 13th Int. Symp. Combustion, 905 (1970).

A22. N. J. ALVARES, P. L. Blackshear, A. M. Kanury, "The Influence of Free Convection on the Ignition of Vertical Cellulosic Panels by Thermal Radiation," Combust. Sci. Tech. 1, 407 (1970).

A23. J. E. AMBROSE, L. A. Eggleston, C. H. Yuil1, AD-416537, The Use of Models for the Investigation of Fire Spread, Aug. 1963.

A24. H. E. ANDERSON, R. C. Rotherme1, "Influence of Moisture and Wind Upon the Characteristics of Free-Burning Fires," 10th Int. Symp. Combustion, 1009 (1964).

A25. H. E. ANDERSON, "A Mass Fire in Coniferous Timber Under Severe Burning Condition," in AD-870088L, Mass Fire Symposium, Canberra, Australia, Feb. 1969.

A26. A. ANG, N. M. Newmark, AD-411261, Computation of Underground Structural Response, June 1963.

A27. K. ANNAMALAI, M. Sibulkin, "Ignition and Flame Spread Tests of Cellular Plastics," J. Fire Flammability 9, 445 (1978).

A28. K. ANNAMALAI, M. Sibulkin, "Flame Spread Over Combustible Surfaces for Laminar Flow Systems, Part I: Excess Fuel and Heat Flux," Combust. Sci. Tech. 19, 167 (1979).

A29. K. ANNAMAlaI, M. Sibulking, "Flame Spread Over Combustible Surfaces for Laminar Flow Systems, Part II: Flame Heights and Fire Spread Rates," Combust. Sci. Tech. 19, 185 (1979).

A30. Y. AOKI, Japanese BRI Paper 非80, Studies on Probabilistic Spread of Fire, Nov. 1978.

A31. Y. AOKI, A Stochastic Model of Fire Spread in an Urban Area, translation by Carnegie-Mellon Univ. Dept. Civil Eng., Pittsburgh, 1981. 
A32. R. ARAVE, N. Wallace, DASA-1732, URS 649-6, Dynamic Pressure from Blast Waves: Methods for Predicting the Effects of Terrain, Feb. 1966.

A33. K. ARNOLD, WT-506, Operation Snapper: Effects of Atomic Explosions on Forest Fuels, 1952.

A34. ASCE, Technical Committee No. 8, Planning and Design of Tall Buildings, Criteria and Loading: Fire and Blast, Aug. 1972.

A35. S. ATALLAH, "Model Studies of a Forest Fire," Pyrodynamics 2, 53 (1965).

A36. R. A. ATLAS, AD-283825, Factors Influencing the Fire Effects from Thermal Radiation Emitted by a Nuclear Detonation, Aug. 1962.

A37. R. U. AYRES, AD-430059, Special Aspects of Environment Resulting from Various Kinds of Nuclear Wars, Part II: The Use of Scenarios for Evaluating Postattack Disutilities, Jan. 1964.

A38. R. U. AYRES, AD-632279, Environmental Effects of Nuclear Weapons, Vol. 1, Dec. 1965.

A39. R. U. AYRES, AD-632280, Environmental Effects of Nuclear Weapons, Vol. 2, Dec. 1965.

A40. R. U. AYRES, AD-632281, Environmental Effects of Nuclear Weapons, Vol. 3, Dec. 1965.

B01. J. BACKovSKY, S. Martin, R. McKee, AD-A104135, Blast Effects on Fires, Dec. 1980.

B02. J. BACKOVSKY, S. Martin, R. McKee, (SRI 非YU-3341) Experimental Extinguishment of Fires by Blast, May 1982.

B03. R. BALDWIN, M. A. North, from AD-822599, Firestorm, Its Size and Importance, Oct. 1967.

B04. R. BALDWIN, P. H. Thomas, AD-909432L, Spread of Fire in Buildings Effect of Source of Ignition, Sept. $19 \overline{68 .}$

B05. R. BALDWIN, P. H. Thomas, AD-909431L, The Spread of Fire in Buildings The Effect of the Type of Construction, Dec. 1968.

B06. R. BALDWIN, "Flame Merging in Multiple Fires," Combustion Flame 12, 318 (1968).

B0 7. L. BANET, P. Grinoch, A. Hirschman, T. I. Monahan, AD-B951586, Operation Tumbler-Snapper: Thermal Radiation Measurements Using Passive Indicators, Feb. 1953. 
B08. L. BANET, J. Bracciaventi, AD-049317L, Critical Thermal Energies of Flameproofed Cotton Fabrics, Oct. 1954.

B09. L. BANET, J. Bracciaventi, AD-048702L, Critical Thermal Energies of Curtain Materials, Nov. 1954.

B 10. E. A. BATHKE, D. C. Sachs, J. R. Rentenik, N. P. Hobbs, AD-526751, Investigation of Multiple-Burst Blast and Thermal Environments, Jan. $1973(\mathrm{SRD})$.

B11. J. E. BECK, AD-A088727, Summary of Dynamic Analyses of Selected NSS Buildings, July 1980 .

B12. J. E. BECK, B. M. Beaver, H. S. Levine, E. Q. Richardson, AD-B058018L, Single-Degree-of-Freedom Evaluation, March 1981.

B13. J. M. BECKER, B. Bresler, "Reinforced Concrete Frames in Fire Environments," ASCE J. Structural Div. 103, 211 (1977).

B14. W. G. BERL, AD-769522, Fire Research Abstracts and Reviews, Vo1. 1, Sept. 1959.

B15. W. G. BERL, AD-769523, Fire Research Abstracts and Reviews, Vol 2, Sept. 1960 .

B16. W. G. BERL, AD-769524, Fire Research Abstracts and Reviews, Vo1. 3, Sept. 1961 .

B17. W. G. BERL, AD-769525, Fire Research Abstracts and Reviews, Vo1. 4, Sept. 1962.

B18. W. G. BERL, AD-769526, Fire Research Abstracts and Reviews, Vo1. 5, Sept. 1963.

B19. W. G. BERL, AD-631714, What Basic Fire Research Can Learn From Forest Fires, Oct. 1963.

B20. W. G. BERI, AD-769527, Fire Research Abstracts and Reviews, Vo1. 6, Sept. 1964.

B21. A. L. BERLAD, "Fire Spread in Solid Fuel Arrays," Combustion F1ame 14, 123 (1970).

B22. A. L. BERLAD, R. C. Rotherme1, W. Frandsen, "The Structure of Some Quasi-Steady Fire-Spread Waves," 13th Int. Symp. Combustion, 927 (1970).

B23. G. C. BINNINGER, AD-A093043, Collateral Damage Probability Models, Jan. 1980. 
B24. R. H. BLACK, R. L. Baker, C. B. Colvin, T. C. Goodale, M. B. Hawkins, A. Willson, AD-381772, Exploratory Development of Active Thermal Countermeasures, Oct. 1966 (C-NSI).

B25. P. L. BLACKSHEAR, K. A. Murty, "Heat and Mass Transfer To, From, and Within Cellulosic Solids Burning in Air," 10th Int. Symp. Combustion, 911 (1964).

B26. P. L. BLACKSHEAR, K. A. Murty, "Some Effects of Size, Orientation, and Fuel Molecular Weight on the Burning of Fuel-Soaked Wicks," 11th Int. Symp. Combustion, 545. (1966).

B27. P. L. BLACKSHEAR, from AD-522599, Some Thoughts on Heat and Mass Transfer in Very Large Fires, Oct. 1967.

B28. P. L. BLACKSHEAR, K. A. Murty, J. Matthews, AD-668531, Some Research Pertaining to the Problem of Predicting the Burning Rate of Cellulosic Fuels, Aug. 1968.

B29. P. BLACKSHEAR, J. Matthews, AD-704713, Fire Research - A Collection of Papers, Nov. 1969.

B30. P. L. BLACKSHEAR, A. M. Kanury, "On the Combusion of Wood, I: A Scale Effect in the Pyrolysis of Solids," Combustion Sci. Tech. 2, 1 (1970).

B31. W. S. BLAZOWSKI, R. B. Cole, R. F. McAlevy, "Linear Pyrolysis of Various Polymers Under Combustion Conditions," 14th Int. Symp. Combustion, 1177 (1972).

B32. J. A. BLOCK, "A Theoretical and Experimental Study of Non-Propagating Free-Burning Fires," 13th Int. Symp. Combustion, 971 (1970).

B33. H. BOND, National Fire Protection Association, Fire and the Air War, 1946.

B34. J. H. BOYES, M. P. Kennedy, C. Wilton, AD-A006683, Development of a Long Duration Flow Facility for Studies of Blast-Fire Interaction, June 1974.

B35. J. BRACCIAVENTI, F. Debo1d, AD-249476L, Critical Radiant Exposures for Persistent Ignition of Cellulosic Target Complex Materials, July 1960.

B36. J. BRACCIAVENTI, AD-726001, Fuel Values and Burning Times of Selected Fuel Arrays, March 1961.

B37. J. BRACCIAVENTI, F. Debold, AD-262551L, Research on the Effects of Thermal Radiation on Clean and Soiled Aircraft Skin, June 1961. 
B38. J. BRACCIAVENTI, R. Heilferty, W. L. Derksen, AD-640595, Radiant Exposures for Ignition of Tinder by Thermal Radiation from Nuclear Weapons, July 1966.

B39. J. BRACCIAVENTI, R. Heilferty, W. Derksen, AD-640595, Radiant Exposures for Ignition of Tinder by Thermal Radiation from Nuclear Weapons, 1966.

B40. J. BRACCIAVENTI, AD-643019, Window and Window Screens as Modifiers of Thermal Radiation Released in Nuclear Detonations, Sept. 1966.

B41. J. BRACCIAVENTI, AD-815206L, Investigation of Fire-Starts Due to Nuclear Detonations, April $196 \overline{6}$.

B42. J. BRACCIAVENTI, S. Feldman, AD-825200, Fue1 Array Survey of Providence, Rhode Is land, Sept. 1967.

B43. J. BRACCIAVENTI, S. Feldman, W. Derksen, from AD-822599, A Report on the Investigation of Fire-Starts Due to Nuclear Detonations, Oct. 1967.

B44. J. BRACCIAVENTI, AD-700694, Fire Start Capabilities of Nuclear Detonations in Urban Areas - A Prediction Model, Sept. 1969.

B45. J. BRACCIAVENTI, AD-726001, Fuel Values and Burning Times of Selected Fuel Arrays, March 1971.

B46. J. BRACCIAVENTI, S. Feldman, R. Newman, AD-841542, Fuel Array Survey of Detroit, Michigan, Sept. 1972.

B47. S. K. BRAUMAN, "Effect of Sample Temperature on Combustion Performance of Polymers," J. Fire Flammability 8,210 (1977).

B48. H. L. BRODE, AD-144275, Close-In H-Bomb Effects, Feb. 1956.

B49. H. L. BRODE, R. E. Meyerott, AD-356169, Thermal Radiation from Atomic Detonations at Times Near Breakaway, Aug. 1956 (SRO).

B50. H. L. BRODE, AD-133039L, Nuclear Weapons Phenomena Pertinent to Protective Design, July 1957.

B51. H. L. BRODE, F. R. Gilmore, AD-341110, Estimates of the Thermal Radiation from Nuclear Weapons Burst at High Altitudes, Sept. 1957 (SRD).

B52. H. L. BRODE, AD-150693, Nuclear Blast Wave Calculations Including Thermal Losses, Dec. $195 \overline{7}$ (C-NSI).

B53. H. L. BRODE, AD-338901, Theoretica1 Description of the Early Phases of the Fireball for a Very High Altitude Megaton Explosion, Sept. 1958 (SFRD). 
B54. H. L. BRODE, AD-214945, Underground Phenomenology. Summary and Conclusions, Second Protective Construction Symposium, March 1959.

B55. H. L. BRODE, AD-339817, Theoretical Description of the Blast and Fireball for a Sea Level Megaton Explosion, Sept. 1959, (SRD).

B56. H. L. BRODE, AD-224312, Numerical Calculations of Blast Waves, Feb. 1960.

B57. H. L. BRODE, AD-224316, Weapons Effects for Protective Design, March 1960 .

B58. H. L. BRODE, AD-320493L, Fireball Rise for a High-Altitude Nuclear Explosion, July 1960 .

B59. H. L. BRODE, AD-339868, Initial Cratering and Ground Shock Action Some Implications for High-Yield Weapon Employment and Superhard Design, June 1961, (SRD).

B60. H. L. BRODE, AD-290532, Southern California in a Thermonuclear War, Nov. 1962.

B61. H. L. BRODE, AD-340007, Semi-Empirical Estimates of Superhard Survivability, April 1963, (SRD).

B62. H. L. BRODE, AD-414345, Thermal Radiation from Nuclear Explosions, Aug. 1963.

B63. H. L. BRODE, AD-352526, Nuclear Explosions in Vacuum - Early Stages, Aug. 1964, (SRD).

B64. H. L. BRODE, AD-612197, Fireball Phenomology, Oct. 1964.

B65. H. L. BRODE, AD-361736, Nuclear Blast Calculations, June 1965, (SRD).

B66. H. L. BRODE, AD-625251, A Survey of the Weapons and Hazards Which May Face the People of the U.S. in Wartime, June 1965.

B67. H. L. BRODE, AD-466117, Blast Waves in Tunnels - A Calculated Example, July 1965.

B68. H. L. BRODE, AD-365388, Theoretical Description of the Fireball, Blast, and Thermal Radiation from a Nuclear Explosion at 60,000 Ft., Aug. 1965 (SRD).

B69. H. L. BRODE, AD-623820, Nuclear Explosions in Cavities, Nov. 1965.

B70. H. L. BRODE, AD-369162L, Theoretical Description of the Blast and Fireball for a Sea Level Kiloton Explosion, Jan. 1966. 
B71. H. L. BRODE, R. W. Hillendah1, R. K. Landshoff, AD-672837, Thermal Radiation Phenomena. Vol. V: Radiation Hydrodynamics of High Temperature Air, Nov. 1967.

B72. H. L. BRODE, AD-673530, More Nuclear Explosions in Cavities, June 1968.

B73. H. L. BRODE, "Review of Nuclear Weapons Effects," Ann. Rev. Nuclear Sci. 18, 153-202 (1968).

B74. H. L. BRODE, AD-874060, Height of Burst Effects at High Overpressures, July 1970 .

B75. H. L. BRODE, J. E. Enstrom, AD-732636, Calculation of Gas Expansion in a Rarefied Atmosphere, March 1971.

B76. H. L. BRODE, H. F. Cooper, G. G. Leigh, AD-746705, Hardness, Mobility, Dispersion, Redundancy and Mission Effectiveness Under Nuclear Attack, May 1972.

B77. H. L. BRODE, AD-A059940, Quick Estimates of Peak Overpressure from Two Simultaneous Blast Waves, Dec. 1977.

B78. H, L. BRODE, PSR Note 348, Large-Scale Urban Fires, Dec. 1980.

B79. A. BROIDO, S. B. Martin, AD-268729, Effect of Potassium Bicarbonate on the Ignition of Cellulose by Thermal Radiation, Oct. 1961.

B80. A. BROIDO, "Some Problems in Fire Research," Pyrodynamics 1 , 27 (1964).

B81. A. A. BROWN, R. K. Arnold, W. L. Fons, F. M. Sauer, WT-309, Thermal and Blast Effects on Idealized Forest Fuels, April 1952.

B82. F. W. BROWN, A. Y. Eliason, AD-260957, Protection of Exposed Parts of Shelters Against Thermal Radiation from Megaton Weapons, July 1961.

B83. F. W. BROWN, AD-277575, Ignition of Fires and Fire Spread by Thermal Radiation, June 1962 .

B84. F. W. BROWN, AD-450941, Glow Ignition of Woods Caused by High Thermal Radiation - Ponderosa Pine, Aug. 1964.

B85. F. W BROWN, AD-475535, Ignition of Thick Wood Specimens by High-Temperature Thermal Radiation, Nov. 1965.

B86. W. M. BROWN, AD-701354, Limiting Damage from Nuclear War, Oct. 1969.

B87. H. D. BRUCE, WT-510, Operation Snapper, Project 8.5: Incendiary Effects of Atomic Bomb Tests on Building Sections at Yucca Flat, Oct. 1952 . 
B88. H. D. BRUCE, UKP-64, Operation Upshot-Knothole Project 8.11A: Incendiary Effects on Building and Interior Kindling Fuels, June 1953.

B89. H. D. BRUCE, $A D-460272 \mathrm{~L}$, Incendiary Effects on Building and Interior Kindling Fuels, Dec. 1953:

B90. H. D. BRUCE, AD-317223L, Critical Ignition Energies of 22 Materials by a 3-Second Pulse of Radiation from a $4200^{\circ}$ Graphite Plate, Jan. 1955.

B91. H. D. BRUCE, V. P. Miniutti, L. E. Downs, AD-221962L, Minimum Short Pulse Radiation Energies to Ignite Miscellaneous Materials, Oct. 1955.

B92. H. D. BRUCE, L. E. Downs, AD-255432, A Method for Estimating Probable Ignitions of Interior Fuels by Atomic Weapon Explosion (Survey of Boston and Detroit), Feb. 1956.

B93. H. D. BRUCE, W. L. Fons, AD-153166, Effect of Moisture Content on the Critical Ignition Energies of Some Combustible Materials, Oct. 1957 (SFRD).

B94. H. D. BRUCE, L. E. Downs, AD-206657L, Ignition of Newspaper by Radiation with Variations in Moisture Content and Pulse Time, Oct. 1958.

B95. H. BRUNSWIG, AD-652618, Practical Experience of Fire Protection Services, English Edition, Part I, June 1966.

B96. H. BRUNSWIG, AD-652619, Practical Experiences of Fire Protection Services, English Edition, Part II, June 1966.

B97. E. J. BRYANT, J. H. Keefer, L. M. Swift, D. C. Sachs, AD 452637 , Effects of Rough and Sloping Terrain on Airblast Phenomena, July 1962.

B98. M. L. BULLEN, P. H. Thomas, "Compartment Fires with Non-Cellulosic Fuels," 17th Int. Symp. Combustion, 1139 (1978).

B99. M. L. BULLEN, "The Burning Rate of Wood Dowels in Smal1-Scale Arrays," J. Fire Flammability 9, 189 (1978).

B100. D. S. BURGESS, A Strasser, J. Gumer, Diffusive Burning of Liquid Fuels in Open Trays," Fire Res. Abst.\& Reviews 3, 177 (1961).

B101. D. BURGESS, J. Gumer, "Comments on 'The Burning Rate of Liquid Fuels from Open Trays by Natural Convection' by D. B. Spalding, "Fire Research Abstracts and Reviews 4, 236 (1962).

B102. R. H. BURROS, "Probability of Failure of Building From Fire," ASCE J. Structural Div. 101, 1947 (1975).

B103. W. B. BUSH, F. E. Fende11, AD-A074065, Analytic Modeling of Turbulent Shear Flow with Chemical Reaction, Apri 1977. 
B104. C. P. BUTLER, R. P. Day, S. B. Martin, W. B. Plum, AD-223183L, The Effect of Pulse Shape on Thermal Radiation Damage to Materials, Dec. 1953.

B105. C. P. BUTLER, S. B. Martin, W. Lai, AD-130650, Thermal Radiation Damage to Cellulosic Materials, Part II: Ignition of Alpha Cellulose by Square-Wave Exposure, Nov. 1956.

B106. C: P. BUTLER, AD-682476, Operation Flambeau: Civil Defense Experiment and Support, June 1968.

B107. C. P. BUTLER, AD-698135, Operation Flambeau - Civil Defense Experiment and Support: Eyewitness Accounts of a Mass Fire, May 1969.

B108. C. P. BUTLER, AD-704144, Camp Parks Mass Fires, Aug. 1969.

B109. C. P. BUTLER, AD-716327, Measurements of the Dynamics of Structural Fires, Aug. 1970.

B110. C. P. BUTLER, S. B. Martin, S. J. Wiersma, "Measurements of the Dynamics of Structural Fires," 14th Int. Symp. Combustion, 1053 (1972).

B111. G. M. BYRAM, R. E. Martin, "Fire Whirlwinds in the Laboratory," Fire Contro1 Notes 23, 13 (1962).

B112. G. M. BYRAM, H. B. Clements, E. R. E11iott, P. M. George, AD-602742, An Experimental Study of Model Fires, June 1964.

B113. G. M. BYRAM, H. B. Clements, M. E. Bishop, R. M. Nelson, AD-633709, Project Fire Mode1: An Experimental Study of Model Fires, June 1966.

B114. G. M. BYRAM, "Scaling Laws for Modeling Mass Fires," Pyrodynamics 2 , 271 (1966).

B115. G. M. BYRAM, R. M. Nelson, "Buoyancy Characteristics of a Fire Heat Source," Fire Technology 10, 68 (1974).

C01. J. M. CALLIGEROS, J. P. Walsh, R. P. Yeghiayan, ARBRL-CR-00421, Structural Modeling and Response of Command, Control and Communication Shelter Systems for Event DICE THROW, March 1980.

C02. G. CARRIER, F. Fende11, P. Feldman, AD-A079368, Forced-Convection Extinction of the Diffusion Flame Supported by a Pyrolyzing Body, Oct. 1979.

C03. G. F. CARRIER, F. E. Fende11, P. S. Feldman, AD-A091000, Nonisobaric Flame Propagation, 1979.

C04. G. F. CARRIER, F. E. Fende11, P. S. Feldman, "Wind-Aided Flame Spread along a Horizontal Fuel Slab," Combust. Sci. Tech. 23, 41 (1980). 
C05. G. CARRIER, F. Fende11, P. Feldman, S. Fink, AD-A101622,

"Forced-Convection Extinction of a Diffusion Flame Sustained by a Charring Body", Combust. Sci. Tech. 28, 271 (1982).

C06. CARRIER, F. E. Fende11, P. Feldman, AD-A107706, Analytic Modeling of Severe Vortical Storms, Oct. 1981.

C07. G. CARRIER, F. Fende11, S. Fink, PB82-183732, Towards Wind- Aided Flame Spread Along a Horizontal Charring Slab: The Steady-Flow Problem, Feb. 1982 .

C08. G. F. CARRIER, F. E. Fende11, P. S. Feldman, TRW 非38163-6001-UT-00, Firestorms, Apri1 1982 .

C09. C. C. CHANDLER, AD-418075, A Study of Mass Fires and Conflagrations, 1963.

C10. C. C. CHANDLER, T. G. Storey, C. D. Tangren, AD -418076 , Prediction of Fire Spread Following Nuclear Explosions, 1963.

C11. C. C. CHANDLER, "Mass Fire Behavior Under Marginal Burning Conditions," in AD-870088L, Mass Fire Symposium, Canberra, Australia, Feb. 1969.

C12. N. P. CHENEY, G. A. V. Bary, "The Propagation of Mass Conflagrations in a Standing Eucalyptus Forest by the Spotting Process," in AD-870088L, Mass Fire Symposium, Canberra, Australia, Feb. 1969.

C13. N. A. CHIGIER, A. Chervinsky, "Aerodynamic Study of Turbulent Free Jets with Swirl," 11th Int. Symp. Combustion, 489 (1966).

C14. J. F. CHRISTIAN, C. C. Chandler, S. B. Martin, F. A. Williams, J. W. Synder, AD-803499L, Minutes of the Fire Phenomenology Workshop, March 1965.

C15. J. E. COCKAYNE, E. V. Lofgren, AD-A048802, Tactical Implications of Air Blast Variations from Nuclear Tests, Nov. 1976.

C16. J. E. COCKAYNE, T. M. Knase1, M. D. McDonne11, AD-A063539, Investigation of Large Scale Optical Flash Sources, April 1978.

C17. J. E. COCKAYNE, R. L. Malinkowski, J. L. Meisner, AD-A098292, Carbon Rod Radiant Source for Blast/Fire Interaction Experiments: Proof of Concept and Design; Aug. 1980.

C18. B. M. COHN, L. E. Almgren, M. Curless, AD-616623, A System for Local Assessment of the Conflagration Potential of Urban Areas, March 1965.

C19. B. M. COHN, AD-643185, The Conflagration Potential in San Jose and Albuquerque, Oct. 1966. 
C20. C. Colvin, T. C. Goodale, M. B. Hawkins, A. Rimas, E. G. Snyder, M. Staackmann, AD-455812, Preliminary Results of Smoke Screen System Development, Jan. 1965.

C21. H. F. COOPER, G. G. Leigh, H. L. Brode, AD-741876, Some Fundamental Aspects of Nuclear Weapons, March 1972.

C22. R. C. CORLETT, "Gas Fires with Pool-Like Boundary Conditions," Combustion Flame 14, 351 (1970).

C23. G. A. COULTER, AD-035258, Two-Dimensional Diffraction of Plane Shock Waves Over a Rectangular Opening, Feb. 1954.

C24. G. A. COULTER, W. T. Mathews, AD-241504, Changes in Drag Caused by Air Blast Shielding, June 1960.

C25. G. A. COULTER, B. P. Bertrand, AD-475669, BRL Shock Tube Facility for the Simulation of Air Blast Effects, Aug. 1965 .

C26. G. A. COULTER, AD-670937, Air Shock Filling of Model Rooms, March 1968.

C27. G. A., COULTER, AD-729775, Air Shock Loading of Exterior Walls of Shelter Models, Aug. 1971 .

C28. G. A. COULTER, AD-751769, Blast Loading in Existing Structures Basement Models, Aug. 1972 .

C29. G. A. COULTER, V. B. Kucher, AD-A017746, Computer Predictions for Blast Wave Induced Flow in a Room She1ter, Oct. 1975.

C30. G. A. COULTER, AD-A056315, Translation and Impingement of Furniture Debris in a Model Apartment House Shelter, May 1978.

C31. G. A. COULTER, AD-A083295, B1ast Loading Predictions for German Structure No. 2 - Dice Throw Event, March 1980.

C32. G. A. COULTER, AD-A090701, Shielding from Blast Effects - 1/8th Scale Model City Complex, July 1980.

C33. G. A. COULTER, AD-B051280L, Blast Wave Loading of a $1 / 15$ th Scale Mode1 House, July 1980.

C34. G. A. COULTER, AD-B063574L, Blast Loading of Wall Panels and Commercial Closures, Feb. 1982 .

C35. C. M. COUNTRYMAN, AD-610711, Mass Fires and Fire Behavior, 1964. 
C36. C. COUNTRYMAN, AD-710979, Project Flambeau Investigation of Mass Fire, Vol. I, 1969 .

C37. G. CoX, R. Chitty, "A Study of the Deterministic Properties of Unbounded Fire Plumes," Combustion Flame 39, 191 (1980).

C38. R. H. CRAVER, M. Drake, J. T. McGahan, J. F. Schneider, E. Swick, AD-C020813, The Feasibility of Population Targeting, June 1979 (SRD).

C39. G. A. CRISTY, AD-A014626, Best She1ter for Critical Industry Workers, Aug. 1975.

C40. J. W. CROWLEY, B. R. Smith, H. J. Avise, N. G. Whitney, AD-673797, FIREFLY: A Computer Mode1 to Assess the Extent of Nuclear Fire Damage in Urbanized Areas, May 1968.

C41. J. W. CROWLEY, R. M. Hogue, H. J. Alvise, E. H. Smith, W. G. Riner, AD-842356, Development of Analytical Relationships for Blast and Fire Vulnerability of Fallout Shelter Occupants, Oct. 1968.

D01. P. R. DAHL, A. G. Guibert, AD-040820, Forest Fuels Blast Studies, March 1954.

D02. R. D. DANIELS, G. R. Johnson, AD-A053482, Statistical Analysis of Japanese Damage Data, Jan. 1977.

D03. L. W. DAVIS, F. J. Wa11, D. L. Summers, AD-623087, Development of "Typical" Urban Areas and Associated Casualty Curves, April 1965.

D04. L. W. DAVIS, W. L. Baker, D. L. Summers, AD-653922, Analys is of Japanese Nuclear Casualty Data, April 1966.

D05. V. W. DAVIS, T. Goodale, K. Kaplan, A. R. Kriebel, H. G. Mason, AD-527669, Nuclear Weapons Blast Phenomena, Vol. IV: Simulation of Nuclear Airblast Phenomena with High Explosives, July 1973 (SFRD).

D06. A. DAYAN, C. L. Tien, "Radiant Heating from a Cylindrical Fire Column," Comb. Sci. Tech. 9, 41 (1974).

D07. J. C. DeHAVEN, AD-606456, A Commentary on Fire Research, Based on the Mass Fire Study Group Conference at UCLA, July 1957.

D08. M. A. DELICHATSIOS, "Fire Growth Rates in Wood Cribs," Combustion Flame 27, 267 (1976).

D09. J. N. DE RIS, "Spread of a Laminar Diffusion Flame," 12th Int. Symp. Combustion, 241 (1968).

D10. J. DE RIS, A. M. Kanury, M. C. Yuen, "Pressure Modeling of Fires," 14th Int. Symp. Combustion, 1033 (1972). 
D11. J. DE RIS, L. Orloff, "The Role of Buoyancy Direction and Radiation in Turbulent Diffusion Flames on Surfaces," 15th Int. Symp. Combustion, 175 (1974).

D12. J. DE RIS, "Fire Radiation -- A Review," 17th Int. Symp. Combustion, 1003,1978 .

D13. L. I. DEVERALL, W. Lai, "A Criterion for Thermal Ignition of Cellulosic Materials," Combustion Flame 13, 8 (1969).

D14. E. DODSON, AD-511949, Civil Defense, January 1967.

D15. P. J. DOLAN, AD-526125 and AD-526126, Capabilities of Nuclear Weapons, Parts I and II, DNA, Washington, D.C., July 1971 (SRD).

D16. H. DORSETT, AD-873029L, 8th Annual OCD Fire Research Contractors Meeting, Apri1 1970.

D17. H. DORSETT, AD-887557L, 9th Annual OCD Fire Research Contractors Meeting, May 1971 .

D18. H. G. DORSETT, AD 902507L, 10th Annual DCPA Fire Research Contractors Meeting, April 1972.

D19. J. DOUGLASS, A. Hoeber, Soviet Strategy for Nuclear War, Hoover Institution Press, Stanford, 1979 .

D20. L. E. DOWNS, H. D. Bruce, AD-271462, Effect of Window Glass in Protecting Materials from Ignition by Thermal Radiation, Nov. 1955.

D21. L. E. DOWNS, H. D. Bruce, AD-141169L, Attenuation by Window Screens of Thermal Radiation from Nuclear Weapons, March 1957.

D22. M. S. DUVVURI, S. P. Muhlenkamp, K. Z. Iqbal, J. R. Welker, "The Pyrolysis of Natural Fuels," J. Fire Flammability 6 , 468 (1975).

D23. M. K. DRAKE, M. P. Fricke, D. E. Groce, D. C. Kaul, C. J. Rindfleisch, AD-A071371, Collateral Damage, Oct. 1978.

E01. S. E. EASTMAN, AD-481846, The Effects of Nuclear Weapons on a Single City: A Pilot Stdy of Houston, Texas, Sept. 1965.

E02. J. E. EDMUNDS, C. K. Wiehle, K. Kaplan, AD-450115, Structural Debris Caused by Nuclear Blast, Oct. 1964.

E03. J. E. EDMUNDS, P. M. Sears, AD-857239, Debris Mode1 Research and Five-City Study Applications, June 1968.

E04. J. E. EDMUNDS, AD-857886, Structura1 Debris and Building Damage Prediction Methods, June 1968. 
E05. J. E. EDMUNDS, AD-698485, Debris Prediction Mode1, June 1969.

E06. L. A. EGGLESTON, H. I. Hoffman, H. M. Smith, C. H. Yuil1, AD-416537, The Use of Models for the Investigation of Fire Spread, August 1963.

E07. L. A. EGGLESTON, J. E. Ambrose, W. W. Bradshaw, C. H. Yui11, AD-609283, The Development of Models for Use in the Investigation of Fire Spread, Nov. 1964.

E08. L. A. EGGLESTON, A. J. Pryor, W. D. Weatherford, C. H. Yuill, $\mathrm{AD}-628783$, The Use of Models for the Investigation of Fire Spread, Feb. 1966.

E09. L. A. EGGLESTON, AD-684941, Fire Defense Systems Analysis, Feb. 1969.

E10. L. EGGLESTON, AD-716006, Fire Defense Systems Analysis: Application of Concepts to the San Jose Metropolitan Area, Oct. 1970.

E11. P. A. ELLIS, D. C. Sachs, C. I. Malme, S. B. Klingman, W. Davis, AD-511266L, Nuclear Weapons Blast Phenomena, Vol. III: Air and Subsurface Explosions, March 1970 (SFRD).

E12. P. A. ELLIS, D. C. Sachs, P. J. Morris, AD-513590L, Nuclear Weapons Blast Phenomena, Vol. II: Blast Wave Interaction, Dec. 1970.

E13. H. W. EMMONS, "The Film Combustion of Liquid Fuel", Z. Angew. Math. Mech. 13, 85 (1956).

E14. H. W. EMMONS, "Fire in the Forest," Fire Research Abstracts \& Reviews 5, $163(1963)$.

E15. H. W. EMMONS, "Fundamental Problems of the Free Burning Fire," 10th Int. Symp. Combustion, 951 (1964).

E16. H. W. EMmONS, S.-J. Ying, "The Fire Whir1," 11th Int. Symp. Combustion, 475 (1966).

E17. H. W. EMMONS, "Fluid Mechanics and Combustion," 13th Int. Symp. Combustion, 1 (1970).

E18. H. W. EMMONS, T. Shen, "Fire Spread in Paper Arrays," 13th Int. Symp. Combustion, 917 (1970).

E19. H. W. EMMONS, "Heat Transfer in Fire," ASME J. Heat Transfer 95C, 145 (1973).

E20. H. W. EMMONS, "Fire," in Proc. 8th U.S. National Congress of Applied Mechanics, Los Angeles, June 1978.

E21. H. W. EMMONS, "The Prediction of Fires in Buildings," 17th Int. Symp. Combustion, 1101 (1978). 
E22. H. W. EMMONS, "Scientific Progress on Fire," Ann. Rev. Fluid Mech. 12, 223 (1980).

E23. N. H. ETHRIDGE, AD-A050312, Blast Diffraction Loading on the Front and Rear Surfaces of a Rectangular Parallelepiped, Sept. 1977.

F01. J. B. FANG, F. R. Steward, "Flame Spread Through Randomly Packed Fue 1 Particles," Combustion Flame 13, 392 (1969).

F02. D. I. FEINSTEIN, W. F. Heuge1, M. L. Kardatzke, A. Weinstock, AD-842573, Personne1 Casualty Study, July 1968.

F03. F. E. FENDELL, AD-653250, Asymptotic Treatment of Premixed Flame Structure with Diffusion, Dec. 1966 .

F04. F. E. FENDELL, D. Coats, AD-654836, Natura1-Convection Flow Above a Point Heat Source in a Rotating Environment, 1967.

F05. F. E. FENDELL, AD-672130, Flame Structure in Initially Unmixed Reactants Under One-Step Kinetics, May 1967.

F06. F. E. FENDELL, AD-682055, Laminar Natural Convection About an Isothermally Heated Sphere at Small Grashof Number, Nov. 1967.

F07. F. E. FENDELL, D. E. Coats, E. B. Smith, AD-682600, Compressible Slow Viscous Flow Past a Vaporizing Droplet, April 1968.

F08. F. E. FENDELL, AD-757084, Tropical Cyclones, March 1973.

F09. F. E. FENDELL, AD-A107706, Analytic Modeling of Severe Vortical Storms, Oct. 1981 .

F10. C. C. FENG, W. A. Sirignano, "Further Calculations Based Upon a Theory of Flame Spread Across Solid Fuels," Combustion Flame 29, 247 (1977).

F11. A. FERNANDEZ-PELLO, F. A. Williams, "Laminar Flame Spread Over PMMA Surfaces," 15th Int. Symp. Combustion, 217 (1974).

F12. A. C. FERNANDEZ-PELLO, "Downward Flame Spread Under the Influence of Externally Applied Thermal Radiation," Combust. Sci. Tech. 17, 1 (1977).

F13. A. C. FERNANDEZ-PELLO, "Upward Laminar Flame Spread Under the Influence of Externa1ly Applied Thermal Radiation," Combust. Sci. Tech. 17, 87 (1977).

F14. A. C. FERNANDEZ-PELLO, R. J. Santoro, "On the Dominant Mode of Heat Transfer in Downward Flame Spread," 17th Int. Symp. Combustion, 1201 (1978). 
F15. A. C. FERNANDEZ-PELLO, "A Theoretical Model for the Upward Laminar Spread of Flames Over Vertical Fuel Surfaces," Combustion Flame 31, 135 (1978).

F16. A. C. FERNANDEZ-PELLO, "Flame Spread in a Forward Forced Flow," Combustion Flame 36, 63 (1979).

F17. W. J. FLATHAU, R. A. Breckendridge, C. K. Wiehle, AD-B001855, Operation Plumbbob: Blast Loading and Response of Underground Concrete - Arch Protective Structures, June 1959.

F18. W. L. FONS, "Heating and Ignition of Small Wood Cylinder," Industrial and Engineering Chemistry 43, 2130 (1950).

F19. W. L. FONS, F. M. Sauer, W. Y. Pong, AD-223244L, Blast Effects on Forest Stands by Nuclear Weapons, Dec. 1957.

F20. W. L. FONS, "Rate of Combustion from Free Surfaces of Liquid Hydrocarbons," Combustion Flame 5, 283 (1961).

F21. W. L. FONS, H. B. Clements, P. M. George, "Scale Effects on Propagation Rate of Laboratory Crib Fires," 9th Int. Symp. Combustion, 860 (1962).

F22. W. L. FONS, C. P. Butler, H. D. Bruce, AD-465331L, Thermal Effects on Cellulosic Materials, July 1965.

F23. M. A. FOSBERG, C. A. O'De11, M. J. Schroeder, AD-640216, Some Characteristics of the Three-Dimensional Structure of Santa Ana Winds, 1966 .

F24. R. B. FOSTER, F. P. Hoeber, AD-A084390, Survival, Reconstitution and Recovery: U.S.-Soviet Asymmetries and U.S. Policy Options, Feb. 1980.

F25. W. H. FRANDSEN, "Fire Spread Through Porous Fuels from the Conservation of Energy," Combustion Flame 16, 9 (1971).

F26. W. H. FRANDSEN, R. C. Rothermel, "Measuring the Energy-Release Rate of a Spreading Fire," Combustion Flame 19, 17 (1972).

F27. S. FRANKENTHAL, L. Ashley, J. W. Carpenter, Y. M. Treve, S. B. Martin, AD-372868L, Ground Target Ignition by High Altitude Nuclear Detonations, Feb. 1966 (SRD).

F28. R. FRIEDMAN, "A Survey of Knowledge About Idealized Fire Spread Over Surfaces," Fire Research Abstracts and Reviews 10, 1 (1968).

F29. R. M. FRISTROM, AD-769528, Fire Research Abstracts and Reviews, Vo1. 7, Sept. 1965. 
F30. R. M. FRISTROM, AD-769529, Fire Research Abstracts and Reviews, Vol. 8, Sept. 1966.

F31. R. M. FRISTROM, AD-769530, Fire Research Abstracts and Reviews, Vo1.9, Sept. 1967.

F32. R. M. FRISTROM, AD-769534, Fire Research Abstracts and Reviews, Cumulative Index for Vol. 1-9.

F33. R. M. FRISTROM, "Combustion Suppression," Fire Research Abstracts and Reviews 9 , 125 (1967).

F34. R. M. FRISTROM, AD-769531, Fire Research Abstracts and Reviews, Vo1. 10, Sept. 1968.

F35. R. M. FRISTROM, AD-769532, Fire Research Abstracts and Reviews, Vol. 11, Sept. 1969.

F36. R. M. FRISTROM, AD-769533, Fire Research Abstracts and Reviews, Vol. 12, Sept. 1970 .

F37. R. M. FRISTROM, G. Fristrom, $A D-732481$, Fire Research Abstracts and Reviews, Vol. 13, No. 1, 1971.

F38. R. M. FRISTROM, G. Fristom, E. J. Whipple, AD-741439, Fire Research Abstracts and Reviews, Vol. 13, No. 2, 1971.

F39. R. M. FRISTROM, AD-747288, Fire Research Abstracts and Reviews, Vo1. 13, No. 3, 1971.

F40. R. M. FRISTROM, AD-758337, Fire Research Abstracts and Reviews, Vo1. 14, No. 1, 1972.

F41. R. M. FRISTROM, AD-758338, Fire Research Abstracts and Reviews, Vo1. 14, No. 2, 1972.

F42. R. M. FRISTROM, AD-769535, Fire Research Abstracts and Reviews, Vol. 14, No. 3, Sept. 1972.

F43. R. M. FRISTROM, AD-A025493, Fire Research Abstracts and Reviews, Vol. 15, No. I, 1973.

F44. R. M. FRISTROM, AD-A025494, Fire Research Abstracts and Reviews, Vo1. 15, No. 2, 1973.

F45. R. M. FRISTROM, AD-A025495, Fire Research Abstracts and Reviews, Vol. 15, No. 3, 1973.

F46. R. M. FRISTROM, AD-A040714, Fire Research Abstracts and Reviews, Vo1. 16, 1974 . 
F47. R. M. FRISTROM, AD-064189, Fire Research Abstracts and Reviews, Vol. 17, Nos. 1-3, 1975.

F48. R. M. FRISTROM, AD-A064190, Fire Research Abstracts and Reviews, Vol. 18, Nos. 1-3, 1976.

G01. B. GABRIELSEN, C. Wilton, K. Kaplan, AD-A014957, Response of Arching Walls and Debris from Interior Walls Caused by Blast Loading, Feb. 1975.

G02. B. GABRIELSEN, K. Kaplan, C. Wilton, J. Zaccor, AD-A031216, Blast/Fire Interaction, Blast Translation, and Toxic Gases, July 1976.

G03. B. L. GABRIELSEN, R. S. Tansley, G. Cuzner, AD-A086738, Upgrading of Existing Structures: Phase II, June 1980.

G04. W. L. GAMBLE, A. J. Hendron, J. D. Haltiwanger, N. M. Newmark, $\mathrm{AD}-387433 \mathrm{~L}$, Resistance and Behavior of Thick Reinforced Concrete Slabs Under Static and Dynamic Loads, Feb. 1968 (C-NSI).

G05. D. R. GARG, F. R. Steward, "Pilot Ignition of Cellulosic Materials Containing High Void Spaces," Combustion \& Flame 17, 287 (1971).

G06. C. A. GARRIS, S. L. Lee, "A Theory for Multiple Fire-Whir1 Formation," 14th Int. Symp. Combustion, 1063 (1972).

G07. M. G. GIBBONS, F. I. LAUGHRIDGE, J. R. Nichols, N. A. Krause, "Transmission and Scattering Properties of a Nevado Desert Atmosphere Under Cloudy Conditions," J.0.S.A. 52, 38 (1962).

G08. M. G. GIBBONS, AD-641481, Transmissivity of Atmosphere for Thermal Radiation from Nuclear Weapons, Aug. 1966.

G09. R. W. GILMER, C. Kennedy, AD-A023054, The Potential for Relocation of Population Under Threat of a Nuclear Attack, Jan. 1976.

G10. I. I. GLASS, S. K. Chan, H. L. Brode, AD-780382, Strong Planar Shock Waves Generated by Explosively Driven Spherical Implosions, Oct. 1973.

G11. I. GLASSMAN, J. G. Hansel, "Some Thoughts and Experiments on Liquid Fuel Spreading, Steady Burning and Ignitability in Quiescent Atmospheres," Fire Research Abstract and Reviews 10, 217 (1968).

G12. S. GLASSTONE, The Effects of Nuclear Weapons, 3rd ed., U.S. A.E.C., Washington, D. C., 1977.

G13. R. L. GOEN, R. M. Rodden, D. W. Goodrich, AD-839266, Critical Review of Cost-Effectiveness of Blast Shelters - Phase II, Apri1 1968.

G14. T. C. GOODALE, M. B. Hawkins, and A. B. Willoughby, AD-412733, Feasibility of Active Countermeasures for Thermal Radiation Effects of Nuclear Weapons, July 1963. 
G15. T. GOODALE, AD-723429, Effects of Air Blast on Urban Fires, Dec. 1970.

G16. T. GOODALE, AD-740820, An Attempt to Explore the Effect of High Blast Overpressure on the Persistence of Smouldering Combustion in Debris, Dec. 1971.

G17. T. GOODALE, $A D-740821$, The Ignition Hazard to Urban Interiors During Nuclear Attack Due to Burning Curtain Fragments Transported by Blast, Dec. 1971

G18. Yu. A. GoStInTSEV, S. S. Novikov, L. A. Sukhanov, "Vortex Structure of a Rapidly Propagating Fire," Combustion, Explosion, and Shock Waves 11 , 336 (1975).

G19. Yu. A. Gostintsev, L. A. Sukhanov, "Convective Column Above a Linear Fire in Homogenous Isothermal Atmosphere," Combustion, Explosion and Shock Waves 13,570 (1977).

G20. Yu. A. GOSTINTSEV, L. A. Sukhanov, "Interaction of Convective Columns Above Linear Sources of Heat," Combustion, Explosion and Shock Waves 14, 60 (1978).

G21. Yu. A. GOSTINTSEV, L. A. Sukhanov, "Interaction Between a Convective Column and a Wind Above a Linear Fire in a Polytropic Atmosphere," Combustion Explosion, and Shock Waves 14, 452 (1978).

G22. K. E. GOULD, AD-A038738, Combined Airblast and Incendiary Effects from Nuclear Weapons on Urban Areas, Aug. 1975.

G23. L. GOURE, AD-A039526, The Soviet Civil Defense Shelter Program, May 1977.

G24. H. E. GRAHAM, "Fire Whirlwinds," Bull. Am. Met. Soc. 36, 99 (1955).

G25. I. M. GRINBERG, A. A. Putnam, AD-448118L, A Model Study of the Interaction Effects of Mass Fires, Sept. 1964.

G26. D. E. GROCE, M. W. McKay, SAI-133-82-038-LJ, Historical Fires Bibliography, Feb. 1982.

G27. D. GROSS, "Experiments on the Burning of Cross Piles of Wood," J. National Bureau Standards 66C, 99 (1962).

G28. D. GROSS, J. J. Loftus, "Surface Flame Propagation on Cellulosic Materials Exposed to Thermal Radiation," J. National Bureau Standards $67 \mathrm{C}, 251$ (1963).

G29. D. GROSS, A. F. Robertson, "Experimental Fires in Enclosures," 10th Int. Symp. Combustion, 931 (1964). 
G30. J. GRUMER, A. Strasser, T. A. Kubala, AD-265634, Preliminary Report on Studies of Air Flows ino Uncontrolled Fires, Nov. 1961.

G31. J. GRUMER, A. Strasser, T. A. Kubala, E. B. Cook, AD-275418, Studies of Air Flows into Uncontrolled Fires, May 1962.

G32. J. GRUMER, A. Strasser, T. A. Kubala, E. B. Cook, AD-420053L, Studies of Air Flows into Uncontrolled Fires, Oct. 1963.

H01. C. M. HAALAND, M. T. Heath, AD-759416, Passive-Active Defense Studies for the Detroit Metropolitan Area, Dec. 1972.

H02. C. M. HAALAND, C. V. Chester, E. P. Wigner, AD-A026362, Survival of the Relocated Population of the U.S. After a Nuclear Attack, June 1976.

H03. R. G. HAHL, AD-A022630, DCPA Fire Research Bibliography, 1962-1975, Jan. 1976.

H04. R. W. HALL, AD-856859, Vulnerability of Local Transportation Systems Albuquerque, New Mexico, July 1969.

H05. J. R. HALLMAN, J. R. Welker, C. M. Sliepcevich, AD-D402870, Ignition of Polymers, May 1972.

H06. J. R. HALLMAN, J. R. Welker, C. M. Sliepcevich, "Polymer Surface Reflectance - Absorptance Characteristics," Polymer Engineering and Science 14, 717 (1974).

H07. J. R. HALLMAN, J. R. Welker, C. M. Sliepcevich, "Radiation Absorption for Polymers," Am. Chem. Soc., Div. Org. Coat. Plast., 171st Mtg., New York, April $197 \overline{6 .}$

H08. J. R. HALLMAN, J. R. Welker, C. M. Sliepcevich, "Ignition Times for Polymers," Polymer-Plastics Technology and Engineering 6, 1 (1976).

H09. J. D. HALTIWANGER, W. J. Ha11, N. M. Newmark, AD-A084661, Behavior of Restrained Two-Way Slabs, Feb. 1979:

H10. J. R. HALLMAN, J. R. Welker, C. M. Sliepcevich, "Radiation Absorption for Polymers: The Radiant Panel and Carbon Arcs as Radiant Heat Sources," J. Fire Flammability 9, 353 (1978).

H11. T. Z. HARMATHY, "A New Look at Compartment Fires," Fire Technology $\underline{8}$, $196,326(1972)$.

H12. T. Z. HARMATHY, "Closure to the Discussion of Compartment Fires," Fire Technology 10, 247 (1974).

H13. T. Z. HARMATHY, "The Role of Thermal Feedback in Compartment Fires," Fire Technology 11, 48 (1975). 
H14. J. A. HAVENS, H. T. Hashemi, L. E. Brown, J. R. Welker, "A Mathematical Model of the Thermal Decomposition of Wood," Combust. Sci. Tech. 5, 91 (1972).

H15. J. H. HEDGES, A. D. Baer, N. W. Ryan, "Pyrolysis and Ignitions of Polymers under Approximated Fire Conditions," 17th Int. Symp. Combustion, 1173 (1978).

H16. A. J. HENDRON, W. L. Gamble, J. D. Haltiwanger, N. M. Newmark, $\mathrm{AD}-837422$, Design of Cylindrical Reinforced Concrete Tunnel Liners to Resist Air Overpressures, June 1968.

H17. G. HESKESTAD, "Modeling of Enclosure Fires," 14th Int. Symp. Combustion, 1021 (1972).

H18. G. HESKESTAD, "Physical Modeling of Fire," J. Fire Flammability 6 , 253 (1975).

H19. G. HESKESTAD, M. A. Delichatsios, "The Initial Convective Flow in Fire," 17th Int. Symp. Combustion, 1113 (1978).

H20. H. L. HICKS, H. G. Ryland, AD-A096314, Practical Guide for Public Safety Crisis Relocation Planning, Sept. 1980 .

H21. J. E. HILL, AD-673703, Problems of Fire in Nuclear Warfare, Aug. 1961.

H22. C. J. HILADO, R. M. Murphy, "Screening Materials for Ignitability," Modern Plastics 55(10), 52 (1978).

H23. T. HIRANO, K. Sato, "Effects of Radiation and Convection on Gas Velocity and Temperature Profiles of Flames Spreading Over Paper," 15 th Int. Symp. Combustion, 233 (1974).

H24. T. HIRANO, S. E. Noreikis, T. E. Waterman, "Postulations of Flame Spread Mechanisms," Combustion Flame 22, 353 (1974).

H25. S. HORIUCHI, Architectural Fire Protection, Carnegie-Mellon Civil Eng. Dept. translation, 1972 .

H26. S. R. HORNING, D. C. Sachs, AD-013908, Air-Blast Loading Test on Structures, June 1953 (C-NSI).

H27. C. E. HORTON, D. C. Sachs, K. Kaplan, AD-524230, Airblast Phenomena, May 1972 (SRD).

H28. H. C. HOTTEL, C. C. Williams, "Transient Heat Flow in Organic Materials Exposed to High Intensity Thermal Radiation," Industrial and Engineering Chemistry 47, 1136 (1955). 
H29. H. C. HOTTEL, G. C. Williams, F. R. Steward, "The Modeling of Firespread Through a Fuel Bed," 10th Int. Symp. Combustion, 997 (1964).

H30. H. C. HOTTEL, G. C. Williams, G. K. Kwentus, "Fuel Preheating in Free-Burning Fires," 13th Int. Symp. Combustion, 963 (1970).

H31. K. G. HUFFMAN, J. R. Welker, C. M. Sliepcevich, AD-664724, Wind and Interaction Effects on Free-Burning Fires, Dec. 1967.

H32. M. K. HULL, C. A. O'De11, M. J. Schroeder, AD-634565, Critical Fire Weather Patterns: Their Frequency and Levels of Fire Danger, 1966.

I01. N. R. IWANKIW, "Thermal Effects on Load Capacity of Concrete Slabs," ASCE J. Structural Div. 105, 1417 (1979).

J01. J. F. JARRETT, AD 637765 , Fire Data from the Watts Riot: Results of Preliminary Analysis and Evaluation, May 1966.

J02. W. S. JEWELL, A. B. Willoughby, AD-286943L, A Study to Analyze and Improve Procedures for Fire Damage Assessment Following Nuclear Attack, Part I, Oct. 1960 .

J03. F. I. JOHN, T. 0. Passe11, AD-640626, Evaluation of Nuclear Weapon Thermal Threat, Aug. 1966.

J04. F. I. JOHN, from AD-822599, Determination of Critical Initial Fire Densities, Oct. 1967.

J05. R. E. JONES, S. B. Martin, R. H. Renner, AD-659981, Nuclear Weapon Burst Parameters Governing Urban Fire Vulnerability, May 1967.

J06. P. JOUlAIN, J. M. Most, Y. Fuseau, B. Sztal, "Influence of Coupled Convection, Conduction and Radiation Heat Transfer on the Burning of Plastics," 17th Int. Symp. Combustion, 1041 (1978).

K01. A. M. KANURY, P. L. Blackshear, "Some Considerations Pertaining to the Problem of Wood-Burning," Combust. Sci. Tech. 1, 339 (1970).

K02. A. M. KANURY, P. L. Blackshear, "On the Combustion of Wood, II: The Influence of Internal Convection on the Transient Pyrolysis of Cellulose," Combustion Sci. Tech. 2, 5 (1970).

K03. A. M. KANURY, "Ignition of Cellulosic Solids - A Review," in AD-758337, Fire Research Abstracts and Reviews 14(1), 24 (1972).

K04. A. M. KANURY, "Rate of Charring Combustion in a Fire," 14th Int. Symp. Combustion, 1131 (1972). 
K05. A. M. KANURY, (SRI), "Ignition of Cellulosic Solids: Minimum Surface Temperature Criterion," Comb. Sci. Tech. 9, 171 (1974).

K06. A. M. KANURY, "Modeling of Pool Fires with a Variety of Polymers," I5th Int. Symp. Combustion, 193 (1974).

K07. A. M. KANURY, (Notre Dame), "The Science and Engineering of Hostile Fires," Fire Research Abstracts and Reviews 18, 72 (1976).

K08. K. KAPLAN, AD 423739, Experimental Study of the Effect of Material Properties on Coupling of Explosion Energy, May 1963.

K09. K. KAPLAN, URS Corp., Effects of Topography in High Strength Shock Regions, Jan. 1965.

K10. K. KAPLAN, C. Wiehle, AD-362824L, Air Blast Loading in the High Shock Strength Region, Part I: Analys is and Correlation, Feb. 1965 (SFRD).

K11. K. KAPLAN, C. Wiehle, AD-464651L, Air Blast Loading in the High Shock Strength Region. Part II: Prediction Methods and Examples, Feb. 1965.

K12. K. KAPLAN, AD-387384L, Techniques for Predicting the Effects of Topography on Air Blast in Real Terrain, Jan. 1967 (C-NSI).

K13. K. KAPLAN, AD-822365L, Effects of Topography in the High-Shock-Strength Region, March 1967.

K14. K. KAPLAN, AD-827751L, The Meaning of Simultaneity of Detonation with Respect to the Application of Quantity-Distance Regulations, Nov. 1967.

K15. K. KAPIAN, V. W. Davis, AD-837984L, Effectiveness of Barricades: Review of Basic Information, June 1968.

K16. K. KAPLAN, AD-A051569, Effects of Terrain on Blast Prediction Methods and Predictions, Jan. $19 \overline{978 .}$

K17. K. KAPLAN, P. D. Price, AD-A072787, Accidental Explosions and Effects of Blast Leakage Into Structures, June 1979.

K18. B. KARLOVITCH, "Flame Stabilization in Fast Streams," 6th Int. Symp. Combustion, 941 (1956).

K19. T. KASHIWAGI, "A Study of Flame Spread Over a Porous Material Under External Radiation Fluxes," 15th Int. Symp. Combustion, 255 (1974).

K20. T. KASHIWAGI, "A Radiative Ignition Model of a Solid Fue1," Comb. Sci. Tech. 8, 225 (1974).

K21. T. KASHIWAGI, "Effects of Sample Orientation on Radiative Ignition," Combustion Flame 44, 223 (1982). 
K22. C. H. KEARNY, C. V. Chester, AD-A052913, Blast Tests of Expedient Shelters in the Dice Throw Event, March 1978 .

K23. C. H. KEARNY, ORNL-5037, Nuclear War Survival Skills, Sept. 1979.

K24. C. H. KEARNY, C. V. Chester, E. N. York, AD-A083966, Blast Tests of Expedient Shelters in the Misers Bluff Event, Jan. $19 \overline{80}$.

K25. J. H. KEEFER, G. T. Watson, G. A. Coulter, V. L. King, AD-A077117, Effects of Terrain on Blast Waves, Aug. 1979.

K26. J. A. KELLER, T. E. Lommasson, AD-817623, Survey of Fuel Arrays

Ignitable by a Nuclear Weapon Thermal Pulse in Albuquerque, N.M., March 1967.

K27. J. R. KELSO, W. S. Filler, K. Kaplan, AD-835629L, Barricaded vs. Unbarricaded Blast Pressure-Distance Relationships, July 1966.

K28. T. E. KENNEDY, AD-727678, The Dynamic Response of a Simulated Buried Arch to Blast Loading, July 1971 .

K29. T. E. KENNEDY, AD-528460L, Dynamic Response of Sma11 Shear Wall Structures, Project LN 316, Dial Pack Event, Aug. 1972.

K30. J. W. KERR, J. F. Christian, AD-662055, Civil Defense Fire Research Research Report No. 13, 1967.

K31. J. W. KERR, M. G. Gibbons, AD-823013L, 5th Annual OCD Fire Research Contractors Meeting, April 1967.

K32. J. W. KERR, AD-848661L, 6th Annual OCD Fire Research Contractors Meeting, April 1968.

K33. J. W. KERR, C. C. Buck, W. E. Cline, S. Martin, W. D. Nelson, AD-892866L, Nuclear Weapons Effects in a Forest Environment-Thermal and Fire, July 1971 .

K34. J. W. KERR, "Historic Fire Disasters," Fire Research Abstracts and Reviews 13 (1), 1 (1971).

K35. J. W. KERR, AD-902507L, 10th Annual DCPA Fire Research Contractors Meeting, April 1972.

K36. J. W. KERR, AD-914820L, 11th Annual DCPA Fire Research Contractors Meeting, April 1973 .

K37. J. W. KERR, AD-914820L, 197311 th Annual DCPA Fire Research Contractors Meeting, Asilomar, Calif., Aug. 1973. 
K38. J. W. KERR, AD-B000095L, DCPA All-Effects Research Contractors Meeting, April 1974, Pacific Grove, Calif., Oct. 1974.

K39. J. S. KIM, J. De Ris, F. W. Kroesser, "Laminar Free-Convective Burning of Fuel Surfaces," 13th Int. Symp. Combustion, 949 (1970).

K40. J. S. KIM, J. De Ris, F. W. Kroesser, "Laminar Burning Between Parallel Fuel Surfaces," Int. J. Heat Mass Transfer 17, 439 (1974).

K41. T. KINBARA, H. Endo, S. Sega, "Downward Propagation of Smoldering Combustion Through Solid Materials," 11th Int. Symp. Combustion, 525 (1966).

K42. A. N. KOOHYAR, J. R. Welker, C. M. Sliepcevich, "The Irradiation and Ignition of Wood by Flame," Fire Technology 4, 284 (1968).

K43. F. J. KOSDON, F. A. Williams, C. Buman, "Combustion of Vertical Cellulosic Cylinders in Air," 12th Int. Symp. Combustion, 253 (1968).

K44. L. KRISHNAMURTHY, F. A. Williams, "Laminar Combustion of PMMA in Oxygen-Nitrogen Mixtures," 14th Int. Symp. Combustion, 1151 (1972).

K45. H.-C. KUNG, "The Burning of Vertical Wooden Slabs," 15th Int. Symp. Combustion, 243 (1974).

K46. Y. KUROSAKI, A. Ito, M. Chiba, "Downward Flame Spread Along Two Vertical, Parallel Sheets of Thin Combustible Solid," 17th Int. Symp. Combustion, 1211 (1978).

K47. Y. KUROSAKI, N. Isshiki, A. Ito, T. Kashiwagi, "Downward Flame Spread Along a Vertical Sheet of Thin Combustible Solid," J. Fire Flammability 10,3 (1979).

K48. M. KUWATA, T. J. Kuo, R. H. Essenhigh, "Burning Rates and Operational Limits in a Solid-Fuel Bed," in ASME Proc. 1970 National Incinerator Conf., 272 (1970).

L01. W. G. LABES, "The E1lis Parkway and Gary Dwelling Burns," Fire Technology 2, 287 (1966).

L02. W. G. LABES, AD-642243, Fire Department Operations Analysis, Sept. 1966.

L03. W. G. LABES, T. E. Waterman, R. B. Varley, AD-650323, Development of Standard Fire Test Rating Systems for Shelter Components, Dec. 1966.

L04. W. G. LABES, AD-674435, Fire Department Operations Analys is, Jan. 1968.

L05. W. B. LANE, H. Lee, AD-673855, Effects of Mass Fires on Fallout Deposition, Feb. 1968. 
L06. P. D. LA RIVIERE, H. Lee, AD-815846, Postattack Recovery of Damaged Urban Areas, Nov. 1966.

L07. D. A. LARSON, R. D. Sma11, (PSR Note 360) Large Area Fire - An Analytic Model, Dec. 1980.

L08. F. A. LASTRINA, R. S. Magee, R. F. McAlevy, "Flame Spread Over Fue1 Beds: Solid-Phase Energy Considerations," 13th Int. Symp. Combustion, 935 (1970).

L09. K. P. LAUGHLIN, AD-611227, Thermal Ignition and Response of Materials, Dec. 1957.

L10. D. I. LAWSON, D. L. Simms, "The Ignition of Wood by Radiation," Brit. J. Appl. Phys., 3, 288 (1952).

L11. B. T. LEE, AD-701956, Mass Fire Scaling with Small Electrically Heated Models, May 1969.

L12. B. T. LEE, AD-715413, Laboratory Scaling of the Fluid Mechanical Aspects of Mass Fires, Aug. 1970.

L13. B. T. LEE, AD-731503, Modeling the Dynamic Behavior of Building Fires, Aug. 1971.

L14. B. T. LEE, AD-751610, Modeling Individual and Multiple Building Fires, Aug. 1972 .

L15. B. T. LEE, "Laboratory Scaling of the Fluid Mechanical Aspects of Large Fires," Combust. Sci. Tech. 4, 233 (1972).

L16. C. K. LEE, R. F. Chaiken, J. M. Singer, "Charring Pyrolys is of Wood in Fires by Laser Simulation," 16th Int. Symp. Combustion, 1459 (1976).

L17. C. K. LEE, J. R. Dieh1, "Combustion of Irradiated Dry and Wet Oak," Combustion Flame 42, 123 (1981).

L18. H. LEE, AD-690859, Industrial Recovery Mode1 Constraints, Oct. 1968.

L19. S.-L. LEE, H. W. Emmons, "A Study of Natural Convection Above a Line Fire," J. Fluid Mech. II, 353 (1961).

L20. S.-L. LEE, C.-H. Ling, "Natural Convection Plume Above a Circular Ring Fire," 1lth Int. Symp. Combustion, 501 (1966).

L21. S. -L. LEE, "Axisymmetric Turbulent Swirling Natural Convection Plume, Part 1--Theoretical Investigation," Trans. ASME 33E, 647 (1966).

L22. S.-L. LEE, "Axisymmetrical Turbulent Swirling Natural Convection Plume, Part 2--Experimental Investigation," Trans. ASME 33E, 656 (1966). 
L23. S.-L. LEE, C. A. Garris, "Formation of Multiple Fire Whirls," 12th Int. Symp. Combustion, 265, 1968 .

L24. S.-L. LEE, J. M. Hellman, "Firebrand Trajectory Study Using an Empirical Velocity-Dependent Burning Law," Combustion Flame 15, 265 $(1970)$.

L25. S.-L. LEE, F. W. Otto, "Gross Vortex Activities in a Simple Simulated Urban Fire," 15th Int. Symp. Combustion, 157 (1974).

L26. S.-L. LEE, "Fire Research," App1. Mech. Rev. 25, 502 (1972).

L27. K. A. LINCOLN, "Flash-Pyrolysis of Solid Fuel Materials by Thermal Radiation," Pyrodynamics 2, 133 (1965).

L28. A. E. LIPSKA, AD-658717, Isothermal Degradation of Untreated and Fire Retardant Cellulose at $350^{\circ} \mathrm{C}, \mathrm{Feb} .1967$.

L29. A. E. LIPSKA, F. Wodley, AD-676351, Isothermal Pyrolys is of Cellulose Kinetics and Analysis of Degradation Products, March 1968.

L30. A. E. LIPSKA, AD-715411, The Effect of Flame Retardants on Thermal Degradation of Alpha-Cellulose in Nitrogen, Aug. 1970.

L31. A. E. LIPSKA, S. B. Martin, AD-734438, The Effect of Flame Retardants on Thermal Degradation of Alpha-Cellulose in Nitrogen, Aug. 1971.

L32. A. E. LIPSKA, A. J. Amaro, AD-A014492, Development and Evaluation of Practical and Self-Help Fire Retardants, April 1975.

L33. T. E. LOMMASSON, AD-827029, Fire Casualty Study, June 1964.

L34. T. E. LOMMASSON, AD-636794, Preliminary Investigation of Firestorm Start-Criteria, June 1965.

L35. T. E. LOMMASSON, J. A. Kel1er, R. G. Kirkpatrick, AD-813565, Firestorm Analysis, Feb. 1967.

L36. T. E. LOMMASSON, J. A. Keller, from AD-822599, A Macroscopic View of Fire Phenomenology and Mortality Prediction, 0ct. 1967.

L37. T. E. LOMMASSON, "A General 'Firestorm' Existence and Buildup Hypothesis," in AD-870088L, Mass Fire Symposium, Canberra, Australia, Feb. 1969.

L38. A. LONGINOW, AD-655284, Civil Defense Shelter Options for Fallout and Blast Protection (Dual-Purpose), May 1967.

L39. A. LONGINOW, O. J. Stepanek, AD-674663, Civil Defense Shelter Options for Fallout and Blast Protection (Single-Purpose), June 1968. 
L40. A. LONGINOW, J. Kalinowski, C. A. Kot, F. Salzberg, AD-740174, Civil Defense Shelter Options: Deliberate Shelters, Vol. 1, Dec. 1971 .

L41. A. LONGINOW, J. Kalinowski, C. A. Kot, F. Salzberg, AD-740175, Civil Defense Shelter Options: Deliberate Shelters, Vol. 2, Dec. 1971.

L42. A. LONGINOW, G. Ojdrovich, L. Bertram, A. Wiedermann, AD-764114, People Survivability in a Direct Effects Environment and Related Topics, May $\overline{1973 .}$

L43. A. LONGINOW, E. Hahn, A. Wiedermann, S. Citko, AD-A011108, Casualties Produced by Impact and Related Topics of People Survivability in a Direct Effects Environment, Aug. 1974.

L44. A. LONGINOW, A. Wiedermann, S. Citko, N. Iwankiw, AD-A030815, Debris Motion and Injury Relationships in All Hazard Environments, July 1976.

L45. A. LONGINOW, A. Widermann, AD-A049040, Relative Structura1 Considerations for Protection from Injury and Fatality at Various Overpressures, June 1977.

L46. A. LONGINOW, E. E. Hahn, L. A. Bertram, "Personnel Survivability in Blast Wind Environment," ASCE J. Eng. Mechanics 103, 311 (1977).

L47. A. LONGINOW, AD-A055764, Survivability in Crisis-Upgraded Shelters, Feb. 1978.

L48. A. LONGINOW, AD-A062752, Survivability on the Fringe of High Risk Areas, Oct. 1978.

L49. A. LONGINOW, AD-A076026, Survivability in a Nuclear Weapon Environment, May 1979.

L50. A. LONGINOW, AD-A087600, Probability of People Survival in a Nuclear Weapon Blast Environment, May 1980.

L51. A. LONGINOW, R. P. Joyce, AD-A092688, Load Tests of a Wood Floor Over a Basement, June 1980 .

L52. A. LONGINOW, K.-H. Chu, N. T. Thomopoulos, "Probability of Survival in Blast Environment," ASCE J. Eng. Mechanics 108, 309 (1982).

M01. S. E. MAGNUSSON, S. Thelanderson, "A Division of Compartment Fires," Fire Technology 10, 228 (1974).

M02. J. A. MALTHAN, AD-A020938, DNA Master File of Ground-Shock, Air-Blast, and Structure-Response Data: Vol. 1: Archive Description and User's Information, Nov. 1975 .

M03. G. H. MARKSTEIN, J. De Ris, "Upward Spread Over Textiles," 14th Int. Symp. Combustion, 1085 (1972). 
M04. G. H. MARKSTEIN, "Radiative Properties of Plastics Fires," 17th Int. Symp. Combustion, 1053 (1978).

M05. R. E. MARTIN, D. W. Pendleton, W. Burgess, "Effect of Fire Whirlwind Formation on Solid Fuel Burning Rates," Fire Technology 12, 33 (1976).

M06. S. MARTIN, C. P. Butler, W. B. Plum, AD-221535L, Thermal Radiation Damage to Cellulosic Materials, Part I: Wood, Aug. 1954 .

M07. S. B. MARTIN, W. Lai, AD-203419L, Thermal Radiation Damage to Cellulosic Materials, Part III: Ignition of Alpha Cellulose by Pulses Simulating Nuclear Weapon Air Bursts, May 1958.

M08. S. MARTIN, K. A. Lincoln, R. W. Ramstad, AD-216545, Thermal Radiation Damage to Cellulosic Materials, Part IV: Influence of Moisture Content and the Radiant Absorptivity of Cellulosic Materials on their Ignition Behavior, Dec. 1958 .

M09. S. B. MARTIN, AD-226429, A Simple Radiant Heating Method for Determining the Thermal Diffusivity of Cellulosic Materials, April 1959.

M10. S. MARTIN, AD-231330L, On Predicting the Susceptibility of Typical Kindling Fuels to Ignition by the Thermal Radiation from Nuclear Detonations, April 1959.

M11. S. B. MARTIN, R. W. Ramstad, AD-227642, Temperature Profiles in Thermally Irradiated Cellulose Accompanying Its Spontaneous Ignition, May 1959.

M12. S. B. MARTIN, $A D-414174$, Ignition of Cellulosic Kindling Fuels by Very Brief Radiant Pulses, July 1963 .

M13. S. B. MARTIN, AD-449236L, Diffusion-Controlled Ignition of Organic Solids by Intense Radiant Energy, April 1964.

M14. S. B. MARTIN, AD-449601L, Ignition-Ablation Responses of Cellulosic Materials to High Radiant Heat Loads, 1964.

M15. S. B. MARTIN, "Ignition of Organic Materials by Radiation," in Fire Research Abstracts and Reviews 6 (1964).

M16. S. MARTIN, "Diffusion-Controlled Ignition of Cellulosic Materials by Intense Radiant Energy," 10th Int. Symp. Combustion, 877 (1964).

M17. S. B. MARTIN, R. W. Ramstad, AD-458764, Stable Pyrolysis Products of Cellulose Exposed to Intense Thermal Radiation, Jan. 1965.

M18. S. B. MARTIN, S. Holton, AD-619416, Preliminary Computer Program for Estimating Primary Ignition Ranges for Nuclear Weapons, June 1965. 
M19. S. B. MARTIN, "Ignition-Ablation Responses of Cellulosic Materials to High Radiant Heat Loads," Pyrodynamics 2, 145 (1965).

M20. S. B. MARTIN, N. J. Alvares, AD-484521L, Ignition Thresholds for I.arge-Yield Nuclear Weapons, April 1966.

M21. S. B. MARTIN, R. H. Renner, R. E. Jones, AD-818882, Fundamental Processes of Ignition and Combustion Relating to Fires Caused by Nuclear Detonations, March 1967.

M22. S. B. MARTIN, R. H. Renner, R. E. Jones, AD-659982, Application of Fire Fundamentals to Models of Macroscale Phenomena from Nuclear Weapon Bursts, July 1967 .

M23. S. B. MARTIN, M. Staackmann, R. W. Ramstad, AD-674121, Fire-Service Capabilities for Damage Control and Rescue, March 1968.

M24. S. B. MARTIN, M. Staackmann, R. W. Ramstad, AD-837697, Supplementary Analysis of Fire-Service Capabilities for Damage Control and Rescue, March 1968.

M25. S. MARTIN, R. Ramstad, C. Colvin, AD-690965, Development and Application of an Interim Fire-Behavior Model, April 1968.

M26. S. MARTIN, R. Ramstad, C. Colvin, AD-855723, Fire Damage to San Jose in the Five-City Attack (Appendix C to Development and Application of an Interim Fire-Behavior Mode1), April 1968.

M27. S. MARTIN, R. Ramstad, C. Colvin, AD-855724, Development and Application of an Interim Fire-Behavior Model, Appendix D: Fire Damage to New Orleans in the Five-City Attack, April 1968.

M28. S. B. MARTIN, R. W. Ramstad, AD-695382, Capabilities of Fire Services to Limit Damage from Nuclear Attack, May 1969.

M29. S. B. MARTIN, R. W. Ramstad, T. Goodale, C. A. Start, AD-695383, Effects of Air Blast on Urban Fire Response, May 1969.

M30. S. B. MARTIN, AD-716326, Civil Defense Test Design and Support of Operation Flambeau-Type Fires, Aug. 1970.

M31. S. B. MARTIN, AD-923461L, The Role of Fire in Nuclear Warfare: An Interpretive Review of the Current Technology for Evaluating the Incendiary Consequences of the Strategic and Tactical Uses of Nuclear Weapons, Aug. 1974.

M32. S. B. MARTIN, C. J. Cook, T. Goodale, AD-A003929, Shocktube for Blast-Fire Interaction Studies, Aug. 1974.

M33. S. B. MARTIN, M. P. Fricke, S. J. Wiersma, M. K. Drake, AD-A047572, The Impact of Fires Produced by Tactical Nuclear Weapons, Dec. 1976. 
M34. S. B. MARTIN, R. S. Alger, AD-A064316, Blast/Fire Interactions: Program Formulation, Oct. 1978.

M35. S. B. MARTIN, S. J. Wiersma, (SRI 非YC 6496) An Experimental Study of Flashover Criteria for Compartment Fires, April 1979 .

M36. S. B. MARTIN, AD-A085663, Experiments on Extinction of Fires by Airblast: Flame Displacement as an Extinction Mechanism, May 1980 .

M37. S. B. MARTIN, AD-A095956, Shocktube for Blast/Fire Interaction Studies, Aug. 1980.

M38. S. B. MARTIN, R. G. McKee, (SRI \#6935) Fire Tests for Exterior Wall Materials: Fire Transmission over Building Facades, Sept. 1980.

M39. S. B. MARTIN, R. S. Alger, J. R. Rempe1, P. S. Hughes, AD-A094074, Blast/Fire Interactions: Analys is of Parametric Sensitivity and Large-Scale Experimental Determination of Ignition Thresholds, oct. 1980 .

M40. S. B. MARTIN, R. S. Alger, AD-A104394, Blast/Fire Interaction: Asilomar Conference, April 1981.

M41. H. MASON, D. Wa1ter, AD-688186, An Exploratory Study to As sess the Magnitude of OCD Foundation Problems, Nov. 1968.

M42. R. F. McAlEVY, R. S. Magee, "The Mechanism of Flame Spreading Over the Surface of Igniting Condensed Phase Materials," 12th Int. Symp. Combustion, 215 (1968).

M43. J. MCAULIFFE, K. Mo11, AD-625173, Secondary Ignitions in Nuclear Attack, July 1965.

M44. R. J. MCCARTER, A. Broido, "Radiative and Convective Energy from Wood Crib Fires," Pyrodynamics 2, 65 (1965).

M45. J. T. McGILL, L. A. Schmidt, H. M. Pitcher, L. P. Dolins, J. Bracken, $\mathrm{AD}-753015$, Methodologies for Evaluating the Vulnerability of National Systems, Vol. 1: Methodologies and Examples, June 1972.

M46. J. H. McGUIRE, P. G. Smith, P. H. Thomas, AD-307419L, Correlation of Field and Laboratory Tests on the Exposure of Fabrics to Radiation, March 1959 (C-NSI).

M47. J. F. MELICHAR, $A D-672476$, The Propagation of Blast Waves into Chambers, March 1968.

M48. J. P. MELLEGERS, AD-869727, Branden Tengevolge van Nucleaire Explosives (Met eeen Literatuuroverzicht samengesteld door A. Meulen) [Fires Caused by Nuclear Explosives (with a Bibliography by A. Meulen)], Oct. 1969 .

M49. M. L. MERRITT, AD-459098, Air Shock Pressures as Affected by Hills and Dales, Sept. 1954. 
M50. A. G. MERZHANOV, A. E. Averson, "The Present State of the Thermal Ignition Theory: An Invited Review," Combustion \& Flame 16, 89 (1971).

M51. F. A. MIERCORT, AD-774619, Description of a Fast-Running Fire-Spread Mode1, Dec. 1973.

M52. C. F. MILLER, J. W. Kerr, AD-632366, Field Notes on World War II German Fire Experience, Oct. 1965.

M53. C. MILLER, AD-664523, Wor1d War II German Fire Document Translations, July 1967.

M54. C. MILLER, AD-672497, Summary of Damage by Air Raids on City of Hamburg, July 1968.

M55. C. MILLER, AD-680459, Police Reports on Large Scale Air Attacks on Hamburg, Germany, Appendices 1-7, Dec. 1968.

M56. C. MILLER, AD-681075, Police Reports on Large Scale Air Attacks on Hamburg, Germany, Appendices 8-19, Dec. 1968.

M57. C. F. MILLER, AD-711021, Assessment of Nuclear Weapon Requirements for Assured Destruction, Feb. 1970 .

M58. C. F. MILLER, AD-726461, Fire Fighting Operations in Hamburg, Germany During World War II, June 1971.

M59. C. F. MILLER, AD-753346, Fire Fighting Operations in Hamburg, Germany During World War II: Excerpts from the Hamburg Fire Department Documents on the Attacks During World War II, Appendices 3-5, and Photographs, April 1972.

M60. C. F. MILLER, AD-787042, Constraints on Civil Defense Operations in Physically Damaged Areas, Feb. 1973.

M61. H. MILLER, AD-801306L, Thermal Radiation Effects on Paints, Plastics, and Coated Fabrics, July 1952 .

M62. R. I. MILLER, T. 0. Passe11, AD-404028, Radiative Energy Transfer from Nuclear Detonations Above 50-km Altitude, April 1963.

M63. R. K. MILLER, M. E. Jenkins, J. A. Keller, AD-716807, Analysis of Four Models of the Nuclear-Caused Ignitions and Early Fires in Urban Areas, Aug. 1970.

M64. J. E. MINOR, A. J. Pryor, G. E. Commerford, R. C. DeHart, AD-862194L, Evaluation of Industrial Systems Interrelationships and Vulnerability to Nuclear Attack, Nov. 1969 . 
M65. K. K. MOHANTY, J. M. Ottino, H. T. Davis, "Reaction and Transport in Disordered Composite Media: Introduction of Percolation Concepts," Chem. Eng. Sci. 37, 905 (1982).

M66. K. MOLL, J. McAuliffe, AD-679898, Public Capabilities for Preventing and Extinguishing Ignitions from Nuclear Attack, Nov. 1968.

M67. B. R. MORTON, G. I. Taylor, J. S. Turner, "Turbulent Gravitational Convection from Maintained and Instantaneous Sources," Proc. Roy. Soc. 24A, 1 (1956).

M68. B. R. MORTON, "Buoyant Plumes in a Moist Atmosphere, J. Fluid Mech. $\underline{2}$, 127 (1957).

M69. B. R. MORTON, "Forced Plumes," J. Fluid Mech. 5, 151 (1959).

M70. B. R. MORTON, "Modeling Fire Plumes," 10th Int. Symp. Combustion, 973 (1964).

M71. B. R. MORTON, "Geophysical Vortices," in Prog. in Aeronautical Sciences 7. $145(1966)$.

M72. B. R. MORTON, "Entrainment Models for Laminar Jets, Plumes, and Wakes," Phys. Fluids 10, 2120 (1967).

M73. B. R. MORTON, "The Physics of Fire Whir1s," Fire Research Abstracts and Reviews 12, 1 (1970).

M74. N. A. MOUSSA, T. Y. Toong, C. A. Garris, "Mechanism of Smoldering of Cellulosic Materials," 16th Int. Symp. Combustion, 1447 (1976).

M75. M. P. MURGAI, H. W. Emmons, "Natural Convection Above Fires," J. Fluid Mech. 8,611 (1960).

M76. M. P. MURGAI, "Radiative Transfer Effects in Natural Convection Above Fires," J. Fluid Mech. 12, 441 (1962).

M77. M. P. MURGAI, R. K. Varma, "Radiative Transfer Effects in Natural Convection Above Fires--Transparent Approximation, Ambient Atmosphere Nonisothermal," Int. J. Heat Mass Trans. 8, 833 (1965).

M78. M. P. MURGAI, R. K. Varma, "Radiative Transfer Effects in Natural Convection Above Fires--Opaque Approximation," Q. Appli. Math. 22, 345 (1965).

M79. M. P. MURGAI, R. K. Varma, S. K. Bahl, "Natural Convection Above Two Axi-symmetric Fires," Combustion Flame 10, 240 (1966).

M80. A. MURASZEW, J. B. Fedele, W. C. Kuby, "The Fire Whir1 Phenomena," Combustion Flame 34, 29 (1979). 
M81. M. P. MURGAI, Natural Convection from Combustion Sources, (Oxford and IBH Pub1. Co.: New Delhi, Bombay, and Calcutta, India), 1976.

M82. M. P. MURGAI, Similarity Analysis in Fire Research, With Special Reference to Fire Convection Inside Enclosures, Oxford \& IBH Pub1. Co., New Delhi, Bombay, Calcutta (1976).

M83. H. L. MURPHY, J. R. Rempel, J. E. Beck, AD-A023237, Slanting in New Basements for Combined Nuclear Weapons Effects, A Consolidated Printing of Four Technical Reports; Volumes 1, 2, 3, Oct. 1975.

M84. H. L. MURPHY, C. K. Wiehle, E. E. Pickering, AD-A030762, Upzrading Basements for Combined Nuclear Weapons Effects: Expedient Options, May 1976.

M85. H. L. MURPHY, J. E. Beck, AD-A039499, Maximizing Protection in New EOCS from Nuclear Blast and Related Effects: Guidance Provided by Lecture and Consultation, Sept. 1976.

M86. K. A. MURTY, P. L. Blackshear, "Pyrolysis Effects in the Transfer of Heat and Mass in Thermally Decomposing Organic Solids," 11th Int. Symp. Combustion, 517 (1966).

M87. N. MUTOH, T. Hirano, K. Akitas, "Experimental Study on Radiative Ignition of PMMA," 17th Int. Symp. Combustion, 1183 (1978).

N01. A. NAKAKUKI, "Flame Spread Over Solid and Liquid Fuels," J. Fire Flammability 7, 19 (1976).

N02. National Academy of Sciences, NAS 非86, International Symposium on the Use of Models in Fire Research, 1961.

N03. R. L. NEVIN, AD-859227L, Vulnerability of the Albuquerque Water Supply System, June 1969 .

N04. N. M. NEWMARK, J. W. Briscoe, J. L. Merritt, AD-298347, Analysis and Design of Flexible Underground Structures, Oct. 1962.

N05. N. M. NEWMARK, J. D Haltiwanger, AD-29408, Air Force Design Manual. Principles and Practices for Design of Hardened Structures, Dec. 1962.

N06. N. M. NEWMARK, W. H. Walker, R. J. Mosberg, AD-632805, Response Spectra of Multi-Degree-of-Freedom Elastic Systems. Supplement: A Computer Program for Computation of Dynamic Structural Response, April 1965.

N07. N. M. NEWMARK, W. H. Walker, A. S. Veletsos, R. J. Mosborg, AD-627870, Response of Two-Degree-of-Freedom Elastic and Inelastic Systems, Dec. 1965. 
N08. N. M. NEWMARK, W. H. Walker, R. J. Mosborg, AD-627516, Response Spectra of Multi-Degree-of-Freedom Elastic Systems, Dec. 1965.

N09. N. M. NEWMARK, W. J. Hall, J. D. Haltiwanger, A. J. Hendron, A. H. S. Ang, AD-867906, Ground Motion Technology Review, April 1970.

N10. N. M. NEWMARK, AD-917813L, Effect of Height of Burst on Horizontal Yielding Targets, March 1974.

N11. H. J. NIELSEN, L. Tao, L. Wolf, AD-415680, Analysis of Convection Column Above a Fire Storm, Aug. 1963.

N12. H. J. NIELSEN, L. N. Tao, "The Fire Plume Above a Large Free-Burning Fire," 10th Int. Symp. Combustion, 965 (1964).

N13. H. J. NIELSEN, AD-618711, Fire Storm Environmental Model, April 1965.

N14. H. J. NIELSEN, AD-642866, Equipment Design for Test of Fire Storm Environmental Mode1, May 1966.

N15. H. NIELSEN, AD-701927, Origin and Properties of Fire Whirls, Aug. 1969.

N16. H. J. NIELSEN, AD-864418L, Mass Fire Data Analysis, Jan. 1970.

N17. T. NIIOKA, F. A. Williams, "Relationship Between Theory and Experiment for Radiant Ignition of Solids," 17 th Int. Symp. Combustion, 1163 (1978).

N18. Z. NIZAMUDDIN, B. Bresler, "Fire Response of Reinforced Concrete Slabs," ASCE J. Structural Div. 105, 1653 (1979).

O01. OFFICE OF CIVIL DEFENSE, AD-707932, Fire Aspects of Civil Defense, July 1968.

002. T. J. OHLEMILLER, M. Summerfield, "Radiative Ignition of Polymeric Materials in Oxygen/Nitrogen Mixtures," 13th Int. Symp. Combustion, 1087 (1970).

003. K. O. OPALKA, (ARBRL-TR-02385) A Simple Model for Predicting the Blast Loading of Box-Like Structures, Dec. 1981.

004. L. ORLOFF, J. De Ris, "Modeling of Ceiling Fires," 13th Int. Symp. Combustion, 979 (1970).

005. L. ORLOFF, J. De Ris, G. H. Markstein, "Upward Turbulent Fire Spread and Burning of Fuel Surface," 15th Int. Symp. Combustion, 183 (1974). 
006. L. ORLOFF, A. T. Modak, R. L. Alpert, "Burning of Large-Scale Vertical Surfaces," 16th Int. Symp. Combustion, 1345 (1976).

007. M. G. ORTIZ-MOLINA, T.-Y. Toong, N. A. Moussa, G. C. Tesoro, "Smoldering Combustion of Flexible. Polyurethane Foams and Its Transition to Flaming or Extinguishment," 17 th Int. Symp. Combustion, 1191 (1978).

P01. P. J. PAGNI, T. G. Peterson, "Flame Spread Through Porous Fuels," 14th Int. Symp. Combustion, 1099 (1972).

P02. P. J. PAGNI, T. M. Shih, "Excess Pyrolyzate," 16th Int. Symp. Combustion, 1329 (1976).

P03. T. Y. PALMER, AD-710980, Project Flambeau: An Investigation of Mass Fire (1964-1967), Vol. II, Catalogue of Project Flambeau Fires, 1969.

P04. T. Y. PALMER, "Absorption by Smoke Particles of Thermal Radiation in Large Fires," J. Fire Flammability, I, 460 (1976).

P05. T. Y. PALMER, "Large Fire Winds, Gases and Smoke," Atmospheric Environment 15, 2079 (1981).

P06. W. J. PARKER, AD-635250, Thermal Hardening Considerations Pertaining to Residential Areas, Feb. $1 \overline{966 .}$

P07. W. J. PARKER, AD-667236, Urban Mass Fire Scaling Considerations, Oct. 1967.

P08. W. PARKER, R. C. Corlett, B. T. Lee, AD-679902, Experimental Test of Mass Fire Scaling Principles, July 1968.

P09. W. J. PARKER, A. E. Lipska, AD-701957, A Proposéd Model for the Decomposition of Cellulose and the Effect of Flame Retardants, May 1969.

P10. T. O. PASSELL, AD-404590, Transmission by the Earth's Atmosphere of Thermal Energy from Nuclear Detonations Above $50-\mathrm{km}$ Altitude, April 1963.

P11. R. K. PEFLEY, J. F. Abe1, J. S. Dutton, AD-753843, Physiological Effects of Low Ventilation Rates, High Temperatures and High Humidities, June 1972.

P12. R. K. PEFLEY, D. M. Be11, G. H. Shiomoto, AD-A021509, Physiological Response to Fire Induced Heat Environments, Jan. 1976.

P13. R. K. PEFLEY, J. T. MacDonald, AD-A056253, The Use of the Physiological Thermal Index (PTI) as an Alternate to Effective Temperature for Civil Defense Planning, Nov. 1977.' 
P14. D. L. PETERSEN, L. A. Schmidt, AD-717552, Arrangements of U.S. Population by Urban and Rura1 Geometrical Clusters, Sept. 1970.

P15. P. V. PHUNG, A. B. Willoughby, AD-613359, Prediction Models for Fire Spread Following Nuclear Attack, Jan. 1965.

P16. P. V. PHUNG, A. B. Willoughby, "Prediction Models for Fire Spread," Pyrodynamics 2, 39 (1965).

P17. E. E. PICKERING, J. L. Bockholt, AD-738558, Probabilistic Air Blast Failure Criteria for Urban Structures, Nov. 1971.

P18. 0. A. PIPKIN, C. M. Sliepcevich, "Effect of Wind on Buoyant Diffusion Flames," Ind. Eng. Chem. Fundamentals 3, 147 (1964).

P19. J. PRAHL, H. W. Emmons, "Fire Induced Flow Through an Opening," Combust. Flame 25, 369 (1975).

P20. A. J. PRYOR, C. M. Vi11, AD-642790, Mass Fire Life Hazard, Sept. 1966.

P21. A. J. PRYOR, G. E. Commerford, J. E. Minor, AD-832264, Vulnerability of Industries Critical to National Survival in a Postattack Environment, Jan. 1968 .

P22. A. PRYOR, F. A. Fear, R. J. Wheeler, AD-672035, Mass Fire Life Hazard, March 1968.

P23. A. PRYOR, D. E. Johnson, N. N. Jackson, AD-697839, Hazards of Smoke and Toxic Gases Produced in Urban Fires, Sept. 1969.

P24. A. A. PUTNAM, C. F. Speich, AD-270055L, A Model Study of the Interacting Effects of Mass Fires, Nov. 1961.

P25. A. A. PUTNAM, C. F. Speich, "A Model Study of the Interaction of Multiple Turbulent Diffusion Flames," 9 th Int. Symp. Combustion, 867 (1962).

P26. A. A. PUTNAM, C. F. Speich, AD-419429, A Model Study of the Interaction Effects of Mass Fires, March 1963.

P27. A. A. PUTNAM, "Area Fire Considered as Perimeter-Line Fire," Combustion Flame 7, 305 (1963).

P28. A. A. PUTNAM, "A Model Study of Wind-Blown Free-Burning Fires," 10th Int. Symp. Combustion, 1039 (1964).

Q01. J. G. QUINTIERE, B. J. McCaffrey, K. Den Braven, "Experimental and Theoretical Analysis of Quasi-Steady Small-Scale Enclosure Fires," 17th Int. Symp. Combustion, 1125 (1978).

Q02. J. G. QUINTIERE, "An Approach to Modeling Wall Fire Spread in a Room," Fire Safety Journal 3 , 201 (1981). 
R01. J. W. REED, (Sandia, SC-RR-65-0369) Air Blast Yield Scaling in Refracting Atmospheres, July 1965.

R02. J. R. REMPEL, D. N. Schmidt, J. D. Erkman, W. M. Isbe11, AD-628796, Shock Attenuation in Solid and Distended Materials, Feb. 1966.

R03. J. R. REMPEL, AD-832639, Ground Shock and the Survival of the Contents of Personnel Shelters. Resistance of Human and Inanimate Contents of Hardened Shelters to Nuclear-Induced Ground Motion, May 1968.

R04. J. R. REMPEL, C. K. Wiehle, AD-A060798, Collateral Air Blast Damage, Apri1 1978.

R05. J. R. REMPEL, AD-C020643, Collateral Airblast Danage, April 1979 $(\mathrm{C}-\mathrm{NSI})$.

R06. J. REMPEL, AD-A089170, Debris Distribution as a Parameter in Blast/Fire Interaction, June 1980.

R07. J. R. REMPEL, AD-A104669, Debris Distribution as a Parameter in Blast/Fire Interaction, June 1981 .

R08. R. H. RENNER et al., Thermal Calculation for the Five Cities Study, Dec. 1965, (NRDL) (SFRD).

R09. R. H. RENNER, S. B. Martin, R. E. Jones, AD-645051, Parameters Governing Urban Vulnerability to Fire from Nuclear Bursts (Phase 1), June 1966.

R10. R. H. RENNER R. Jones, AD-384147L, Countermeasures Limiting Urban Vulnerability to Fire from Nuclear Bursts, April 1967.

R11. A. F. ROBERTS, "An Analogue Method of Estimating Wood Pyrolysis Rates," 11th Int. Symp. Combustion, 561 (1966).

R12. R. M. RODDEN, F. I. John, R. Laurino, AD-616638, Exploratory Analysis of Fire Storms, May 1965.

R13. R. M. RODDEN, AD-479980, Significant Primary Fires from Nuclear Detonations, Jan. 1966.

R14. J. C. ROGERS, AD-410031L, Ignition of Materials by Large-Yield Nuclear Weapons for Various Burst Heights and Atmospheric Conditions, May 1963.

R15. J. C. ROGERS, T. Miller, AD-344518, Survey of the Thermal Threat of Nuclear Weapons, July 1963 (SRD).

R16. R. C. ROTHERMEL, PB-210095, A Mathematical Model for Predicting Fire Spread in Wildland Fuels, Jan. 1972.

R17. J. ROTZ, J. E. Edmunds, K. Kaplan, AD-614924, Effects of Fire on Structural Debris Produced by Nuclear Blast, Jan. 1965. 
R18. J. ROTZ, J. E. Edmunds, K. Kaplan, AD-614925, Effects of Fire on Structural Debris Produced by Nuclear Blast, Jan. 1965.

R19. J. ROTZ, J. E. Edmunds, K. Kaplan, AD-615156, Effects of Fire on Structural Debris Produced by Nuclear Blast, May 1965.

R20. J. ROTZ, J. Edmunds, K. Kaplan, $A D-635187$, Formation of Debris from Buildings and Their Contents by Blast and Fire Effects of Nuclear Weapons, April 1966.

R21. J. ROTZ, AD-822061, Debris Model Research with Building Damage, Fire Spread, and Debris Predictions for Five-City Study, March 1967.

R22. J. ROTZ, AD-672060, Detailed Damage Analysis of NFSS Structures with Detailed Descriptions of Damage and Degraded Protection Factors, Sept. 1967.

S01. D. C. SACHS, S. R. Hornig, AD-043119, Airblast Loading on Structures, July 1954 (C-NSI).

S02. D. C. SACHS, L. M. Swift, F. M. Sauer, AD-617182, Airblast Overpressure and Dynamic Pressure Over Various Surfaces, Sept. $195 \%$.

S03. D. C. SACHS, B. S. Evans, AD-379032, A Review of the 'State of the Art' of Nuclear Blast (and the Synergistic Effects of Other Phenomena), Addendum No. 1, Nov. 1966 (SRD).

S04. D. C. SACHS, AD-507421L, Air Blast from Sub-Kiloton Nuclear Explosions, June 1969.

S05. D. C. SACHS, R. E. Keefe, P. A. Ellis, P. B. Wells, E. A. Bathke, AD-513571, Blast and Thermal Lethality, Nov. 1970 (SRD).

S06. D. C. SACHS, P. B. We11s, AD-523823L, Nuclear Weapons Blast Phenomena, Vol. I: Source and Development of Blast Waves in Air, Supplement 1: Air Blast Environments from Special Nuclear Weapons, July 1972 (SRD).

s07. D. C. SACHS, J. R. Keith, AD-C022186, Handbook for Late-Time Assessment of Target Damage from Nuclear Bursts, April 1979 (SFRD).

S08. M. S. SAHOTA, P. J. Pagni, "Temperature Fields in Structural Elements Subject to Fires," ASME J. Heat Transfer 97C, 598 (1975).

S09. M. S. SAHOTA, P. J. Pagni, "Heat and Mass Transfer in Porous Media Subject to Fires," Int. J. Heat Mass Transfer 22, 1069 (1979).

S10. F. SALZBERG, W. G. Labes, H. Nielsen, T. E. Waterman, AD-326102, Prediction of Fire Damage to Installation and Built-Up Areas from Nuclear Weapons, Phase II: Study of Ignition and Spread of Fires in Typical Structures, December 1960. 
S11. F. SALZBERG, A. Takata, W. G. Labes, AD-323265L, Prediction of Fire Damage to Installations and Built-up Areas from Nuclear Weapons Phase I: Literature Survey, 1961 .

S12. F. SAlZBERG, G. L. Maatman, J. F. Volvarka; AD-601341, An Approach to Trans-Attack Fire Suppression in Urban Areas, March 1964.

S13. F. SALZBERG, A. J. Pintar, F. J. Vodvarka, AD-635492, Description of Urban Areas for Fire Analysis, March 1965.

S14. F. SAlZBERG, M. M. Gutterman, A. J. Pintar, AD-468300L, Prediction of Fire Damage to Installations and Built-Up Areas from Nuclear Weapons, Phase III: Theoretical Studies, July 1965.

S15. F. SALZBERG, AD-645466, Design of Test for Simulating Urban Area Burns, June 1966.

S16. F. SALZBERG, T. E. Waterman, "Studies of Building Fires with Models," Fire Technology 2, 196 (1966).

S17. F. SALZBERG, AD-688206, Feasibility and Representativeness of Large-Scale Boxcar Burns, Oct. 1968 .

S18. F. SALZBERG, AD-712342, Fire Department Operations Analys is, June 1970.

S19. J. C. SANDERLIN, J. A. Ba11, G. A. Johanson, (DNA-5803F) Mass Fire Model Concept, May 1981.

S20. F. M. SAUER, C. C. Chandler, K. Arnold, AD-018183L, Primary Ignitions Following Atomic Attack on Urban Targets - Transient Exterior Fuels, June 1953.

S21. F. M. SAUER, K. Arnold, W. L. Fons, C. C. Chandler, AD-460310, Ignition and Persistent Fires Resulting from Atomic Explosions - Exterior Kindling Fuels, Dec. 1953.

S22. F. M. SAUER, W. Lai, AD-083508L, Convective Heating of Air Above an Inorganic Surface Heated by Radiation from a Nuclear Weapon, Nov. 1955.

S23. F. M. SAUER, AD-255430, Comparison of Field and Laboratory Forest Fuel Ignition Energies and Extrapolation to High-Yield Weapons, March 1956.

S24. F. M. SAUER, AD-222070L, The Charring of Wood During Exposure to Thermal Radiation. Correlation Analysis for Semi-Infinite Solids, Aug. 1956.

S25. F. M. SAUER, AD-607288, Ignition of Black Alpha-Cellulose Papers by Thermal Radiation, Square Wave Pulse, Sept. 1956. 
S26. F. M. SAUER, G. B. Clark, D. C. Anderson, AD-443593L, Nuclear Geoplosics, A Sourcebook of Underground Phenomena and Effects of Nuclear Explosives, Part IV: Empirical Analysis of Ground Motion and Cratering, May 1964.

S27. F. M. SAUER, AD-375820L, Forest Blowdown, Comparison of Swedish Experiments and U.S. Predictions-An Interim Study, Aug. 1966 (S-NSI).

S28. F. M. SAUER, J. R. Rempe1, B. Barclay, C. T. Vincent, AD-389829L, Earth Pressure and Motion Measurements, May 1968 (SRD).

S29. F. M. SAUER, AD-857292L, Forest Blowdown-Comparison of the Results of High-Explosive Experiments and Predictions, July 1969.

S30. F. M. SAUER, AD-B047873L, Nuclear Airblast Precursor Dynamic Pressures Related to Surface Parameters, March 1980.

S31. S. SCESA, F. M. Sauer, AD-062835L, Possible Effects of Free Convection on Fire Behavior; Laminar and Turbulent Line and Point Sources of Heat, Sept. 1954.

S32. L. A. SCHMIDT, F. B. Porzel, AD-323560, Surface Effects on Blast Loadings, May 1958.

S33. L. A. SCHMIDT, F. B. Porzel, AD-323609L, Surface Effects on Blast Loadings, May 1958.

S34. L. A. SCHMIDT; F. B. Porze1, AD-323610L, Surface Effects on Blast Loadings, May 1958.

S35. L. A. SCHMIDT, AD-617149, Study of Drag Loading of Structures in the Precursor Zone, Jan. 1959.

S36. L. A. SCHMIDT, AD-719242, A Study of National Travel Requirements for Strategic Evacuation, March 1970 .

S37. L. A. SCHMIDT, AD-728139, A Sensitivity Analysis of Urban Blast Fatality Calculations, Jan. 1971.

S38. L. SCHMIDT, AD-751547, Analytic Mode1s of Nationwide Urban Fatalities from a Nuclear Attack, July 1972.

S39. L. A. SCHMIDT, AD-787614, The Use of the ADAGIO Computer Program in Strategic Evacuation Analysis, Oct. 1974.

S40. L. A. SCHMIDT, AD-A022242, Methodology of Fallout-Risk Assessment, Jan. 1975.

S41. L. A. SCHMIDT, AD-A022799, Interactive ADAGIO Computer Program as an Aid to Crisis Relocation Planning, Nov. 1975. 
S42. L. A. SCHMIDT, AD-A040945, Documentation of Current IDA Computer Material Developed for DCPA, Vol. 1, Jan. 1977.

S43. L. A. SCHMIDT, AD-A039819, Documentation of Current IDA Computer Material Developed for DCPA, Vol. 2, Jan. 1977.

S44. L. A. SCHMIDT, AD-A039820, Documentation of Current IDA Computer Material Developed for DCPA, Vol. 3, Jan. 1977.

S45. L. A. SCHMIDT, AD-A068502, Analytical Representations of Blast Damage for Several Types of Targets, Oct. 1978.

S46. L. A. SCHMIDT, AD-A081387, A Parametric Study of Probabilistic Fire Spread Effects, Sept. 1979.

S47. L. A. SCHMIDT, AD-A094517, Development of Civil Defense Damage Assessment Programs, Nov. 1980 .

S48. L. A. SCHMIDT, AD-A104993, A Study of Twenty-Four Nationwide Fallout Patterns from Twelve Winds, Sept. 1981.

S49. J. J. SHEA, AD-668342, Blast Casualty Prediction - Past, Present, and Future, April 1968.

S50. W. E. SHELBERG, S. B. Martin, AD-203168, An Exploratory Study of Protection Against Nuclear Thermal Radiation with Smoking and Intumescent Paints, June 1958.

S51. W. SHELBERT, E. Tracy, AD-661458, Urban Mass Fires from Nuclear Weapon Attack, Aug. 1967.

S52. F. H. SHELTON, B. S. Evans, D. C. Sachs, AD-348867L, A Study of Air Blast Phenomenology in the Very High Pressure Region, Dec. 1962 (SRD).

S53. F. H. SHELTON, D. C. Sachs, P. A. E11 is, B. S. Evans, AD-346028, Theoretical Study of Early Blast-Thermal Behavior of Nuclear Explosions, Feb. 1963 (SRD).

S54. U. K. SHIVADEV, H. W. Emmons, "Thermal Degradation and Spontaneous Ignition of Paper Sheets in Air by Irradiation," Combustion Flame 22, 223 (1974).

S55. M. SIBULKIN, A.. G. Hansen, "Experimental Study of Flame Spreading Over a Horizontal Fue1 Surface," Combust. Sci. Tech. 10, 85 (1975).

S56. M. SIBULKIN, J. Kim, "The Dependence of Flame Propagation on Surface Heat Transfer II: Upward Burning," Combust. Sci. Tech. 17, 39 (1977). 
S57. M. SIBULKIN, A. K. Kulkarni, K. Annama1ai, "Effects of Radiation on the Burning of Vertical Fuel Surfaces," 18 th Int. Symp. Combustion, 611 (1980).

S58. D. L. SIMMS, M. Law, P. L. Hinkley, R. W. Pickard, FWE-188, Tripartite Conference on Effect of Atomic Weapons: Ignition of Materials by Thermal Radiation, August 1957.

S59. D. L. SIMMS, "Ignition of Cellulosic Materials by Radiation," Combustion Flame 4 , 293 (1960)

S60. D. L. SIMMS, "Experiments on the Ignition of Cellulosic Materials by Thermal Radiation," Combustion Flame 5, 369 (1961).

S61. D. L. SIMMS, "On the Pilot Ignition of Wood by Radiation," Combustion Flame 7, 253 (1963).

S62. D. L. SIMMS, M. Law, "The Ignition of Wet and Dry Wood by Radiation," Combustion Flame 11, 377 (1967).

S63. G. K. SINNAMON, J. D. Haltiwanger, N. M. Newmark, AD-357972L, Effect of Length of Positive Phase of Blast on Drag-Type and Semidrag-Type Industrial Buildings, Aug. 1959 (S-FRD).

S64. W. A. SIRIGNANO, I. Glassman, "Flame Spreading Above Liquid Fuels: Surface-Tension Driven Flows," Combustion Sci. Tech. 1,307 (1970).

S65. W. A. SIRIGNANO, "Theory of Flame Spread Above Solids," Acta Astronautica 1, 1285 (1974).

S66. R. D. SMALL, H. L. Brode, AD-A086328, Physics of Large Urban Fires, March 1980.

S67. R. D. SMALL, H. L. Brode, AD-A108730, Methodology for Predicting Urban Fire Damage From Nuclear Bursts, Dec. 1980 .

S68. R. D. SMALL, D. A. Larson, H. L. Brode, AD-A108730, Analys is of Large Urban Fires, Sept. 1981.

S69. J. B. SMITH, E. W. Cousins, R. M. Newman, AD-600261, Fire Hazard to Fallout Shelter Occupants: A Classification Guide, April 1964.

S70. J. B. SMITH, E. W. Cousins, M. J. Miller, R. M. Newman, AD-610819, Fire Safety Upgrading for Fallout Shelters in Buildings, Nov. 1964.

S71. R. K. SMITH, "Radiation Effects on Large Fire Plumes," 11th Int. Symp. Combustion, 507 (1966).

S72. R. K. SMITH, B. R. Morton, L. M. Leslie, "The Role of Dynamic Pressure in Generating Fire Wind," J. Fluid Mech. 68, 1 (1975). 
S73. D. B. SPALDING, "The Combustion of Liquid Fuels, "4th Int. Symp. Combustion, 847 (1952).

574. D. B. SPALDING, "The Art of Partial Modeling," 9th Int. Symp. Combustion, 833 (1962).

S75. D. B. SPALDING, "The Burning Rate of Liquid Fuels from Open Trays by Natural Convection," Fire Research Abstracts and Reviews 4, 234 (1962).

S76. L. V. SPENCER, AD-456269L, Project Harbor: Report of Pane1 on Immediate Surviva1, 1965.

S77. M. STAACKMANN, AD-855897, AD-857600, AD-857601, AD-857602, AD-857623, Damage to and Analysis of Fire Department Capabilities, March 1969.

S78. P. S. STARRETT, "Factors Influencing Flame Spread Rates in Solid Materials," J. Fire Flammability 8, 5 (1977).

S79. A. E. STEVENSON, D. A. Schermerhorn, S. C. Miller, "Simulation of Southern California Forest Fires," 15th Int. Symp. Combustion, 147 (1974).

S80. F. R. STEWARD, "Linear Flame Heights for Various Fuels," Combustion Flame $\underline{8}, 171,(1964)$.

S81. F. R. STEWARD, "Prediction of the Height of Turbulent Diffusion Buoyant Flames," Combust. Sci. Tech. 2, 203 (1970).

S82. F. R. STEWARD, "A Mechanistic Fire Spread Model," Combust. Sci. Tech. 4, 177 (1971).

S83. F. R. STEWARD, "Ignition Characteristics of Cellulosic Materials," in Heat Transfer in Fires, edited by P. L. Blackshear, John Wiley (New York), 1974.

S84. F. R. STEWARD, "Heat Transfer in Fires," 6th Int. Heat Transfer Conference, Toronto, 1978, p. 451.

S85. F. R. STEWARD, K. N. Tennankore, "The Measurement of the Burning Rate of an Individual Dowel in a Uniform Fuel Matrix," 18th Int. Symp. Combustion, 641 (1980).

S86. T. G. STOREY, A. F. Bush, J. J. Leonard, W. H. Yundt, AD-710981, Project Flambeau: An Investigation of Mass Fire (1964-1967), Vol. III: Appendices, 1969.

S87. T. G. STOREY, J. H. Dieterich, AD-634042, Fire Bibliography: Selected Urban and Mixed Urban-Rural Fires, 1940-1964, May 1965. 
S88. J. D. STRODE, J. E. Cockayne, C. R. Thomas, W. P. Boquist, A. A. Burns, AD-B047839L, Proceedings of the Misers Bluff Phase II Results Symposium, Vol. III, Sept. 1979.

S89. G. W. STUART, AD-399935L, Theoretical Study of the Effects of Very Large Yields Above the Atmosphere, August 1961.

S90. I. R. STUBBS, K. L. Benuska, AD-625866, Documentation of Computer Program for Evaluation of Building Fire Resistance, Jan. 1964.

S91. I. R. STUBBS, $A D-625040$, Blast and Impact Exposure of Existing Structural Fire Protection Schemes, June 1965.

S92. J. P. STUMBAR, M. Kuwata, T. J. Kuo, R. H. Essenhigh, "Propagation Velocity and Flame Spread Through Simulated Fuel Beds," ASME 4th National Incinerator Conf., Cincinnati, May 1970, 288.

S93. L. M. SWIFT, D. C. Sachs, AD-134700, Airblast Loading on Structures, Aug. 1956 (C-NSI).

S94. L. M. SWIFT, D. C. Sachs, AD-337904, Air-Blast Phenomena as Affected by Terrain, Dec. 1957.

S95. L. M. SWIFT, D. C. Sachs, F. M. Sauer, AD-491310, Ground Acceleration, Stress, and Strain at High Incident Overpressures, May 1960.

T01. A. N. TAKATA, F. Salzberg, AD-684874, Development and Application of a Complete Fire-Spread Model: Vol. I (Development Phase), June 1968.

T02. A. N. TAKATA, F. Salzberg, AD-849732, Development and Application of a Complete Fire-Spread Model: Vol. II (Application to Detroit), June 1968.

T03. A. N. TAKATA, F. Salzberg, AD-849733, Development and Application of a Complete Fire-Spread Model: Vol. III (Application to Albuquerque), June 1968.

T04. A. N. TAKATA, F. Salzberg, AD-849734, Development and Application of a Complete Fire-Spread Model, Vol. IV: Application to San Jose, June 1968 .

T05. A. N. TAKATA, AD-688941, Mathematical Modeling of Fire Defenses, Part I, March 1969.

T06. A. TAKATA, AD-695636, Power Density Rating for Fire in Urban Areas, April 1969.

T07. A. N. TAKATA, AD-705388, Mathematical Modeling of Fire Defenses, Part II, March 1970.

T08. A. N. TAKATA, AD-719731, Fire Spread in High Density High-Rise Buildings, Feb. 1971. 
T09. A. N. TAKATA, T. E. Waterman, AD-743210, Fire Laboratory Tests - Phase II: Interaction of Fire and Simulated Debris, Feb. 1972.

T10. A. N. TAKATA, AD-753989, Fire Spread Model Adaptation, Oct. 1972.

T11. R. S. TANSLEY, J. V. Zaccor, AD-A110919, Testing of She1ter Design and Industrial Hardening Concepts at the Mill Race Event, Jan. 1982.

T12. C. S. TARIFA, P. P. del Notario, F. G. Moreno, "On the Flight Paths and Lifetimes of Burning Particles of Wood," 10th Int. Symp. Combustion, 1021 (1964).

T13. C. S. TARIFA, A. M. Torralbo, "Flame Propagation Along the Interface Between a Gas and a Reacting Medium," 11th Int. Symp. Combustion, 533, (1966).

T14. C. S. TARIFA, P. P. del Notario, A. M. Torralbo, "On the Process of Flame Spreading Over the Surface of Plastic Fuels in an Oxidizing Atmosphere," 12th Int. Symp. Combustion, 229 (1968).

T15. A. TEWARSON, "Some Observations on Experimental Fires in Enclosures, Part I: Cellulosic Materia1s," Combustion Flame 19, 101 (1972).

T16. A. TEWARSON, "Heat Release Rates from Burning Plastics," J. Fire Flammability 8,115 (1977).

T17. P. H. THOMAS, C. T. Webster, M. M. Raftery, "Some Experiments on Buoyant Diffusion Flames," Combustion Flame 5, 359 (1961).

T18. P. H. THOMAS, "The Size of Flames from Natural Fires," 9 th Int. Symp. Combustion, 844 (1962).

T19. P. H. THOMAS, R. Baldwin, A. J. M. Heselden, "Buoyant Diffusion Flames: Some Measurements of Air Entrainment, Heat Transfer, and Flame Merging," 10th Int. Symp. Combustion, 983 (1964).

T20. P. H. THOMAS, A. J. M. Heselden, M. Law, AD-664875, Fully-developed Compartment Fires -- Two Kinds of Behavior, October 1967.

T21. P. H. THOMAS, "Some Aspects of the Growth and Spread of Fire in the Open," Forestry 40, 139 (1967).

T22. P. H. THOMAS, AD-909430L, Theoretical Considerations of the Growth to Flashover of Compartment Fires, Dec. 1967.

T23. P. H. THOMAS, A. J. M. Heselden, M. Law, AD-664875, Fully Developed Compartment Fires--Two Kinds of Behavior, 1967.

T24. P. H. THOMAS, "Rates of Spread in Some Wind-Driven Fires," Forestry 44, 156 (1971). 
T25. P. H. THOMAS, "Behavior of Fires in Enclosures -- Some Recent

Progress," 14th Int. Symp. Combustion, 1007 (1972).

T26. P. H. THOMAS, "Self-Heating and Thermal Ignition--A Guide to Its Theory and Application," in Ignition, Heat Release, and Noncombustibility of Materials, ASTM STP502, Am. Soc. Testing Materials, 1972.

T27. P. H. THOMAS, "An Approximate Theory of 'Hot Spot' Criticality," Combustion Flame 21, 99 (1973).

T28. P. H. THOMAS, "Fires in Enclosures," in Heat Transfer in Fires, edited by P. L. Blackshear, John Wiley \& Sons (New York), 1974.

T29. P. H. THOMAS, "O1d and New Looks at Compartment Fires," Fire Technology $11,42(1975)$.

T30. P. H. THOMAS, "Fire Modeling and Fire Behavior in Rooms," 18th Int. Symp. Combustion, 503 (1980).

T31. P. H. THOMAS, M. L. Bullen, J. G. Quintiere, B. J. McCaffrey, "Flashover and Instabilities in Fire Behavior," Combustion Flame 38 , 159 (1980).

T32. P. THOMPSON, Compressible Fluid Dynamics, McGraw-Hi11 (New York), 1972.

T33. E. R. TINNEY, "The Combustion of Wooden Dowels in Heated Air," 10th Int. Symp. Combustion, 925 (1964).

T34. R. TODD, (Sandia, SC-3335-TR) A Scale-Model Study of the Effects of Symmetric Ridges on Blast Overpressures, May 1954.

T35. TRIPARTITE TECHNICAL COOPERATION PROGRAM, PANEL N3 (THERMAL RADIATION), AD-822599L, Mass Fire Research Symposium, Oct. 1967.

T36. TRIPARTITE TECHNICAL CO-OPERATION PROGRAM, PANEL N2, WORKING GROUP J, AD-870088L, Canberra Mass Fire Symposium, Vol. I, Feb. 1969.

T37. TRIPARTITE TECHNICAL CO-OPERATION PROGRAM, PANEL N2, WORKING GROUP J, AD-870089L, Canberra Mass Fire Symposium, Vol. II, Feb. 1969.

T38. G. E. TROXELL, J. K. Degenkolb, K. L. Benuska, B. R. Loya, AD-625867, Reusability of Buildings After a Warfire, Jan. 1964.

T39. Y. TSUCHIYA, K. Sumi, "Computation of the Behavior of Fire in an Enclosure," Combustion Flame 16, 131 (1971).

T40. J. S. TURNER, "The Constraints Imposed on Tornado-Like Vortices by the Top and Bottom Boundary Conditions," J. Fluid Mech. 25, 377 (1966). 
V01. R. B. VAILE, WT-1424-1, Operation Plumbbob: Project 3.5a, Isolation of Structures from Ground Shock, April 1962.

V02. W. H. VAN HORN, AD-733359, Postattack Recovery and Operation Parameters Affecting Debris Estimatiơn Procedures, June 1971.

V03. R. B. VARLEY, G. L. Maatman, AD-449386L, Shelter Fire Vulnerability Specific Fire Limiting Activities for Occupants, Sept. 1964.

V04. R. B. VARLEY, G. L. Maatman, AD-615391, Shelter Fire Vulnerability Survey and Analys is of Representative Buildings, March 1965.

V05. A. VARMA, F. R. Steward, "Spontaneous Ignition of High Voidage Cellulosic Materials," J. Fire Flammability 1 , 154 (1970).

V06. R. K. VARMA, M. P. Murgai, "Natural Convection Above Fires--An Analytical Solution," Trans. ASME 37E, 850 (1970).

V07. A. S. VELETSOS, N. M. Newmark, AD-444989, Response Spectra of Single-Degree-of-Freedom Elastic and Inelastic Systems, June 1964.

V08. C. T. VINCENT, J. R. Rempe1, AD-385137L, Close-In Stress Measurements, Nov. 1967 (C-FRD).

V09. F. J. VODVARKA, T. E. Waterman, AD-618414, Fire Behavior - Ignition to Flashover, June 1965.

V10. F. J. VODVARKA, F. Salzberg, AD-697271, Ful1-Scale Burns in Urban Areas - Shelter Experiments, June 1969.

V11. F. J. VODVARKA, AD-711122, Ful1-Scale Burns in Urban Areas, Part I: Fire Spread Between Structures, June 1969 .

V12. F. J. VODVARKA, AD-704725, Firebrand Field Studies, Sept. 1969.

V13. F. J. VODVARKA, AD-707454, Urban Burns - Ful1-Scale Field Studies, Jan. 1970 .

V14. M. VOGEL, F. A. Williams, "Flame Propagation Along Matchstick Arrays," Combust. Sci. Tech. 1,429 (1970).

V15. R. J. VYAS, J. R. Welker, "End-Grain Ignition of Wood," J. Fire Flammability 6 , 355 (1975).

W01. N. R. WALLACE, A. B. Willoughby, AD-272596, Effects of Topography on Dynamic Pressure, Oct. 1961.

W02. T. E. WATERMAN, W. G. Labes, F. Salzberg, J. E. Tanney, F. J. Vodvarka, AD-661851, Prediction of Fire Damage to Installations and Built-up Areas from Nuclear Weapons, Phase III: Experimental Studies Appendices A-G, Nov. 1964. 
W03. T. E. WATERMAN, F. J. Vodvarka, AD-815879L, The Ignition of Materials by High Yield Weapons, March 1965.

W04. T. E. WATERMAN, AD-648641, Determination of Fire Conditions Supporting Room Flashover, Sept. 1966.

W05. T. E. WATERMAN, AD-637806, Shelter Habitability in Existing Buildings Under Fire Exposure, June 1966.

W06. T. E. WATERMAN, AD-829884L, Scaling of Fire Conditions Supporting Room Flashover, Dec. 1967.

W07. T. WATERMAN, AD-695640, Experimental Study of Firebrand Generation, Jan. 1969.

W08. T. E. WATERMAN, A. N. Takata, AD-697270, Laboratory Study of Ignition of Host Materials by Firebrands, June $196 \overline{9}$.

W09. T. E. WATERMAN, AD-713017, Fire Laboratory Tests, Phase I, Sept. 1970.

W10. T. E. WATERMAN, AD-D401687, Fire Behavior of Combustible Interior Finish Materials, May 1971.

W11. T. E. WATERMAN, AD-723424, Scaled Room Flashover: Apri1 1971.

W12. T. E. WATERMAN, AD-D401687, Fire Behavior of Combustible Interior Finish Materials, May 1971 .

W13. T. E. WATERMAN, "Room Flashover--Criteria and Synthesis," Fire Technology 4, 25 (1968).

W14. T. E. WATERMAN, "Room Flashover--Model Studies," Fire Technology $\underline{8}, 316$ (1972).

W15. T. E. WATERMAN, AD-759514, Fire Laboratory Tests -- Phase III: Fire in Blast-Initiated Debris External to Shelters, Feb. 1973.

W16. T. E. WATERMAN, AD-786175, Fire Laboratory Tests - Effects of Barrier Integrity and Fire Ventilation on Shelter Habitability, May 1974.

W17. T. E. WATERMAN, AD-A001134, Experimental Structural Fires, July 1974.

W18. W. D. WEATHERFORD, D. M. Sheppard, "Basic Studies of the Mechanism of Ignition of Cellulosic Materials," 10th Int. Symp. Combustion, 897 (1964).

W19. W. D. WEATHERFORD, M. L. Valtierra, "Piloted Ignition of Convection-Heated Cellulose Slabs," Combustion Flame 10, 279 (1966). 
W20. L. W. WEISBECKER, H. Lee, AD-713418, Evaluation of Systems of Fire Development, Aug. 1970.

W21. J. R. WELKER, C. M. S1iepcevich, AD-607279, A Low Speed Wind Tunnel for Measuring the Effect of Wind on Buoyant Diffusion Flames, Sept. 1964.

W22. J. R. WELKER, 0. A. Pipkin, C. M. Sliepcevich, "The Effect of Wind on Flames," Fire Technology 1, 122 (1965).

W23. J. R. WELKER, C. M. Sliepcevich, AD-474283, The Effect of Wind on Flames (Continuation Study), Nov. 1965.

W24. J. R. WELKER, C. M. Sliepcevich, "Bending of Wind-Blown Flames from Liquid Pools," Fire Technology 2, 127 (1966).

W25. J. R. WELKER, AD-875925L, Susceptibility of Potential Target Components to Defeat by Thermal Action, Sept. 1969.

W26. J. R. WELKER, "The Pyrolysis and Ignition of Cellulosic Materials, A Literature Review," J. Fire Flammability 1, 12 (1970).

W27. J. R. WELKER, C. M. Sliepcivich, AD-736395, Heat Transfer by Direct Flame Contact Fire Test, Phase I, July 1971.

W28. P. B. WELLS, J. R. Keith, D. C. Sachs, W. J. Veigele, AD-383799, Investigation of Air Blast from Special Weapons, Feb. 1967 (SRD).

W29. P. B. WELLS, J. R. Keith, R. E. Wellck, D. C. Sachs, AD-500418L, Air Blast from Special Weapons; Vol. I: Analysis and Results, Oct. $196 \overline{68}$ (SRD).

W30. P. B. WELLS, E. A. Bathke, D. C. Sachs, AD-399693, Blast and Thermal Environments from Special Weapons; Vol. 1: Analysis and Results, Sept. 1969 (SRD).

W31. P. B. WELLS, E. A. Bathke, D. C. Sachs, AD-399694, Blast and Thermal Environments from Special Weapons; Vol. 2: Air Blast Profile Plots, Sept. 1969 (SRD).

W32. P. B. WELLS, E. A. Bathke, J. R. Keith, D. C. Sachs, AD-518550, Air Blast from Special Weapons in Homogeneous and Non-Homogeneous Atmospheres; Vol. 2: Air Blast Profile Plots, April 1971 (SFRD).

W33. P. B. WELLS, C. E. Horton, E. A. Briggs, D. C. Sachs, AD-531090L, Nuclear Weapons Thermal Radiation Phenomena, Vol. 2: Weapons Test Data Tabulation, Part 1. Operations, July 1974 (SRD).

W34. H. R. WESSON, J. R. Welker, C. M. Sliepcevich, "The Piloted Ignition of Wood by Thermal Radiation," Combustion Flame 16, 303 (1971). 
W35. G. WHITHAM, "A New Approach to Problems of Shock Dynamics," J. Fluid Mech. 2, 145 (1957).

W36. C. K. WIEHLE, AD-474964, Soil-Structure Interaction Under Dynamic Load. Part I: Analysis and Correlation, Nov. 1965.

W37. C. K. WIEHLE, W. L. Durbin, AD-642502, Combined Effects of Nuclear Weapons on NFSS Type Structures, Sept. 1966.

W38. C. K. WIEHLE, AD-622749, Shelter Entranceways and Openings, Sept. 1967.

W39. C. K. WIEHLE, J. L. Bockholt, AD-687293, Existing Structures Evaluation; Part I: Wa1ls, Nov. 1968.

W40. C. K. WIEHLE, J. L. Bockholt, AD-719306, Existing Structures Evaluation; Part IV: Two-Way Action Walls, Sept. 1970.

W41. C. K. WIEHLE, J. L. Bockholt, AD-733343, Existing Structures Evaluation; Part V: Applications, July $19 \overline{71 .}$

W42. C. K. WIEHLE, J. L. Bockholt, AD-738547, Blast Response of Five NFSS Buildings, Oct. 1971 .

W43. C. K. WIEHLE, J. L. Bockholt, AD-768206, Dynamic Analys is of Reinforced Concrete Floor Systems, May 1973.

W44. C. K. WIEHLE, AD-A001387, Dynamic Analysis of a Building and Building Elements, April 1974 .

W45. C. K. WIEHLE, AD-A011134, Evaluation of Existing Structures, Dec. 1974.

W46. C. K. WIEHLE, J. R. Rempe1, J. E. Beck, AD-B034350L, Middle North Series, Dice Throw Event. Dynamic Response of Two Types of German House Construction, Oct. 1978.

W47. S. J. WIERSMA, S. B. Martin, AD-732498, Measurements of the Dynamics of Structural Fires, Aug. 1971.

W48. S. J. WIERSMA, AD-750295, Measurements of the Dynamics of Structural Fires, Aug . 1972.

W49. S. J. WIERSMA, AD-913142L, Middle North Series, Mixed Company Event, Scale Effects in Blast-Fire Interaction, July 1973.

W50. S. J. WIERSMA, S. Martin, AD-779340, Evaluation of the Nuclear Fire Threat to Urban Areas, Sept. 1973.

W51. S. J. WIERSMA, AD-A018798, Characteristics of Fires in Structura1 Debris, Jan. 1975. 
W52. S. J. WIERSMA, S. B. Martin, AD-A018342, The Nuclear Fire Threat to Urban Areas, April 1975.

W5 3. D. W. WILlIAMS, J. S. Adams, J. J. Batten, G. F. Whitty, G. T. Richardson, $\mathrm{AD}-876538$, Operation Euroka: An Australian Mass Fire Experiment, Sept. 1970.

W54. F. A. WILLIAMS, from AD-822599, Three Unconventional Approaches to Experimental Scaling of Mass Fires, Oct. 1967.

W55. F. A. WILLIAMS, "Mechanisms of Fire Spread," 16th Int. Symp. Combustion, 1281 (1976).

W56. R. B. WILlIAMSON, "Fire Performance Under Ful1 Scale Test Conditions--A State Transition Model," 16th Int. Symp. Combustion, 1357 (1976).

W57. K. E. WILLIS, E. R. Brooks, L. J. Dow, AD-403071, Crash Civil Defense Program Study, April 1963.

W58. A. B. WILLOUGHBY, K. Kaplan, AD-083411L, Effects of Topography on Shock Waves in Air, Jan. 1956.

W59. A. B. WILLOUGHBY, K. Kaplan, AD-085378, Effects of Topography on Shock Waves in Air, Feb. 1956 (C-NSI).

W60. A. B. WILLOUGHBY, K. Kaplan, AD-094056L, Effects of Topography on Shock Waves in Air, April 1956.

W61. A. B. WILLOUGHBY, K. Kaplan, R. Condit, BRC, AD-223754L, Effects of Topography on Shock Waves in Air, Aug. 1956.

W62. A. B. WILloUghBY, K. Kaplan, N. R. Wallace, AD-144535, Blast Shielding in Complexes, Aug. 1958.

W63. A. B. WILLOUGHBY, K. Kaplan, J. Zaccor, AD-315611L, Blast Shielding in Complexes. Part II: Megaton Weapons, July 1959.

W64. A. B. WILlOUGHBY, C. Wilton, B. L. Gabrielsen, J. V. Zaccor, AD-693792, A Study of Loading, Structural Response, and Debris Characteristics of Wall Panels, July 1969.

W65. C. C. WILSON, "Commingling of Urban and Forest Fires--A Case Study of the 1970 California Near-Disaster," Fire Research Abstracts and Reviews 13 (1), 35 (1971).

W66. D. M. WILSON, AD-A025765, A Summary of Methods for Computing the Degradation of Structural Elements Due to the Thermal and Therma1-Blast Effect of Nuclear Weapons, March 1976. 
W67. C. WILTON, N. R. Wallace, K. Kaplan, AD-416539, Study of Channeling of Air Blast Waves, June 1963.

W68. C. WILTON, K. Kaplan, N. Wallace, AD-462489, Study of Channeling of Air Blast Waves, Dec. 1964.

W69. C. WILTON, K. Kaplan, AD-A023887, Interim Tests of the Effects of Long Duration Blast-Type Flows on Fires in Urban Interiors and Contents of Emergency Operating Centers (EOC), Jan. 1976.

W70. C. WILTON, K. Kaplan, B. L. Gabrielsen, AD-A055518, The Shock Tunnel: History and Results, Vols. I-V, Feb. 1978.

W71. C. WILTON, D. J. Myronuk, J. V. Zaccor, AD-A105723, Secondary Fire Analysis, Sept. 1981.

W72. L. WILTSHIRE, W. Parker, AD-683307, Ignition of Retardant Treated Cloth by Nuclear Weapon Thermal Pulses, Aug. 1968.

W73. E. F. WITT, AD-A084641, Blast Transport of Debris from Scale Mode1 Buildings, Vol. 1, Jan 1979 .

W74. E. F. WITT, AD-084642, Blast Transport of Debris from Scale Model Buildings, Vol. 2: Appendices, Jan. 1979.

W75. F. A. WODLEY, AD-704145, Pyrolysis Products of Untreated and Flame Retardant Treated Alpha Cellulose and Levoglucosan, Aug. 1969.

W76. J. M. WOLVERTON, AD-094651, Fire Spread in Urban Areas, Tech. Memo PVTM16, Directorate of Inteligence, HQ USAF, Washington, Sept. 1955 (C-NSI).

W77. R. V. H. WOOD, A. C. Werden, R. L. Berg, AD-A073522, Effects of Atomic Weapons on Electric Utilities, June 1965.

W78. M. D. WRIGHT, E. L. Hi11, D. R. Whitaker, AD-742684, Study of Air Distribution in Large Single-Room Shelters, Dec. 1971 .

W79. M. D. WRIGHT, E. L. Hil1, G. M. Botkin, AD-757365, Study of Air Distribution in Large Partitioned Shelters, Feb. 1973.

W80. M. D. WRIGHT, G. M. Botkin, E. L. Hill, AD-785916, Natural Therma1 Ventilation Experimental Studies, Aug. 1974.

W81. M. D. WRIGHT, E. L. Hill, D. F. Tolman, R. O. Lyday, S. B. York, AD-A016026, Rural Area Shelter Development Study, July 1975.

Z01. J. ZACCOR, P. Morris, K. Kaplan, R. Rhoda, AD-501420L, Prediction and Significance of Forest Damage from a 50-Ton H.E. Surface Burst, June 1967 (C-NSI). 
202. J. V. ZACCOR, C. Wilton, G. Shepard, AD-A090135, Industrial Hardening Demonstration, Sept. 1980.

203. J. V. ZACCOR, C. Wilton, R. D. Bernard, AD-A102621, Industrial Hardening: 1980 Technical Report, June 1981.

204. J. V. ZACCOR, H. L. Hsu, C. Wilton, AD-A104869, An Approach to the Management of Hazardous Materials, Sept. 1981.

Z05. Y. ZEL'DOVICH, Y. Raizer, Physics of Shock Waves and High-Temperature Hydrodynamic Phenomena, Vol. 2, Hayes and Probstein, Editors, Academic Press (New York), 1967.

PLS/ jmp/dg 